\title{
IDENTIFICAÇÃO E GRUPAMENTO DAS MADEIRAS SERRADAS EMPREGADAS NA CONSTRUÇÃO CIVIL HABITACIONAL NA CIDADE DE SÃO PAULO
}

\section{GERALDO JOSÉ ZENID}

Biólogo

Orientador: Prof. Dr. JOÃO PERES CHIMELO

Dissertação apresentada à Escola Superior de Agricultura "Luiz de Queiroz", da Universidade de São Paulo, para a obtenção do título de Mestre em Ciências, Área de Concentração: Ciência e Tecnologia de Madeiras.

\author{
PIRACICABA \\ Estado de São Paulo - Brasil \\ Janeiro de 1997
}


Dados Internacionais de Catalogação na Publicação (CIP)

DIVISÃO DE BIBLIOTECA E DOCUMENTAÇÃO - Campus "Luiz de Queiroz"IUSP

\section{Zenid, Geraldo José}

Identificação e grupamento das madeiras serradas empregadas na construção civil habitacional na cidade de São Paulo. / Geraldo José Zenid. - - Piracicaba, 1997. $169 p$.

Dissertação (mestrado) - - Escola Superior de Agricultura Luiz de Queiroz, 1997. Bibliografia.

1. Construção civil 2. Madeira serrada (identificação) 3. São Paulo (cidade) I. Título

CDD 674.2 


\title{
IDENTIFICAÇÃO E GRUPAMENTO DAS MADEIRAS SERRADAS EMPREGADAS NA CONSTRUÇÃO CIVIL HABITACIONAL NA CIDADE DE SÃO PAULO
}

\author{
GERALDO JOSÉ ZENID
}

Aprovada em: 14 de março de 1997

Comissão julgadora:

Prof. Dr. Mário Tomazello Filho

Prof. Dr. Antonio Ludovico Beraldo

Prof. Dr. João Peres Chimelo (orientador)

Prof. Dr. João Peres Chimelo Orientador 
Para

Henriqueta

Luis Fernando e Daniel. 


\section{AGRADECIMENTOS}

Ao Prof. Dr. João Peres Chimelo, meu primeiro professor de identificação de madeiras há 22 anos atrás. Hoje continua me ensinando, sempre com boa vontade e paciência.

Ao Prof. Dr. Marcio Augusto Rabelo Nahuz e ao Prof. Dr. Amantino Ramos de Freitas, respectivamente, atual diretor e ex-diretor da Divisão de Produtos Florestais, do Instituto de Pesquisas Tecnológicas do Estado de São Paulo IPT, pelo apoio e incentivo.

A Fundação Coordenação de Aperfeiçoamento de Pessoal de Nível Superior CAPES, pela concessão da bolsa de estudo que permitiu a execução deste trabalho.

Aos Professores do Curso de Ciência e Tecnologia de Madeiras da ESALQ, pelas informações e orientações prestadas ao longo do curso.

Às empresas distribuidoras de madeiras e às construtoras visitadas, pelas informações e amostras de madeira fornecidas.

À Neusa, Danielle e Gregório, pelo valioso apoio prestado. Suas entrevistas com os distribuidores e construtoras foram fundamentais. Sem elas eu seria jubilado.

Ao Francisco e ao Dr. João, pelo auxílio na identificação botânica das amostras de madeira. 
Aos colegas da Divisão de Produtos Florestais, em especial os do Agrupamento de Propriedades Básicas da Madeira: Nilson, Tadashi, Takashi, Mário, Paulo, Maria Aparecida, Gregório, Francisco, Antônio Carlos, Neusa e Roseana, pelo profissionalismo e dedicação na condução dos trabalhos do Agrupamento. Sem essa atitude não teria sido possivel a conclusão deste estudo.

Às pesquisadoras do Instituto de Botânica, Edenise e Elizabeth Lopes, pela busca de publicações que enriqueceram este trabalho.

A Veronica, ao Flávio Geraldo e ao Antônio Carlos (esteio de muitos mestres e doutores), amigos de longa data, pelas broncas, incentivos (empurrões, na verdade), exemplos etc...

Aos colegas de curso, em especial, Beatriz, Sérgio, Maria José, Inês, Gonzalo, Kátia e Lorena, que, como eu, trabalham, estudam e têm família.

Para nós a conclusão do curso é gloriosa ! 


\section{SUMÁRIO}

Página

LISTA DE FIGURAS............................................................... viii

LISTA DE TABELAS............................................................... ix

RESUMO ................................................................................ xiii

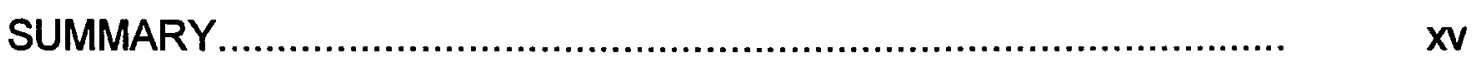

1. INTRODUÇÃO ................................................................ 1

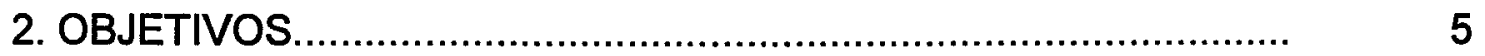

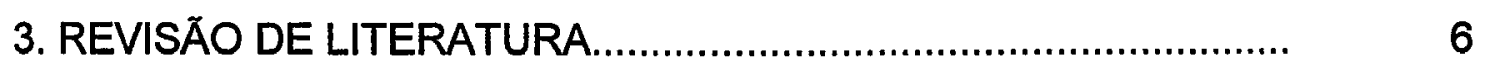

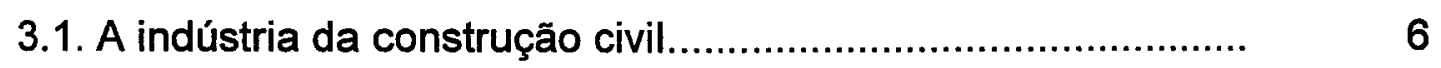

3.2. A madeira na construção civil.............................................. 8

3.3. A produção de madeira serrada........................................... 14

3.3.1. Histórico................................................................. 14

3.3.2. Situação atual e perspectivas..................................... $\quad 20$

3.4. Espécies de madeiras utilizadas........................................ 26

3.5. A identificação de madeiras................................................ 39

3.6. Grupamento de madeiras por uso final................................ 43

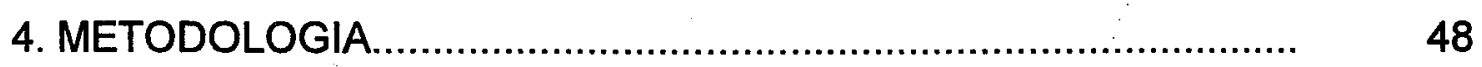

4.1. Pesquisa junto às empresas de distribuição de madeiras e construtoras................................................................ 48

4.1.1. Coleta de informações nas empresas visitadas............ 50

4.2. Identificação botânica das amostras de madeira coletadas.... 52 
Página

4.3. Análise das informações obtidas.......................................... 54

4.3.1. Identificação botânica...............................................

4.3.2. Informações gerais coletadas.................................... $\quad 55$

4.4. Obtenção de informações tecnológicas para as madeiras identificadas

4.5. Critérios para agrupamento das madeiras identificadas de acordo com o uso final na construção habitacional

5. RESULTADOS E DISCUSSÃO.

5.1. Identificação botânica das madeiras que estão sendo

usadas na construção civil habitacional.

5.1.1. Verificação da freqüência de ocorrência das espécies de madeiras identificadas.

5.1.2. Verificação dos nomes comerciais das madeiras usados pelos entrevistados.

5.1.3. Fontes de suprimento.

5.1.4. Problemas com as madeiras

5.2. Informações gerais coletadas nos distribuidores e construtoras.

5.2.1. Padronização das dimensões.

5.2.2. Padronização da qualidade.

5.2.3. Tratamento químico preservante..

5.2.4. Secagem da madeira

5.2.5. Forma de aquisição da madeira.

5.2.6. Critérios para a escolha das espécies de madeira. 
Página

5.3. Agrupamento das madeiras identificadas de acordo com o uso final na construção civil habitacional.

5.3.1. Agrupamento de acordo com as informações fornecidas pelos entrevistados.

5.3.2. Agrupamento de acordo com o critério de classificação proposto.

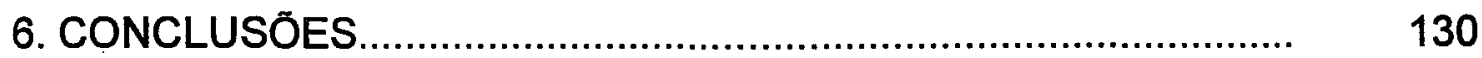

7. REFERÊNCIAS BIBLIOGRÁFICAS....................................... 136

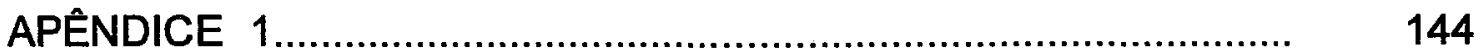

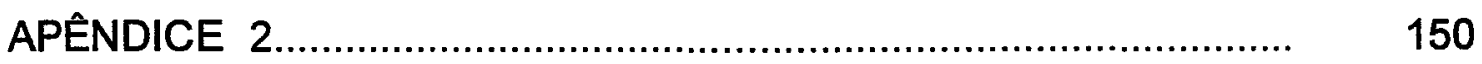

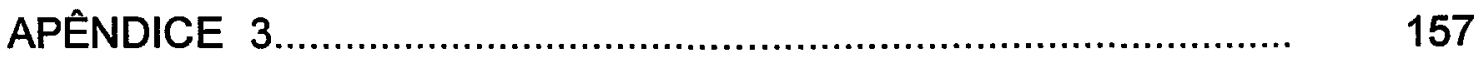

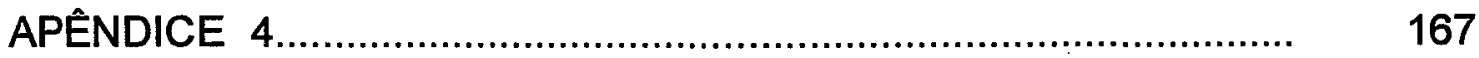




\section{LISTA DE FIGURAS}

Figura

1 Acumulado de espécies em função das visitas realizadas (por seqüência de datas) nos distribuidores $e$ construtoras.....................

2 Acumulado de espécies em função das visitas realizadas (por seqüência de datas) nos distribuidores........................

3 Acumulado de espécies em função das visitas realizadas (por seqüência de datas) nas construtoras........................

4 Freqüência acumulada das madeiras identificadas nos distribuidores, construtoras e no total 


\section{LISTA DE TABELAS}

Tabela

Página

1 Consumo relativo (\%) de produtos de madeira, de acordo com o grau de processamento, nos setores de revenda e engenharia.

2 Participação (\%) de produtos de madeira em relação aos outros insumos comercializados ou utilizados, nos setores de revenda e engenharia.

3 Consumo aparente de madeira serrada.............................

4 Importação e exportação de madeiras, no início deste século.

5 Distribuição do número de serrarias, capacidade instalada e produção de madeira serrada no Brasil, em 1987

6 Distribuição aparente da produção brasileira de madeira serrada em 1989.

7 Agrupamento das espécies de madeira por aplicações construção civil (base ano de 1971).

8 Espécies de madeira utilizadas na construção civil habitacional, na Cidade de São Paulo (base anos de 1974-75).

9 Madeiras amazônicas hierarquizadas por produção, nos estados do Amazonas, Maranhão, Rondônia e Roraima (base: ano de 1984). 
10 Principais espécies de madeiras empregadas em estrutura de cobertura de casas de conjuntos populares localizados no Estado de São Paulo (base: ano de 1987)

11 Espécies de madeiras empregadas, sob diversas formas, nos setores de revenda e construção civil, nas regiões Sul e Sudeste (base: ano de 1988)

12 Espécies de madeiras identificadas em estrutura de cobertura de casas em dois conjuntos populares localizados no interior do Estado de São Paulo (base: ano de 1993).

13 Espécies de madeira identificadas em coleta realizada em dois bairros (Pinheiros e Brás na Cidade de São Paulo (base: ano de 1994)

14 Espécies de madeira identificadas nas amostras coletadas nos distribuidores e construtoras.

15 Familias botânicas e respectiva quantidade de gêneros, das espécies de madeira identificadas.

16 Relação das 10 espécies de madeira com maior freqüência de ocorrência nos distribuidores, construtoras e para o total de amostras coletadas.

17 Verificação do uso de nomes comerciaiṣ pelos entrevistados.

18 Nomes comerciais errados fornecidos pelos distribuidores.

19 Nomes comerciais errados fornecidos pelas construtoras. 
20 Nomes comerciais errados fornecidos pelas construtoras............................................................. 86

21 Fontes de suprimento citadas pelos distribuidores............. 89

22 Fontes de suprimento citadas pelas construtoras............... 90

23 Padronização das dimensões das peças de madeira serrada e beneficiada, nos distribuidores e construtoras....

24 Padronização da qualidade das peças de madeira serrada e beneficiada, nos distribuidores e construtoras..................

25 Tratamento químico preservante das peças de madeira serrada e beneficiada, nos distribuidores e construtoras....

26 Secagem das peças de madeira serrada e beneficiada, nos distribuidores e construtoras

27 Forma de aquisição das peças de madeira serrada e beneficiada, nos distribuidores e construtoras.....................

28 Critérios para a escolha das espécies de madeira que estão sendo utilizadas nas obras visitadas

29 Problemas do setor segundo os distribuidores e construtoras

30 Problemas de comercialização relatados pelos distribuidores e construtoras

31 Problemas de qualidade relatados pelos distribuidores e construtoras

32 Espécies de madeira identificadas pelo IPT, em estruturas de cobertura de casas, e que não foram detectadas neste trabalho. 
33 Agrupamento por uso final, segundo informações dos entrevistados: PESADA INTERNA.

34 Agrupamento por uso final, segundo informações dos entrevistados: LEVE, EM ESQUADRIA.

35 Agrupamento por uso final, segundo informações dos entrevistados: LEVE EXTERNA E INTERNA ESTRUTURAL

36 Agrupamento por uso final, segundo informações dos entrevistados: LEVE INTERNA DECORATIVA.

37 Agrupamento por uso final, segundo informações dos entrevistados: LEVE INTERNA DE UTILIDADE GERAL.....

38 Agrupamento por uso final, segundo informações dos entrevistados: ASSOALHOS DOMÉSTICOS.

39 Agrupamento por uso final, de acordo com o critério de classificação: PESADA INTERNA.....................................

40 Agrupamento por uso final, de acordo com o critério de classificação: LEVE, EM ESQUADRIA

41 Agrupamento por uso final, de acordo com o critério de classificação: LEVE EXTERNA INTERNA ESTRUTURAL

42 Agrupamento por uso final, de acordo com o critério de classificação: LEVE INTERNA DECORATIVA.

43 Agrupamento por uso final, de acordo com o critério de classificação: LEVE INTERNA DE UTILIDADE GERAL......

44 Agrupamento por uso final, de acordo com o critério de classificação: ASSOALHOS DOMÉSTICOS. 


\title{
IDENTIFICAÇÃO E GRUPAMENTO DAS MADEIRAS SERRADAS EMPREGADAS NA CONSTRUÇÃO CIVIL HABITACIONAL NA CIDADE DE SÃo PAULO
}

\author{
Autor: Geraldo José Zenid \\ Orientador: Prof. Dr. João Peres Chimelo
}

\section{RESUMO}

Com o objetivo de contribuir para aumentar e melhorar o uso da madeira serrada na construção civil habitacional, foram identificadas botanicamente e reunidas em grupos de uso final as madeiras que estão sendo comercializadas/utilizadas para esse fim, na Cidade de São Paulo.

Foram visitados 42 distribuidores de madeira e 22 obras de edifícios de vários pavimentos e conjuntos populares, onde foram coletadas 345 amostras de madeira e informações gerais sobre as empresas.

A identificação botânica foi realizada através da anatomia do lenho das amostras coletadas. Foram identificadas 57 espécies de madeira (espécies ou grupos de espécies de difícil distinção na prática), provenientes, principalmente, da Amazônia. Foram identificadas cinco espécies provenientes de reflorestamento: cuningâmia, cupressus, eucalipto, grevílea e pinus.

Tal variedade, reflexo da heterogeneidade das florestas tropicais, não está presente na freqüência percentual de espécies em relação ao total de amostras coletadas, pois somente 15 espécies representaram $80 \%$ da amostras coletadas, dentre estas, espécies tradicionais como: pinho-doparaná, peroba-rosa, ipê e jatobá. Das madeiras de reflorestamento, somente o pinus teve participação importante. 
Diversos erros de identificação foram constatados, principalmente, entre as construtoras. Esses erros ocorreram mais freqüentemente nas madeiras destinadas a usos temporários (andaimes, escoramentos etc.).

Dentre as informações gerais coletadas destacam-se: o setor não utiliza especificações, estabelecidas por entidades normalizadoras, para dimensões e qualidade das peças, o tratamento químico preservante é pouco praticado e há preocupações com relação à secagem da madeira. Os principais problemas apontados pelas empresas estão relacionados à comercialização (alto preço da madeira e do transporte) e à qualidade (deficiência no processamento, defeitos naturais e mistura de espécies).

As madeiras foram reunidas em grupos de usos finais de acordo com as informações dos entrevistados e de acordo com critério proposto no estudo, que está baseado nos níveis das propriedades de madeiras tradicionalmente utilizadas na construção civil habitacional (pinho-doparaná, peroba-rosa e imbuia).

Foi constatada a ausência, total ou parcial, de informações sobre propriedades tecnológicas para diversas madeiras selecionadas para o grupamento por uso final. Também foi observado o uso de diferentes normas de ensaio entre instituições brasileiras que atuam em tecnologia de produtos florestais.

Os agrupamentos realizados mostraram-se mais satisfatórios nos grupos de uso para fins estruturais, onde as propriedades mecânicas são mais importantes, do que naqueles onde a estabilidade dimensional $\mathrm{e} o$ aspecto decorativo, são requisitos básicos. 


\section{IDENTIFICATION AND GROUPING OF SAWNWOOD SPECIES USED FOR HOUSE CONSTRUCTION IN THE CITY OF SÃO PAULO}

Author: Geraldo José Zenid Adviser: Prof. Dr. João Peres Chimelo

\section{SUMMARY}

The sawnwood species commercialized and used for house construction in the City of São Paulo, were botanically identified and grouped according to the end use, in order to contribute to the improvement and the increase of sawnwood in these applications.

Forty two dealers of sawnwood and twenty two building constructors were visited. Three hundred and forty five samples of sawnwood and general information about these companies were collected. The constructions visited included buildings of several floors and low cost houses.

The botanical identification was carried out through the examination of the wood anatomy of the sawnwood samples. This method provided identification of 57 species of wood (species or groups of species not readily separated, in practice). Most of them were from the Amazon Region and five species are from manmade forests: cunninghamia, cupressus, eucalyptus, grevillea and pine.

Such a variety of species, which is typical in tropical forests, was not found when an analysis of the species frequency in relation to the total number of samples was carried out. Only 15 species represented $80 \%$ of the samples collected. Among these, traditional species in the market were identified: Parana pine, red peroba, ipe and jatoba. Pine was the only species from manmade forests found with significant importance in the market. 
Identification mistakes were detected, mainly among building constructors. These mistakes were more common within the sawnwood used for temporary uses.

The general information collected about the market and the utilization of sawnwood in house constructions showed that standardization of dimensions and quality of the pieces, as established by recognized institutions, is not in pratice; the chemical treatment of the wood is rarely done and there are problems with wood drying. The sector's main problems relate to marketing (high costs of wood and transportation) and to quality (processing, natural defects and mix of species).

The species identified were grouped by end uses according to the information collected in interviews and according to the method proposed in this study, which is based on the properties of the well-known species in the market (Parana pine, red peroba and imbuya).

The total or partial lack of information was observed on technological properties for several species studied. Also noticed was the use of different wood testing methods, adopted by Brazilian Research Institutions working with forest products technology.

The species grouping was more effective in structural groups, where mechanical properties are the main requirement, than in groups where the dimensional stability and decorative aspect of wood are the main requirement. 


\section{INTRODUÇÃO}

Os países desenvolvidos estão enfrentando dois desafios que causam impacto nos diversos setores da economia, cujos reflexos já se fazem sentir de forma acentuada em nosso País. Tais desafios dizem respeito à questão ambiental e à competitividade nos setores industriais e de serviços.

Nos últimos 30 anos ocorreu uma mudança no enfoque das questões relacionadas ao desenvolvimento das nações. A crescente consciência dos efeitos ambientais provocados por um desenvolvimento que antagoniza progresso e ambiente, gerou a necessidade de busca de uma forma alternativa, onde o desenvolvimento se processe de forma adequada ao ambiente, atendendo às necessidades atuais sem comprometer o futuro (ELLIOTT, 1990). O fim da era do crescimento-a-qualquer-custo foi colocado para as nações, pelo Banco Mundial, através do Relatório sobre Desenvolvimento e Meio Ambiente (RIBAS, 1992).

Ao mesmo tempo em que a questão ambiental torna-se fundamental no planejamento estratégico de diversos segmentos da economia, surge também a necessidade de se evoluir para a execução de produtos e serviços competitivos. Tal mudança de postura tem sido realçada no Brasil, tanto pela formação dos grandes blocos econômicos na Europa e na América do Norte, que afetam as exportações brasileiras, como também pela crescente exposição do nosso mercado interno à competição internacional.

Os elementos centrais da competitividade são a qualidade e a produtividade. Produzir com qualidade significa gerar produtos e serviços 
de acordo com as especificações e totalmente orientados para as necessidades dos clientes.

$\mathrm{Na}$ exposição de motivos do Programa Brasileiro da Qualidade e Produtividade, lançado pelo governo federal em 1990, afirma-se que a preocupação com a qualidade ainda é incipiente em nosso País e que as perdas por falta de qualidade podem atingir até $40 \%$ do produto industrial. Essas perdas acarretam produtos mais caros, e eqüivalem a dezenas de bilhões de dólares, podendo alcançar cifras ainda mais dramáticas na área de serviços.

Estima-se que, na construção civil habitacional, os desperdícios com materiais cheguem a $20 \%$ do total necessário para a execução da obra, estando a madeira entre esses materiais (RODRIGUES, 1992).

A madeira é um material utilizado pelo homem desde os tempos pré-históricos, para obtenção de energia, confecção de utensílios, armas, abrigos etc.

Em todo o desenvolvimento da humanidade a madeira contribuiu de forma decisiva nos diversos avanços alcançados pelo homem, como na construção dos navios, que permitiram a expansão da civilização européia, e na fabricação de papel, condição importante na divulgação abrangente de conhecimentos adquiridos.

Mesmo nos dias atuais, onde o desenvolvimento da ciência e da tecnologia propiciam o surgimento de materiais sofisticados e de alto desempenho - os chamados novos materiais, que permitem ao homem executar tarefas antes consideradas impossiveis, a madeira ainda desempenha um papel muito importante em vários segmentos econômicos, como os da construção civil e do mobiliário.

A madeira possui diversas propriedades, que a tornam muito atraente frente a outros materiais. Dentre essas, são comumente citados, 
o baixo consumo de energia para seu processamento, a alta resistência específica, as boas características de isolamento térmico e elétrico, além de ser um material muito fácil de ser trabalhado manualmente ou por máquinas (PANSHIN \& DE ZEEUW, 1970; FUNNELL, 1978 e FREITAS, 1982).

$O$ aspecto, no entanto, que distingue a madeira dos demais materiais é a sua renovabilidade, consubstanciada na possibilidade crescente de viabilização técnico-econômica da produção sustentada das florestas nativas e nas modernas técnicas silviculturais empregadas nos reflorestamentos, que permitem alterar a qualidade da matéria-prima de acordo com o uso final desejado.

O fato da madeira ser o resultado do crescimento de um ser vivo, implica em variações das suas características em função do meio ambiente em que a árvore se desenvolve. A esta variabilidade acrescenta-se que a madeira é produzida por diferentes espécies de árvores, cada qual com características anatômicas, físicas e químicas próprias (PANSHIN \& DE ZEEUW, 1970).

A madeira é um material higroscópico, sendo que várias de suas propriedades são afetadas pelo teor de água presente. Sua natureza biológica, submete-a aos diversos mecanismos de deterioração existentes na natureza. A essas características negativas acrescenta-se sua susceptibilidade ao fogo. Essas desvantagens da madeira podem ser eliminadas ou, ao menos, minimizadas, bastando para tal o emprego de tecnologias já disponíveis e de uso consagrado nos países desenvolvidos.

No entanto, o desconhecimento das propriedades da madeira por muitos de seus usuários e a insistência em métodos de construção antiquados, são as maiores causas de desempenho insatisfatório da madeira frente a outros materiais (PANSHIN \& DE ZEEUW, 1970).

No Brasil, existe um preconceito generalizado em relação a um uso mais intensivo da madeira na construção civil de edificações para fins 
habitacionais. Esse preconceito está baseado no uso indevido da madeira e na tradição herdada dos colonizadores espanhóis e portugueses (FREITAS, 1982 e PEREZ \& KAMAZOE, 1988).

Atualmente a madeira é empregada na construção habitacional, de forma temporária, na instalação do canteiro de obras, nos andaimes, nos escoramentos e nas fôrmas. De forma definitiva, é utilizada nas esquadrias, nas estruturas de cobertura, nos forros e nos pisos (FARAH, 1992).

Os principais centros demandantes de madeira serrada, localizados nas Regiões Sul e Sudeste, têm experimentado uma mudança nas fontes de suprimento de madeira. Com a exaustão das florestas nativas dessas regiōes, o suprimento de madeiras nativas passou a ser realizado, em parte, a partir de países limítrofes como do Paraguai e, mais recentemente, da Bolívia, porém, de forma mais significativa a partir da região amazônica. As madeiras disponíveis nos reflorestamentos implantados nas Regiōes Sul e Sudeste, com pinus (Pinus spp) e eucalipto (Eucalyptus spp) já começaram também a suprir a construção habitacional. Essas mudanças têm provocado a substituição do pinho-do-paraná (Araucaria angustifolia (Bert.) O. Kuntze.) e da peroba-rosa (Aspidosperma polyneuron Muell. Arg.) por outras madeiras desconhecidas dos usuários e, às vezes, inadequadas ao uso pretendido. 


\section{OBJETIVOS}

O presente estudo, diante do que foi exposto anteriormente, tem como objetivo geral apresentar uma contribuição para o uso mais eficiente da madeira serrada, proveniente de florestas nativas ou de reflorestamentos, na construção civil de edificações para fins habitacionais.

Nesse contexto, o estudo pretende atingir os objetivos específicos relatados a seguir.

- Identificar as madeiras serradas que estão sendo empregadas na construção de habitações na Cidade de São Paulo.

- Elaborar um critério técnico para alocar madeiras em grupos de uso final para a construção habitacional.

- Agrupar as madeiras identificadas por grupos de usos finais, de acordo com: informações coletadas junto às empresas do setor madeireiro e segundo o critério de classificação elaborado no estudo.

- Relatar informações, colhidas junto às empresas visitadas, sobre as madeiras identificadas, tais como: nomes comerciais utilizados, fontes de suprimento, dimensões e qualidade das peças, uso final, desempenho em uso e características indesejáveis da madeira, que estejam dificultando sua comercialização ou uso na construção civil habitacional. 


\section{REVISÃO DE LITERATURA}

\subsection{A indústria da construção civil}

De acordo com FARAH (1992), a indústria da construção civil exerce importante papel na economia brasileira, não só pelo suporte que fornece a outros setores da economia, como também pela sua contribuição na geração do Produto Interno Bruto - PIB.

FARAH (1992) menciona que a indústria da construção civil gerou a infra-estrutura necessária para os diversos planos de desenvolvimento lançados no Brasil após o final da Segunda Guerra. Segundo a mesma autora, o setor também é responsável pela construção de equipamentos e edificações ligados às atividades de produção (indústrias), de comércio (centros comerciais) e de reprodução da força de trabalho (hospitais, escolas e habitações).

Dados do IBGE (1990)' ${ }^{1}$, citados por FARAH (1992), mostram que no período de 1970 a 1988, a indústria da construção civil contribuiu para o PIB com valores percentuais entre 5,13 e 7,32. Ainda, segundo a mesma fonte, em 1988 o setor gerou produtos equivalentes a $18,1 \%$ do PIB do setor industrial. Se a este valor, for agregado o produto dos setores de produção de materiais e componentes de construção, a participação aumenta para $30 \%$, segundo estimativa do Sindicato da Indústria da

${ }^{1}$ ANUÁRIO ESTATÍSTICO DO BRASIL - 1990. Fundação Instituto Brasileiro de Geografia e Estatística - IBGE. Rio de Janeiro, IBGE, 1990. Cap. 49 Contas Nacionais. Quadros 13 e 14, p. 566 - 567. 
Construção Civil de Grandes Estruturas no Estado de São Paulo SINDUSCON ${ }^{2}$, mencionada por FARAH (1992).

Outro dado importante do setor refere-se à mão-de-obra ocupada. Segundo o IBGE (1987) ${ }^{3}$, citado por FARAH (1992), em 1989 o setor empregou 3,8 milhões de trabalhadores, o que representa $6,2 \%$ da mão-deobra ocupada no Brasil e $26,3 \%$ da mão-de-obra industrial.

Esses dados apresentados dizem respeito à indústria da construção civil como um todo. O setor, no entanto, é formado pelos segmentos: construção pesada, montagem industrial e edificações, segundo a FUNDAÇÃO JOÃO PINHEIRO $(1984)^{4}$, citado por FARAH (1992).

O segmento de edificações engloba atividades de construção de edifícios para fins residenciais, comerciais, industriais e institucionais; construção de conjuntos habitacionais; realização de partes de obras, como fundações, estruturas e reformas (FARAH, 1992).

$\mathrm{Na}$ construção de edificaçōes para fins habitacionais, objeto deste estudo, a produção informal tem prevalecido sobre a construção industrial. No entanto, a participação desta tem sido significativa, principalmente nas últimas décadas, no âmbito do Sistema Financeiro da Habitação - SFH, onde mais de $90 \%$ das moradias foram construidas por construtoras (FARAH, 1992).

O potencial de desenvolvimento para o setor é amplo. Previsões realizadas para o período 1985-90, segundo a FUNDAÇÃO JOÃO PINHEIRO $(1984)^{4}$, citado por FARAH (1992), estimaram serem necessárias a

2 SINDUSCON. Altos e baixos da construção. Dirigente construtor. São Paulo, 26(10): 16 - 22, out. 1990.

${ }^{3}$ IBGE. Estatísticas históricas do Brasil. Rio de Janeiro, IBGE, 1987. População economicamente ativa. P. 73. (Séries Estatísticas Retrospectivas, v. 3).

${ }^{4}$ FUNDAÇÃO JOÃO PINHEIRO. Diagnóstico nacional da indústria da construção. Belo Horizonte, F.J.P., 1984, v.1 Relatório Síntese. P.11 a 29. 
construção de 1,3 milhão de moradias por ano, para suprir a demanda representada pelo crescimento demográfico e pelas necessidades de reposição e substituição de moradias. Em 1993, o déficit habitacional era estimado em quatro milhões de unidades (MENGEL, 1993).

Ao lado dessa demanda potencial quantitativa, FARAH (1992) aponta uma demanda qualitativa caracterizada pelas crescentes tensões sociais decorrentes do déficit habitacional nos centros urbanos.

\subsection{A madeira na construção civil}

A construção civil habitacional è considerada como o principal mercado para os produtos da indústria madeireira, tanto em países desenvolvidos, como naqueles em processo de desenvolvimento. Isto ocorre não só em termos quantitativos, como também pela oportunidade de uso de uma grande variedade de produtos à base de madeira (NAHUZ, 1978; RIVOLI et alii, 1978; KEENAM \& TEJADA, 1984).

Os diversos produtos à base de madeira podem ser reunidos em dois grupos: a madeira serrada e os painéis. O primeiro grupo engloba a madeira simplesmente serrada e a beneficiada (aplainada, emoldurada etc.), com dimensões variadas. O grupo de painéis inclui os compensados laminados e sarrafeados, as chapas de fibra e os aglomerados (NAHUZ, 1978).

RIVOLI et alii (1978) mencionam que no período de 1967 a 1969, a construção habitacional foi responsável, a nível mundial, pelo consumo de $44 \%$ da produção de madeira serrada, de $44 \%$ da produção de painéis de madeira compensada e de $4 \%$ da produção de outros tipos de painéis.

Para o Brasil, RIVOLI et alii (1978) apontam para o ano de 1974, uma demanda pela construção civil de $30 \%$ da produção de madeira 
serrada $\left(2,74\right.$ milhões de $\left.\mathrm{m}^{3}\right), 43 \%$ da produção de painéis de madeira compensada e de $3 \%$ de outros tipos de painéis. Esses autores detectaram no Brasil, a exemplo do que ocorre nos países desenvolvidos, a tendência de substituição da madeira serrada pelos painéis, principalmente os de madeira compensada.

A ASSOCIAÇÃO BRASILEIRA DE PRODUTORES DE MADEIRAS - ABPM (1989a), em pesquisa realizada nos estados de São Paulo, Rio de Janeiro, Paraná, Santa Catarina e Rio Grande do Sul, junto aos setores de engenharia (construção civil) e de revenda (construção civil e marcenaria), detectou o consumo relativo de produtos de madeira, de acordo com o grau de processamento, apresentado na Tabela 1.

Tabela 1 - Consumo relativo (\%) de produtos de madeira, de acordo com o grau de processamento, nos setores de revenda e engenharia.

\begin{tabular}{lcc}
\hline \multicolumn{1}{c}{ Grau de processamento } & \multicolumn{2}{c}{ Setor } \\
& revenda & engenharia \\
\hline & 62,3 & 69,4 \\
madeira serrada & 14,8 & 2,5 \\
porta, batentes etc. & 14,2 & 23,1 \\
compensados laminados & 4,1 & 2,1 \\
compensados sarrafeados & 3,0 & 1,6 \\
laminados & 0,5 & 0,6 \\
aglomerados & 1,1 & 0,7 \\
chapas de fibra & & \\
\hline
\end{tabular}

Fonte: ABPM (1989a)

Nessa mesma Tabela observa-se que, a despeito da tendência apontada por RIVOLI et alii (1978), o consumo de madeira serrada 
ainda é bem superior ao de painéis, tanto no setor de revenda como no de engenharia.

Na Tabela 2 apresenta-se a participação da madeira em relação ao consumo total de materiais comercializados pelo setor de revendas, e em relação aos insumos totais empregados pelo setor de engenharia, segundo dados da ABPM (1989a).

Tabela 2 - Participação (\%) de produtos de madeira em relação aos outros insumos comercializados ou utilizados, nos setores de revenda e engenharia.

\begin{tabular}{ccc}
\hline $\begin{array}{c}\text { Faixas } \\
(\%)\end{array}$ & revenda & engenharia \\
\hline & & \\
10 a 20 & 27,8 & 72,7 \\
20 a 40 & 14,8 & 12,1 \\
40 a 60 & 9,3 & 3,0 \\
60 a 80 & 11,1 & 3,0 \\
80 a 100 & 37,0 & 9,2 \\
participação ponderada & 54,4 & 26,3 \\
& & \\
\hline
\end{tabular}

Fonte: ABPM (1989a)

Nessa Tabela observa-se que, no setor de revendas, a madeira tem uma participação ponderada de $54,4 \%$ em relação ao total de materiais comercializados. Na desagregação da participação em faixas de consumo, observa-se uma concentração maior na faixa de 80 a 100\% seguida pela faixa de 10 a $20 \%$, refletindo diferentes graus de especialização das lojas. 
Já para o setor de engenharia, verifica-se na Tabela 2 uma concentração do consumo de madeira na faixa de 10 a $20 \%$ do consumo total de materiais empregados pelo setor, sendo a participação média ponderada de $26,3 \%$.

RIVOLI et alii (1978) relatam os seguintes empregos da madeira na construção civil: fôrmas de concreto, uso auxiliar ou temporário (tapumes, barracos e andaimes), estrutura para telhados, forros, portas de apartamento e de edifícios, janelas, escurecedores de ambiente (venezianas), lambris e painéis decorativos, armários, pisos etc. Nesses usos, os autores mencionam que a madeira serrada sofre a competição de outros materiais, sendo o emprego em usos temporários, estruturas para telhados, portas e pisos, aqueles em que a madeira mais se destaca.

FARAH (1992) aponta o uso da madeira nas seguintes fases da construção: instalação do canteiro de obras e na execução das esquadrias (janelas, portas etc.), da cobertura (estrutura de telhado), do forro e do piso.

No Brasil, entretanto, a madeira ainda é um material pouco utilizado na indústria de construção civil. Na Tabela 3 (página 12), observa-se que neste País o consumo aparente "per capita" de madeira serrada é inferior ao do Japão, que é detentor de poucos recursos florestais comercialmente exploráveis (FREITAS, 1988).

Segundo FREITAS (1978), nos Estados Unidos e Canadá, cerca de $90 \%$ das construções habitacionais unifamiliares são executadas em madeira, enquanto que no Brasil esse número é inferior a $2 \%$.

Segundo UNIDO (1983) vários fatores restringem o uso da madeira na construção de habitações nos países em desenvolvimento, com destaque, porém, para as limitações legislativas e financeiras, ao lado da resistência da população ao uso de casas de madeira (relativo à deterioração e 
ao risco de incêndio), falta de disseminação de informações tecnológicas e inexperiência do setor produtivo.

Tabela 3 - Consumo aparente de madeira serrada.

\begin{tabular}{|c|c|c|c|}
\hline \multirow[b]{2}{*}{ País } & \multirow{2}{*}{$\begin{array}{l}\text { População } \\
\text { (10 } 10^{6} \text { hab.) }\end{array}$} & \multicolumn{2}{|c|}{ Consumo aparente } \\
\hline & & $\begin{array}{c}\text { total } \\
\left(10^{3} \mathrm{~m}^{3}\right)\end{array}$ & $\begin{array}{l}\text { per cap } \\
\left(\mathrm{m}^{3} / \mathrm{ha}\right.\end{array}$ \\
\hline Brasil & 135 & 15.665 & 0,116 \\
\hline Canadá & 25 & 13.691 & 0,54 \\
\hline França & 55 & 10.349 & 0,18 \\
\hline Estados Unidos & 230 & 114.274 & 0,497 \\
\hline Japão & 120 & 33.062 & 0,27 \\
\hline Suécia & 8,5 & 4.104 & $0,4 \varepsilon$ \\
\hline
\end{tabular}

\section{Fonte: FREITAS (1988)}

${ }^{1}$ Consumo aparente $=$ produção + importação - exportação

A baixa utilização de madeiras na construção habitacional, no Brasil e nos demais países da América Latina, é explicada basicamente pela tradição herdada dos colonizadores, espanhóis e portugueses, que empregavam pouca madeira em suas construções, privilegiando pedras, tijolos e argamassa para pisos e paredes (FREITAS, 1978; KEENAN \& TEJADA, 1984; PEREZ \& KAMAZOE, 1988 e WOLFE, 1991).

A madeira, na forma de vigas e caibros, somente era empregada nas estruturas de cobertura. Essa tradição, possivelmente fruto da disponibilidade e durabilidade dos materiais nos locais de origem dos 
colonizadores, levou a uma rápida aceitação do concreto e a uma atitude negativa em relação à madeira (WOLFE, 1991).

Corroborando esse fato, FREITAS (1978) menciona que no Sul do Brasil, onde há uma influência marcante de imigrantes alemães e poloneses, o uso da madeira na construção habitacional é intenso e freqüente. PEREZ \& KAMAZOE (1988) mencionam também a existência de tradições regionais, como no estado do Amazonas, onde $72 \%$ das casas são construídas em madeira.

KEENAN \& TEJADA (1984) mencionam a pouca disponibilidade de engenheiros, arquitetos e construtores bem treinados no uso da madeira em construções. Segundo esses autores, há ausência de ações firmes por parte dos governos, agências financiadoras e da indústria de produtos florestais, em direção da criação de uma infra-estrutura que permita o uso racional da madeira na construção de habitaçōes nos países latinoamericanos.

Para PEREZ \& KAMAZOE (1988) o preconceito em relação ao uso de madeira na construção de habitações, tanto pelo usuário como pelos agentes financeiros, está fundamentado no uso inadequado da madeira devido a problemas, dentre outros, de secagem e de deterioração, que são realçados em ambientes tropicais, como também com os problemas de segurança contra incêndios.

FREITAS (1988) cita que a falta de conhecimentos tecnológicos sobre a madeira se deve à pouca ênfase dada à madeira nos currículos das escolas de engenharia e arquitetura, em relação aos outros materiais, como aço e concreto. Como resultado, a madeira é preterida em muitas situações em que teria um desempenho superior a outros materiais, ou ainda, é mal empregada, resultando em desempenho ruim e reforçando o preconceito. Cita também a precariedade do setor produtivo (serrarias), que exerce uma atividade mais de fundo extrativista do que industrial. 
Adicionalmente, FREITAS (1988) e UNIDO (1983) apontam para a ausência de normas técnicas para distribuição das peças de madeira serrada em classes de qualidade, em função da presença de defeitos, bem como para a heterogeneidade das florestas tropicais, que dificulta a sua exploração econômica.

Para WOLFE (1991) a opinião tradicionalmente negativa sobre a madeira na América Latina, não motiva os engenheiros, arquitetos, técnicos e construtores ligados à construção civil a desenvolver expertise em projetos e construções com madeiras. Segundo o mesmo autor, essa postura também se reflete nos poucos cuidados despendidos com 0 manejo e exploração das florestas e na produção de madeira serrada.

Embora exista disponibilidade de instituições de pesquisas com equipamentos e pessoal treinado, WOLFE (1991) menciona a deficiência na transferência de tecnologia e na disponibilidade de fundos para execução de trabalhos, como fatores limitantes. O autor afirma que há um gap entre o que se conhece e o que é praticado.

Para KEENAN \& TEJADA (1984), ironicamente o preconceito contra a madeira ocorre numa região de abundância dessa matéria-prima renovável, onde há déficit crônico de habitações adequadas.

\subsection{A produção de madeira serrada}

\subsubsection{Histórico}

A utilização de produtos florestais no Brasil, começou com a exploração do pau-brasil (Caesalpinia echinata Lam.) e constituiu-se no primeiro ciclo econômico do Brasil colônia (FREITAS, 1978).

Segundo AZEREDO (1987), já na Carta Régia de 1797, o governo imperial regulou a exploração e exportação de madeiras para 
construção, que poderiam ser de maior interesse para a Marinha Real e para a Fazenda. Ainda, segundo o mesmo autor, em 1817 foi disciplinado o corte de pau-brasil e, em anos subseqüentes, diversas decisões e leis referentes ao corte, ao armazenamento e à exportação de madeiras para a Europa, foram promulgadas.

ANDRADE (1923) afirma que, no inicio do século passado, a madeira não estava entre os principais produtos exportados pelo País e que o pau-brasil era a única espécie que contribuía com volumes regulares. Este autor menciona que essa pequena participação persistiu ao longo de todo o século passado e ilustra com valores de 2673 toneladas para 1839 e 1840 , e de 28636 toneladas para 1871 e 1872.

Foi na segunda metade do século passado, com o estabelecimento de colonos europeus em Santa Catarina, Rio Grande do Sul e, posteriormente, no Paraná, que se iniciou o processo de exploração das extensas reservas de pinho-do-paraná (Araucaria angustifolia (Bert.) 0 . Kuntze.), e que marcou o surgimento da indústria de madeira serrada brasileira (AZEREDO, 1987).

Os primeiros colonos ocuparam as terras para praticar agricultura de subsistência e empregaram o pinho-do-paraná, obtido de forma primitiva através de traçadores e machados, para construção de suas casas (AZEREDO, 1987). Muitos desses colonos passaram a agregar renda à atividade agrícola, com a produção e comércio de madeira serrada obtida em pequenas serrarias (AZEREDO, 1987).

WATSON (1980) relata que a madeira de pinho-doparaná e o mate (Ilex paraguariensis St. Hil.) formaram a base do segundo e do terceiro ciclos econômicos do Paraná durante o século passado e o início deste. O referido autor relata, ainda, que com a construção da rodovia Graciosa, em 1873, e da ferrovia Curitiba - Paranaguá, entre 1880-84, foi 
criada a infra-estrutura para a exportação do grandioso recurso florestal do Estado do Paraná.

A industrialização da madeira foi se desenvolvendo gradativamente. As primeiras serrarias operavam com serras de centro; posteriormente foram utilizadas serras francesas, até aparecerem as serras de fitas importadas (AZEREDO, 1987).

MAEGLIN (1991) menciona que, na América Latina, as primeiras operações de serrarias foram realizadas por serrarias pequenas $e$, em grande parte, móveis. Segundo esse autor, grandes serrarias (serrarias industriais) eram raras antes da $1^{\text {a }}$ Guerra Mundial e, paradoxalmente, muitas das maiores e melhores serrarias foram construídas para atender mercados de exportação ao invés de cobrir as necessidades regionais, o que em muitos lugares era feito através da importação de mercadorias .

A primeira década deste século assinalou o rápido desenvolvimento das cidades do Rio de Janeiro e São Paulo (ABRIL CULTURAL, 1985 e FARAH, 1992) com o conseqüente aumento na demanda por materiais de construção.

A despeito da disponibilidade de grandes reservas florestais e do inicio da produção de madeira serrada de pinho, as duas primeiras décadas deste século foram marcadas pela importação significativa de madeiras serradas e beneficiadas, do hemisfério norte, para atender à demanda das cidades do Rio de Janeiro e São Paulo (BELLO \& SILVA, 1908; PEREIRA, 1914 e ANDRADE, 1923).

PEREIRA (1914) constatou, ao elaborar a $5^{a}$ edição de seu trabalho, que a situação de uso das madeiras brasileiras tinha se alterado muito pouco em relação ao ano de publicação da primeira edição em 1905 . O autor revela o dispêndio de milhares de contos de réis com a importação de madeiras brutas e manufaturadas, enquanto "...as nossas mais preciosas essências tendem a desaparecer, malbaratadas e mal empregadas...". 
PEREIRA (1914) atribuia essa situação à falta de estudos para aproveitamento econômico da flora brasileira.

BELLO \& SILVA (1908) comentam sobre a abundância das florestas brasileiras e "...entretanto - triste é dizel-o - vamos comprar o pinho americano para construir nossas casas, olvidando nas quebradas da serra nossas madeiras, que não têm rivaes...". Esse autores atribuiam a pouca competitividade das madeiras brasileiras, às dificuldades de extração (tamanho das toras e caminhos acidentados), à falta de conhecimento sobre as madeiras e aos altos fretes ferroviários. Criticaram também 0 desperdício das derrubadas, seguidas de queimadas.

BELLO \& SILVA (1908) ao discorrerem sobre a peroba (Aspidosperma spp) comparam-na com o carvalho europeu (Quercus spp) e citam a grande disponibilidade nos estados de São Paulo, Minas Gerais, Rio de Janeiro e Espírito Santo, porém, com preço não remunerador frente à concorrência do pinho-americano.

Sobre o pinho-do-paraná, BELLO \& SILVA (1908) apontam a potencialidade dessa madeira como substituta do pinho-americano. Mencionam que, a despeito das medidas protetoras, o pinho-americano foi imbatível até 1905, em razão da baixa capitalização das empresas brasileiras. Sobre os pinheirais de São Paulo, Minas Gerais e Rio Grande do Sul, os autores mencionam a pouca exploração dos mesmos e que esses estados importavam madeiras estrangeiras ou o pinho-do-paraná de outros locais.

ANDRADE (1923) aponta a grande heterogeneidade das florestas brasileiras como a razão da menor competitividade de nossas madeiras frente às madeiras estrangeiras e complementa "... e para que as essências indígenas pudessem concorrer com o pinho de Riga e o choupo da Rússia foi preciso taxal-os com pesadíssimos impostos, systema, aliás, communissimo neste paiz essencialmente agricola, paraiso de industriaes protegidos...". 
Tabela 4 - Importação e exportação de madeiras, no início deste século.

\begin{tabular}{ccc}
\hline Ano & $\begin{array}{c}\text { Importação } \\
(t)\end{array}$ & $\begin{array}{c}\text { Exportação } \\
(t)\end{array}$ \\
1902 & nd $^{1}$ & 6.628 \\
1910 & nd & 7.448 \\
1911 & 98.821 & nd \\
1912 & 143.364 & nd \\
1913 & 169.638 & 20.310 \\
1914 & 55.461 & nd \\
1915 & 37.366 & 38.374 \\
1916 & 16.612 & 82.816 \\
1917 & 11.217 & nd \\
1918 & 18.071 & nd \\
1919 & 10.905 & nd \\
1920 & 38.172 & 125.394 \\
1921 & 14.817 & 100.499 \\
$1922{ }^{2}$ & nd & 117.911 \\
& & \\
\hline
\end{tabular}

Fonte: ANDRADE (1923)

${ }^{1}$ nd = não disponível

${ }^{2}$ dados referentes a 11 meses

A Tabela 4 mostra o volume de madeira importado e exportado pelo Brasil, no período de 1902 a 1922. Nesta Tabela, observa-se o declínio das importações e o crescimento das exportações de madeiras, nas primeiras décadas deste século. ANDRADE (1923) explica essa situação, pelas medidas protecionista (taxação da importação) e de incentivo ao uso de 
madeiras brasileiras adotadas pelo governo e pela deflagração do $1^{0}$ conflito mundial.

Segundo MAEGLIN (1991), o Brasil começou a exportar o pinho-do-paraná por volta do início da $1^{\text {a }}$ Guerra Mundial, quando a companhia "Southern Brazil Lumber and Colonization Company" construiu a mais moderna serraria de então, no estado de Santa Catarina.

O pinho-do-paraná foi conquistando definitivamente 0 mercado interno e passou a comandar as exportações brasileiras de madeira serrada, de forma tal que, em 1941, o Governo Federal criou o Instituto Nacional do Pinho, com o intuito de regularizar e desenvolver a exploração dos pinheirais (AZEREDO, 1987 e ABPM, 1989b).

Nas décadas de 50 e 60 a Região Sul dominou a produção brasileira de madeira serrada, tendo atingido o auge de produção nos anos de 1975 e de 1976, para, então, entrar em franco declínio de produção em razão da exaustão de suas reservas (AZEREDO, 1987).

Nas décadas de 60 e 70 ocorreram mudanças significativas que alteraram profundamente o panorama florestal brasileiro (AZEREDO, 1987; ABPM, 1989b; TEREZO, 1990 e Sociedade Brasileira de Silvicultura - SBS, 1990).

Em 1965 foi criado o Instituto Brasileiro de Desenvolvimento Florestal - IBDF. Já no ano seguinte, este órgão encetou o programa de incentivos fiscais para reflorestamento, que atingiu ao final de 20 , anos a marca excepcional de 6,2 milhões de ha de projetos aprovados, sendo $52 \%$ com eucalipto (Eucalyptus spp) e $30 \%$ com pinus (Pinus spp) (ABPM, $1989 b$ e SBS, 1990).

$\mathrm{Na}$ década de 60 e, mais intensivamente, na década de 70, o governo brasileiro promoveu a colonização da Amazônia, construindo uma infra-estrutura de estradas que permitiu o acesso às florestas densas de 
terra-firme. A conseqüência imediata dessa ocupação foi o aumento drástico da oferta de matéria-prima florestal na região (TEREZO, 1990).

TEREZO (1990) menciona que essa situação gerou um enorme desperdício de matéria-prima e provocou mudanças drásticas no perfil da indústria de madeira serrada da região. $O$ número de serrarias foi significativamente aumentado - de 89 serrarias existentes em 1953, passou-se para 1797, em 1982. Além dessa mudança, segundo o mesmo autor, as serrarias deslocaram-se das áreas ribeirinhas - onde se abasteciam de toras extraídas da floresta de várzea - para regiões mais centrais da Amazônia.

Nesse quadro de aumento de matéria-prima florestal nativa na Região Amazônica e de escassez na Região Sul, houve a migração de muitas serrarias desta, para aquela região e, também, para países limítrofes, como Paraguai e Bolívia (SBS, s.d.).

Por último, AZEREDO (1987), assinala a tendência de retomada de produção de madeira serrada na Regiāo Sul ao final da década de 70 e início dos anos 80 , com a entrada da matéria-prima oriunda dos reflorestamentos realizados com pinus (Pinus spp).

\subsubsection{Situação atual e perspectivas}

As informações estatísticas sobre o setor de madeira serrada no Brasil são escassas e pouco consistentes, o que dificulta a elaboração de um perfil desse setor (AZEREDO, 1987; SUCHEK, 1989; ABPM, 1989 b e SBS, s.d..).

SUCHEK (1989) estimou, para o ano de 1986, um Produto Interno Bruto - PIB do setor florestal da ordem de 6,91 bilhões de dólares, correspondente à $2,37 \%$ do PIB brasileiro. Ainda, segundo esse autor, o subsetor indústria de madeira serrada contribuiu com 15 milhões de $\mathrm{m}^{3}$, equivalentes a 2,25 bilhões de dólares, ou seja, $32,56 \%$ do total. Tal 
participação só é inferior à do sub-setor celulose e papel, que contribuiu com $39,51 \%$ do total gerado pelo setor florestal.

Na Tabela 5 são apresentados o número de serrarias, a capacidade instalada e a produção de madeira serrada no Brasil, no ano de 1987, desagregada nas regiões Amazônica e Sul/Sudeste, conforme TEREZO (1990) e SBS (s.d.). De acordo com esses dados, a Região Amazônica concentra 89,5 e $87,5 \%$, respectivamente, da capacidade instalada e da produção de madeira serrada no Brasil.

Tabela 5 - Distribuição do número de serrarias, capacidade instalada e produção de madeira serrada no Brasil, em 1987.

\begin{tabular}{lcrrrr}
\hline Região & $\begin{array}{c}\text { Serrarias } \\
\left(\mathrm{n}^{\circ}\right)\end{array}$ & \multicolumn{2}{c}{ Capacidade instalada } & \multicolumn{2}{c}{ Produção } \\
& & $\left(\mathrm{Mm}^{3}\right)^{1}$ & $(\%)$ & $\left(\mathrm{Mm}^{3}\right)$ & $(\%)$ \\
\hline Amazônica $^{2}$ & 2982 & 24,450 & 89,5 & 14,695 & 87,5 \\
Sul / Sudeste $^{3}$ & $\mathrm{nd}^{4}$ & 2,865 & 10,5 & 2,095 & 12,5 \\
TOTAL & & 27,315 & 100,0 & 16,790 & 100,0
\end{tabular}

\footnotetext{
Fontes: ${ }^{2}$ TEREZO (1990)

${ }^{3}$ SBS (s.d.)

${ }^{1} \mathrm{Mm}^{3}$ = mega metro cúbico

${ }^{4}$ nd = não disponível
}

Estimativas para o ano de 1989 (ABPM, 1989b), revelaram um número de 8000 serrarias em operação no Brasil, com uma capacidade instalada e uma produção anuais de, respectivamente, 20 e 15 milhões de $\mathrm{m}^{3}$. De acordo com a ABPM (1989b) esses dados estão sujeitos a uma variação de $20 \%$. Confrontando estes dados, com aqueles apresentados 
na Tabela 5, verifica-se uma disparidade em relação ao número de serrarias e à capacidade instalada.

Nos estados do Pará e Rondônia concentram-se as serrarias da Amazônia, cerca de $67 \%$ do total, que respondem por $91 \%$ da produção de madeira serrada da região (TEREZO, 1990).

As serrarias amazônicas são tipicamente unidades pequenas com produção anual inferior a $5000 \mathrm{~m}^{3}$. As serrarias de porte médio a grande, com produção anual acima de $5000 \mathrm{~m}^{3}$, embora representem apenas $28 \%$ do total de serrarias, são responsáveis por $70 \%$ da produção amazônica (SBS, s.d.).

A grande quantidade de pequenas serrarias existentes nessa região se deve às facilidades de instalação em função do reduzido investimento inicial, da falta de diferenciação do produto, do reduzido nível tecnológico e da grande disponibilidade de matéria-prima (SBS, s.d.).

A produção de madeira serrada é consumida em sua maior parte, $77 \%$ do total, nos grandes centros urbanos localizados nas regiões Sudeste e Sul do País (ABPM, 1989b).

$\mathrm{Na}$ Tabela 6 (página 23), apresenta-se a distribuição da produção anual de madeira serrada pelos diversos segmentos demandantes, no ano de 1989 (ABPM, 1989b). Nessa Tabela, observa-se que 55\% da produção de madeira serrada foi destinada aos segmentos revenda e engenharia (construção civil). Como as revendas atendem às marcenarias e também à construção civil, pode-se inferir que a construção civil é o segmento ao qual se destina a maior parte da madeira produzida no Brasil.

Com relação à avaliação industrial do setor, os indicadores são negativos. O nível de produtividade, a qualidade dos produtos e o grau de atualização são baixos (ABPM, 1989b).

A avaliação tecnológica do setor também é deficiente. Segundo informações da ABPM (1989b) os investimentos em P\&D são 
reduzidos, há um número pequeno de pesquisadores concentrados em entidades estatais, sendo que a informação tecnológica gerada não é adequadamente divulgada e utilizada. Embora o País disponha de normas técnicas para classificação de madeira serrada, estas não são empregadas e a preocupação com a qualidade ainda é incipiente.

Tabela 6 - Distribuição aparente da produção brasileira de madeira serrada em 1989.

\begin{tabular}{lcc}
\hline Segmento & \multicolumn{2}{c}{ Volume de madeira serrada } \\
$\left(\mathrm{Mm}^{3}\right)$ & $(\%)$ \\
\hline Indústrias em geral & 2,25 & 15 \\
Indústrias de móveis & 2,25 & 15 \\
Engenharia (construção civil) & 3,00 & 20 \\
Revenda & 5,25 & 35 \\
Embalagem & 1,80 & 12 \\
Exportação & 0,45 & 3 \\
TOTAL & 15,0 & 100 \\
& & \\
\hline Fonte: ABPM (1989b) & &
\end{tabular}

Fonte: ABPM (1989b)

Numa pesquisa conduzida junto aos segmentos de revenda e de engenharia localizados nas regiões Sul e Sudeste, que são os principais demandantes de madeira, a ABPM (1989a) detectou diversos problemas relacionados ao comércio de produtos de madeira.

Junto ao setor de revenda, a ABPM (1989a) relata os seguintes principais problemas, com seus respectivos valores relativos: 
- alto custo do frete rodoviário, $23,4 \%$;

- inconstância de preços das mercadorias, com distorções bastante acentuadas, $17,0 \%$;

- falta de regularidade nas entregas, principalmente por parte dos produtores da Amazônia, 10,6\%;

- falta de fornecedores idôneos, 9,6\%;

- falta de qualidade, tanto da madeira fornecida pela Amazônia (serragem e acondicionamento ruins), como da Região Sul (péssimo desempenho do pinus), $8,6 \%$.

No segmento engenharia (construção civil), a ABPM (1989a), assinala os seguintes principais problemas:

- falta de padronização, quanto a qualidade, bitolas, comprimentos etc., $23,5 \%$;

- irregularidade nas entregas, afetando o cronograma das obras, $17,6 \%$;

- alto custo e irregularidade do transporte rodoviário, além dos problemas de descarga, $13,7 \%$;

- preços altos e inconstantes, com prazos apertados para pagamento, 13,7\%;

- falta de fornecedores idôneos, $9,8 \%$.

As deficiências da indústria de madeira serrada no Brasil, descritas acima, são semelhantes àquelas existentes em outros países em desenvolvimento.

A UNIDO (1983) afirma que, devido às baixas exigências dos mercados locais, as serrarias dos paises em desenvolvimento são pequenas $e$ ineficientes. Utilizam um pequeno número de espécies, o equipamento é inadequado, com o conseqüente baixo rendimento de $35 \%$, e 
faltam serviços de secagem e de assistência tecnológica para resolver os problemas de produção. Como resultado, segundo a UNIDO (1983), o produto resultante é caro e de baixa qualidade.

Ao lado desses problemas tecnológicos e comerciais o setor tenderá a enfrentar problemas com a matéria-prima.

As crescentes pressões ambientais para a adoção do plano de manejo sustentado na Floresta Amazônica, poderão, de um lado, resolver os problemas de abastecimento através da perenização da produção florestal de áreas próximas às indústrias e diminuir o impacto sobre o valor ecológico das mesmas (SBS, s.d.).

No entanto, por outro lado, a adoção dessa prática acarretará um aumento nos custos de obtenção da matéria-prima da ordem de 56\% (GAMA e SILVA \& BRAZ, 1993) e, mantidas as atuais regras de reposição florestal, através da aquisição de cotas de reflorestamento, o manejo florestal será inviável economicamente (BARRETO et alii, 1993).

Nas regiōes Sudeste e Sul, os reflorestamentos existentes deverão preencher parcialmente o déficit de suas florestas nativas, somente no curto e médio prazos (SBS, s.d.). Essa perspectiva está baseada na baixa reposição florestal, na extinção dos incentivos fiscais para reflorestamento e na recessão econômica que atinge o País desde a década passada, criando uma falsa idéia de abundância de matéria-prima (SBS, s.d.).

As informações mais recentes sobre a área reflorestada do Estado de São Paulo (KRONKA et alii, 1993) assinalam a existência de 523.166 ha de eucalipto e de 206.903 ha de pinus, representando, respectivamente, 2,11 e 0,84\% da área territorial do Estado.

SUCHEK (1988) estima que, mantidas as áreas de pinus existentes em 1988 e sendo estas submetidas a uma rotação de 20 anos, com $52 \%$ da produção destinada para processamento mecânico, em meados da 
próxima década ocorrerá a extinção dessas áreas e forte déficit de matériaprima florestal.

A despeito dos fatores restritivos mencionados anteriormente, o Brasil dispõe de: uma das maiores reservas de florestas tropicais do mundo; terras, clima e tecnologia para implantação de reflorestamentos e mercados potenciais, interno e externo, para a madeira serrada (ABPM, 1989b e SBS, 1990).

Algumas diretrizes para o setor de produção de madeira serrada são apresentadas a seguir (ABPM, 1989b; SBS, s.d.; SBS, 1990 e TEREZO, 1990):

- criar mecanismos para a retomada dos reflorestamentos industriais e de proteção;

- facilitar a importação de equipamentos modernos;

- motivar um maior aporte de investimentos estatais e privados no desenvolvimento tecnológico da produção da matériaprima e no seu processamento;

- intensificar a atuação dos profissionais da área, visando consolidar as diretrizes propostas para a melhoria do desempenho do setor.

\subsection{Espécies de madeira utilizadas}

O padrão de utilização das espécies de madeiras, ao longo deste século, segue o desenvolvimento da indústria brasileira de madeira serrada.

No início deste século, com o crescimento acelerado das cidades do Rio de Janeiro e São Paulo, as madeiras importadas do hemisfério norte eram as responsáveis pelo atendimento da demanda da construção civil. 
BELLO \& SILVA (1908) apontam o uso do pinheiroamericano e ANDRADE (1923) menciona o uso do pinho-de-riga e do choupoda-rússia. CHIMELO (1994) ${ }^{5}$, relata ser relativamente comum a identificação da madeira de pinho-de-riga (Pinus sylvestris L.) proveniente de demolições de casas antigas na Cidade de São Paulo.

A expansão das serrarias no Sul do País, aliada às medidas protecionistas do governo brasileiro, fizeram com que o pinho-doparaná conquistasse definitivamente o mercado interno, a partir das décadas de 10 e 20 (BELLO \& SILVA, 1908; ANDRADE, 1923 e AZEREDO, 1987).

Além do pinho-do-paraná, outras madeiras disponiveis nas regiōes Sudeste e Sul passaram a ser empregadas na construção civil, destacando-se a peroba-rosa, o cedro (Cedrela spp) e as canelas (Ocotea spp e Nectandra spp), segundo CHIMELO (1988).

Esse conjunto de madeiras predominou até o final da década de 70 e início da de 80 . Segundo SOARES $(1981)^{7}$, citado por CHIMELO $(1988)^{8}$, o construtor dificilmente utilizava outras espécies numa obra, desde a armação de fôrmas até o uso de lâminas decorativas.

Em 1971, em trabalho conduzido na Grande São Paulo, PRIMO \& NAHUZ (1971) ${ }^{9}$, mencionam o predomínio, em termos volumétricos, do pinho-do-paraná e da peroba-rosa sobre outras madeiras.

${ }^{5}$ CHIMELO, J.P. (IPT. Laboratório de Anatomia e Identificação de Madeiras) Comunicação pessoal, 1994.

${ }^{6}$ CHIMELO, J.P. Controle de qualidade de madeiras da Região Amazônica. Trabalho apresentado no Workshop Internacional sobre Anatomia de Madeiras dos Países Membros do Tratado de Cooperação Amazônica, realizado durante o XXXIX Congresso Nacional de Botânica, Belém, 1988.

${ }^{7}$ SOARES, L. Madeira - setor já pode identificar os tipos, conforme o uso. $A$ Construção, Rio de Janeiro, (184): 38-9, 1981.

${ }^{8}$ CHIMELO, J.P.(1988) op. cit.

${ }^{9}$ PRIMO, B.L. \& NAHUZ, M.A R. (IPT, Divisão de Madeiras) Levantamento de dados em indústrias que utilizam madeira e seus derivados. 1971. 
Esses autores reuniram as diversas madeiras encontradas no levantamento, em grupos de aplicações. $\mathrm{Na}$ Tabela 7 , são apresentados os grupos de madeiras ligados à construção civil.

Tabela 7 - Agrupamento das espécies de madeira por aplicações na construção civil (base ano de 1971)

Tacos

Esquadrias

Carpintaria peroba-rosa, ipê, amendoim, paumarfim, cabriúva, faveiro e jatobá. peroba-rosa, canela, louro, cedro, bicuíba-rosa, pinho, ipê, cabriúva, freijó, perobinha e jequitibá. peroba-rosa, cedro, ipê, jatobá, cabriúva e imbuia.

Fonte: PRIMO \& NAHUZ (1971)

NAHUZ (1975) aponta o pinho-do-paraná como a madeira mais consumida na Grande São Paulo, no ano de 1974, representando 85,8\% do total. O restante foi composto por uma mistura de 53 espécies; porém, concentrando-se nas espécies tradicionais (em ordem decrescente de utilização): peroba-rosa, cedro, canela, imbuia e ipê, procedentes, em mais de $85 \%$ do volume, de estados das regiões Sul, Sudeste e Centro - Oeste. Segundo este autor as madeiras amazônicas tinham uma participação volumétrica muito pequena.

Para a mesma época, RIVOLI et alii (1978), ao elaborarem um diagnóstico do uso da madeira na construção habitacional, 
detectaram diversas madeiras sendo usadas em seis capitais brasileiras. Aquelas encontradas em São Paulo, para os usos apontados, são apresentadas na Tabela 8.

Tabela 8 - Espécies de madeiras utilizadas na construção civil habitacional, na Cidade de São Paulo (base anos 1974-75).

Forma de concreto

Tapume, barracos e andaime

Estrutura de cobertura

Forro

Porta de apartamento

Porta de edifício

Caixilho de janela

Lambril e painel decorativo

Piso

Outros pinho-do-paraná, peroba-rosa e virola.

pinho-do-paraná e peroba-rosa.

peroba-rosa, pinho-do-paraná e eucalipto.

pinho-do-paraná.

cedro, imbuia, cerejeira, sucupira, caviúna, peroba-rosa, canela e pinhodo-paraná.

cedro, jequitibá e peroba-rosa.

peroba-rosa, cedro e canela.

cerejeira, peroba-rosa, louro, jacarandá, imbuia e caviúna.

peroba-rosa, ipê, imbuia e sucupira. imbuia, canela e pinho-do-paraná

Fonte: RIVOLI et alii (1978)

As madeiras listadas nessa Tabela, excetuando-se as usadas em lambris, painéis decorativos e portas de apartamentos, são 
basicamente aquelas apontadas por NAHUZ (1975). No entanto, digno de nota é a presença do eucalipto sendo usado em estrutura de cobertura.

Cuidado deve ser tomado ao se analisar informações sobre espécies de madeira sendo comercializadas e/ou utilizadas, em razão dos freqüentes enganos quanto à identificação das mesmas (IBDF, 1985).

Em meados da década passada, o IBDF, em associação com o Instituto de Pesquisas Tecnológicas do Estado de São Paulo - IPT e o Instituto Nacional de Pesquisas da Amazônia - INPA, elaborou um projeto a nível nacional que, dentre os seus múltiplos objetivos, buscou coletar e identificar pela anatomia do lenho as madeiras amazônicas que estavam sendo processadas mecanicamente e/ou consumidas nos mercados nacional e internacional (IBDF, 1985).

Para tanto, foram visitados 323 produtores (serrarias, laminadoras e fábricas de compensado) localizados nos estados da Amazônia, exceto Acre e Amapá. Também foram visitados 491 consumidores (fábricas de móveis, empresas de construção civil, comércio de madeiras etc.) distribuídos por diversos estados de todas as regiōes do País (IBDF, 1985)

Em cada produtor ou consumidor visitados foram coletadas amostras das madeiras amazônicas que estavam sendo processadas ou utilizadas. Cada amostra de madeira coletada foi segmentada e distribuída para os laboratórios de identificação de madeiras das entidades participantes (IBDF, 1985).

As análises realizadas revelaram a existência de 250 espécies de madeiras amazônicas sendo produzidas ou comercializadas, no ano de 1984, no Brasil (IBDF, 1985). Essa diversidade é reflexo da composição florística das florestas tropicais, cuja heterogeneidade é freqüentemente responsabilizada, como a maior dificuldade a ser suplantada para uma exploração mais econômica da floresta (ANDRADE, 1923; NAHUZ, 1974; UNIDO, 1983 e TEREZO, 1990). 
No entanto, uma análise das espécies identificadas, em associação com o volume de produção revelou que, 14 tipos de madeiras (reunião de espécies difíceis de serem separadas comercialmente), eram responsáveis por $75,6 \%$ do volume da madeira produzida na população amostrada (IBDF, 1985), conforme pode ser visto na Tabela 9.

Tabela 9 - Madeiras amazônicas hierarquizadas por produção, nos estados do Amazonas, Maranhão, Mato Grosso, Rondônia e Roraima (base: ano de 1984).

\begin{tabular}{llc}
\hline \multicolumn{2}{c}{ Madeira } & $\begin{array}{c}\text { \% da Produção } \\
\text { Amostrada }\end{array}$ \\
\hline mogno popular & Nome científico & 15,7 \\
ucuúba & Swietenia macrophylla & 8,7 \\
cerejeira & Virola spp & 7,7 \\
breu-sucuruba & Amburana cearensis & 7,4 \\
ipê & Trattinickia spp & 6,3 \\
jatobá & Hymenaea spp & 5,6 \\
muiratinga & Maquira sclerophylla & 4,3 \\
quarubarana & Erisma uncinatum & 3,8 \\
jacareúba & Calophyllum brasiliense & 3,2 \\
angelins & Andira spp, Hymenolobium spp, Vatairea & \\
& paraensis e Vataireopsis speciosa & 3,1 \\
faveiras & Parkia spp & 2,7 \\
muiracatiara & Astronium spp & 2,5 \\
cupiúba & Goupia glabra & 2,4 \\
sumaúma & Ceiba pentandra & 2,2 \\
& SUB-TOTAL & 75,6 \\
\hline
\end{tabular}

Fonte: IBDF (1985) 
O estudo também revela que, a maior diversidade de espécies que estavam sendo utilizadas, ocorria nas próprias regiōes de produção. Já nas regiōes Sudeste e Sul foi encontrada a menor variedade de madeiras (IBDF, 1985).

Quanto aos nomes populares das madeiras, foi constatada uma profusão deles, em muitos casos inadequados ou incorretos e, em outros, foram nomes criados para facilitar a comercialização de uma determinada madeira (IBDF, 1985)

Segundo o IBDF (1985), o maior obstáculo para uma utilização mais intensa das madeiras amazônicas, está relacionada ao desconhecimento das mesmas junto aos mercados nacional e internacional .

Outra conclusão importante do estudo é que foi constatado o uso inadequado de várias madeiras, o que poderá afetar o desempenho comercial das mesmas no mercado doméstico (IBDF, 1985).

Segundo CHIMELO $(1988)^{10}$, após a realização de diversas inspeções em madeiras serradas utilizadas em estrutura de cobertura de casas de conjuntos populares localizados no Estado de São Paulo, foi constatada a substituição de madeiras tradicionais como peroba-rosa, canelas, cedro e pau-marfim, por outras provenientes, principalmente, da Região Amazônica.

Esse autor constatou também que a maior parte das peças rejeitadas tiveram como problema a presença do alburno (52\%) e, em seguida, o emprego de espécies de madeiras não indicadas para o uso em estrutura de cobertura (34\%).

$\mathrm{Na}$ Tabela 10 apresenta-se a relação das principais espécies identificadas, hierarquizadas através do percentual relativo ao número total de peças aprovadas.

${ }^{10}$ CHIMELO (1988) op. cit. 
Nessa Tabela observa-se a presença da peroba-rosa; porém, com uma participação relativa bem inferior à da guarucaia e do jatobá. As madeiras amazônicas (assinaladas com *) representam $35 \%$ do total de peças aprovadas. Não foi constatada a presença do pinho-do-paraná.

Tabela 10 - Principais espécies de madeiras empregadas em estrutura de cobertura de casas de conjuntos populares localizados no estado de São Paulo (base: ano de 1987).

\begin{tabular}{lcc}
\hline & Madeira & \% do Total de \\
Nome popular & Nome científico & Peças Aprovadas \\
\hline
\end{tabular}

$\begin{array}{llr}\text { guarucaia } & \text { Peltophorum vogelianum } & 39 \\ \text { jatobá * } & \text { Hymenaea spp } & 20 \\ \text { angico-vermelho } & \text { Parapiptadenia rigida } & 9 \\ \text { peroba-rosa } & \text { Aspidosperma polyneuron } & 7 \\ \text { muiracatiara * } & \text { Astronium lecointei } & 7 \\ \text { tatajuba * } & \text { Bagassa guianensis } & 4 \\ \text { angico-preto } & \text { Anadenanthera macrocarpa } & 4 \\ \text { angelim-pedra * } & \text { Hymenolobium petraeum } & 2 \\ \text { taiúva } & \text { Chlorophora tinctoria } & 2 \\ \text { cupiúba * } & \text { Goupia glabra } & 1 \\ \text { guaritá } & \text { Astronium graveolens } & 1 \\ \text { maçaranduba } & \text { Manilkara sp } & 1 \\ \text { outras 21 espécies } & \end{array}$

Fonte: CHIMELO (1988)

* espécies provenientes da Amazônia

${ }^{11}$ CHIMELO (1988) op. cit. 
$\mathrm{Na}$ Tabela 11 são apresentadas as informações coletadas pela ABPM (1989a) sobre as espécies de madeiras que estavam sendo usadas sob diversas formas (madeira serrada, laminada, compensado etc.), nos setores de revenda e engenharia, nas regiões Sul e Sudeste, no ano de 1988.

Tabela 11 - Espécies de madeiras empregadas, sob diversas formas, nos setores de revenda e construção civil, nas regiōes Sul e Sudeste (base: ano de 1988).

\begin{tabular}{|c|c|c|}
\hline \multirow[t]{2}{*}{ Madeira } & \multicolumn{2}{|c|}{ Participação ( \% ) } \\
\hline & Revenda & Construção Civil \\
\hline pinho-do-paraná & 25,1 & 13,7 \\
\hline pinus & 8,8 & 5,0 \\
\hline canela & 7,3 & 6,9 \\
\hline imbuia & 6,7 & 2,0 \\
\hline peroba-rosa & 7,2 & 4,6 \\
\hline cedro & 4,8 & 3,3 \\
\hline cerejeira & 4,7 & 1,2 \\
\hline mogno & 8,4 & 3,4 \\
\hline cambará & 9,0 & 11,2 \\
\hline virola & 4,6 & 4,7 \\
\hline jatobá & 3,2 & 4,0 \\
\hline outras ${ }^{1}$ & 10,2 & --- \\
\hline outras $^{2}$ & --. & 40,0 \\
\hline
\end{tabular}

Fonte: ABPM (1989a)

${ }^{1}$ outras: itaúba, andiroba, açacu, cumaru, angelim, sucupira, ipê etc.

${ }^{2}$ outras: andiroba, maçaranduba, açacu, itaúba, cumaru, angico, canafístula, ipê etc. 
Observa-se, na Tabela 11, que no setor de revendas as madeiras tradicionais (pinho-do-paraná, canela, imbuia, peroba-rosa e cedro) eram ainda as mais comercializadas. Dentro deste grupo, o destaque era para o pinho-do-paraná com participação relativa de $25,1 \%$.

Já no setor de engenharia as madeiras tradicionais tinham uma participação menor; porém, ainda significativa, com o pinho-do-paraná destacando-se como a mais utilizada, seguida de perto por uma madeira amazônica, o cambará. O grupo "outras", composto quase que exclusivamente por madeiras amazônicas, representava $40,0 \%$ da madeira empregada pelo setor, refletindo a tendência de utilização de uma mistura de espécies de madeiras amazônicas.

Na Tabela 11, nota-se também que o pinus era a única madeira de reflorestamento citada nas estatísticas para ambos setores.

A ABPM (1989a) menciona que o setor de revendas se abastecia com produtos de madeira fornecidos principalmente pela Região Sul (52,0\% do total) e pelas regiões Norte e Centro - Oeste $(29,8 \%$ e $16,3 \%$, respectivamente). No setor de engenharia, a Região Norte destacava-se como maior fornecedora (52,9\% do total), seguida pelas regiōes Sul e Centro - Oeste $(29,4 \%$ e $16,2 \%)$, respectivamente.

$\mathrm{Na}$ Tabela 12 são apresentados os resultados obtidos pelo IPT (1993) ao identificar as madeiras serradas utilizadas em estrutura de cobertura de casas de dois conjuntos habitacionais populares localizados no interior do Estado de São Paulo.

A tendência de uso de uma mistura de espécies de madeiras amazônicas fica evidente ao se analisar os resultados apresentados na Tabela 12, onde se nota a identificação de 36 espécies de madeiras dessa região. 
Tabela 12 - Espécies de madeiras identificadas em estrutura de cobertura de casas em dois conjuntos populares localizados no interior do Estado de São Paulo (base: ano de 1993).

\begin{tabular}{ll}
\hline Nome Popular & Nome Científico \\
\hline abiurana & Pouteria sp \\
angelim & Andira sp \\
angelim-pedra & Hymenolobium sp \\
angelim-vermelho & Dinizia excelsa \\
araracanga & Aspidosperma sp \\
castanheira & Bertholletia excelsa \\
cedrinho & Erisma uncinatum \\
cedrorana & Cedrelinga catenaeformis \\
copaiba & Copaifera sp \\
cumaru & Dipteryx odorata \\
cupiúba & Goupia glabra \\
fava-orelha-de-macaco & Enterolobium schomburgkii \\
faveira-alérgica & Dimorphandra sp \\
garapa & Apuleia leiocarpa \\
glícia & Glicydendron amazonicum \\
goiabão & Planchonella pachycarpa \\
guariúba & Clarisia sp \\
ipê & Tabebuia sp \\
itaúba & Mezilaurus itauba \\
jacareúba & Calophyllum brasiliense \\
jarana & Holopyxidium jarana \\
louro ou canela & Nectandra sp ou Ocotea sp \\
maçaranduba & Manilkara sp \\
mandioqueira & Qualea sp \\
muiracatiara & Astronium sp \\
pau-amarelo & Euxylophora paraensis \\
pau-jacaré & Laetia procera \\
pau-roxo & Peltogyne sp \\
peroba & Aspidosperma sp \\
pequiá & Caryocar sp \\
quaruba & Vochysia sp \\
rosadinho & Micropholis sp \\
tanibuca & Terminalia sp \\
taxi & Tachigalia sp \\
timborana & Piptadenia sp \\
uxi & Endopleura sp \\
\hline Fonte: IPT (1993) &
\end{tabular}

Fonte: IPT (1993) 
OZÓRIO FILHO \& ALFONSO (1995) ${ }^{12}$ ao procederem a identificação anatômica de 120 amostras de madeiras coletadas em 12 distribuidoras localizadas nos bairros de Pinheiros e Brás, na cidade de São Paulo, distinguiram 19 espécies, sendo 16 de origem nativa (amazônicas e não amazônicas) e três de reflorestamento: pinus, teca e eucalipto. Esses resultados são apresentados na Tabela 13.

Tabela 13 - Espécies de madeiras identificadas em coleta realizada em dois bairros (Pinheiros e Brás) na Cidade de São Paulo (base: ano de 1994).

\begin{tabular}{ll}
\hline Nome Popular & Nome Científico \\
\hline amendoim & Pterogyne nitens \\
andiroba & Carapa guianensis \\
angelim-pedra & Hymenolobium petraeum \\
angico & Parapiptadenia sp \\
cabriúva & Myroxylon sp \\
canela ou louro & Ocotea sp ou Nectandra sp \\
cedro & Cedrela sp \\
cedrorana & Cedrelinga catenaeformis \\
cerejeira & Torresea cearensis \\
cumaru & Dipteryx sp \\
eucalipto & Eucalyptus sp \\
freijó & Cordia goeldiana \\
garapa & Apuleia leiocarpa \\
guarucaia & Peltophorum vogelianum \\
imbuia & Ocotea porosa \\
ipê & Tabebuia sp \\
jatobá & Hymenaea sp \\
louro-preto & Cordia trichotoma \\
marupá & Simarouba sp \\
mogno & Swietenia macrophylla \\
\hline
\end{tabular}

${ }^{12}$ OZÓRIO FILHO, H.L. \& ALFONSO, V.A . Identificação anatômica das madeiras utilizadas na Cidade de São Paulo (Relatório Parcial). Instituto de Biociências - USP. 1995. 
Tabela 13 - Espécies de madeiras identificadas em coleta realizada em dois bairros (Pinheiros e Brás) na Cidade de São Paulo (base: ano de 1994) (continuação).

\begin{tabular}{ll}
\hline Nome Popular & Nome Científico \\
\hline muiracatiara & Astronium sp \\
pau-marfim & Balfourodendron riedelianum \\
pequiá & Caryocar sp \\
peroba-mico & Aspidosperma sp \\
peroba-rosa & Aspidosperma polyneuron \\
pinho-do-paraná & Araucaria angustifolia \\
pinus & Pinus sp \\
quarubarana & Erisma uncinatum \\
sucupira & Bowdichia nitida \\
tamboril & Enterolobium contortisiliquum \\
tatajuba & Bagassa guianensis \\
teca & Tectona grandis \\
& \\
\hline
\end{tabular}

Fonte: OZÓRIO FILHO \& ALFONSO (1995) ${ }^{13}$

MONTEIRO et alii, 1995 e CORDEIRO et alii, 1995, em pesquisa conduzida junto ao comércio da cidade de Piracicaba, no interior de São Paulo, identificaram madeiras predominantemente de origem nativa cedrinho (Erisma uncinatum), ipê (Tabebuia serratifolia), mogno (Swietenia macrophylla), jatobá (Hymenaea courbari) e imbuia (Ocotea porosa) - sendo utilizadas nos setores de mobiliário, esquadrias e estruturas. Espécies de pinus e de eucalipto, embora com ocorrência relativa menos importante, também foram identificadas.

${ }^{13}$ OZÓRIO FILHO \& ALFONSO (1995) op. cit. 
Mesmo encontrando espécies provenientes de reflorestamento no mercado de madeira serrada na Cidade de São Paulo, a substituição em larga escala das madeiras provenientes de florestas nativas, por essas espécies, ainda enfrenta problemas tecnológicos e de aceitação por parte do mercado consumidor. Mesmo que tais problemas sejam suplantados, há a necessidade de investimentos para implantação de florestas homogêneas para atender o mercado de madeira serrada da região Sudeste do País (IBAMA \& FUNATURA, 1995).

\subsection{A identificação de madeiras}

Desde o princípio de sua história, o homem busca ordenar os diversos organismos vivos no sentido de formar grupos com finalidade prática e econômica. Assim, estabeleceu-se um conhecimento sobre grupos de vegetais que poderiam servir como alimento, medicamentos, material para construção de habitações, obtenção de energia etc. (HEYWOOD, 1970).

Do ponto de vista biológico a classificação é essencial. Os diversos cientistas que trabalham com plantas necessitam de um sistema de referência paras as mesmas, pois ligado a um nome existe uma série de individuos com características em comum (HEYWOOD, 1970).

Quando um botânico, um ecólogo ou um engenheiro florestal identifica uma árvore como sendo, por exemplo, Swietenia macrophylla King., o significado básico dessa identificação é de que, salvo erros e pequenas variações, esta árvore a exemplo de outras árvores referidas como Swietenia macrophylla, em qualquer parte do mundo onde possam estar crescendo, sejam essencialmente semelhantes entre si, tanto em aspectos morfológicos, como fisiológicos, bioquímicos etc. (HEYWOOD, 1970).

Essa característica da classificação biológica pode ser denominada "predizibilidade". Seu significado implica que um grupo de plantas 
reunidas numa categoria, por possuírem características comuns, quando uma determinada característica, não utilizada para criar essa categoria, for encontrada para um certo membro do grupo, haverá uma grande possibilidade que os outros membros do grupo a possuam (HEYWOOD, 1970).

Freqüentemente ocorrem confusões com os termos sistemática e taxionomia. Segundo HEYWOOD (1970), sistemática "é o termo usado para designar o estudo científico da diversidade e diferenciação dos organismos e as relações que existem entre eles". Taxionomia "é a parte da sistemática que trata do estudo da classificação, incluindo suas bases, principios, procedimentos e regras". Ainda, segundo o mesmo autor, classificação "é o processo de ordenar as plantas em grupos dispostos hierarquicamente; o termo é também usado para expressar o arranjo resultante desta atividade".

Neste contexto, a identificação é o processo de alocar um certo vegetal numa determinada categoria taxionômica ou táxon (espécie, gênero etc.).

A classificação de uma vegetal arbóreo, matéria-prima para a produção de madeira serrada, é realizada considerando principalmente os seus órgãos reprodutores (flores e frutos), como também outras características morfológicas da árvore (casca, folhas etc.).

A identificação de uma árvore depende, portanto, da disponibilidade dessas características morfológicas. Ocorre que a presença dos órgãos reprodutores da árvore é efêmera, o que dificulta, por exemplo, a sua identificação nos trabalhos de inventário florestal (FEDALTO et alii, 1989).

No processo de extração e de transformação da árvore em madeira serrada, obviamente, as características morfológicas do vegetal, necessárias para a identificação, são eliminadas. 
Nesse contexto, o estudo anatômico comparativo do lenho tem demonstrado sua utilidade na correta identificação das espécies de madeiras (PEREIRA, 1933; MAINIERI et alii, 1983).

Segundo KEENAN \& TEJADA (1984), a utilização adequada das espécies de madeira depende de procedimentos que garantam a identificação das mesmas, quer seja como árvores, toras ou madeira serrada.

CHIMELO \& ALFONSO (1985) apontam a identificação como a base dos estudos de caracterização da madeira e sua utilidade no comércio, onde propicia meios para se detectar enganos e fraudes.

Mesmo no campo da sistemática, a anatomia de madeiras tem contribuído de maneira significativa, como no caso da posição sistemática de famílias primitivas de angiospermas (Winteraceae, Trochodendraceae etc.) e no estabelecimento de linhas de especialização evolutivas do lenho (HEYWOOD, 1970).

Nos estudos anatômicos de identificação de madeiras são utilizadas duas abordagens distintas, a macroscópica e a microscópica (PEREIRA, 1933; PANSHIN \& DE ZEEUW, 1970; CHIMELO \& ALFONSO, 1985).

$\mathrm{Na}$ identificação macroscópica são observadas caracteristicas que requerem pouco ou nenhum aumento. Tais características são reunidas em dois grupos: as organolépticas e as anatômicas.

As características organolépticas englobam: cor, brilho, odor, gosto, grã, textura, densidade, dureza e desenhos. Por serem variáveis e também devido à semelhança das mesmas em diferentes madeiras, estas características, em muitos casos, não levam à identificação correta da madeira, não devendo serem utilizadas separadas das anatômicas. Exemplo disso, é a análise dos resultados de identificação de madeiras amazônicas realizada pelo IBDF (1985), onde se verificou, que muitas madeiras foram identificadas erroneamente, por produtores ou consumidores, pelo fato delas apresentarem 
cor e densidade de massa (termo de acordo com a ASSOCIAÇĀO BRASILEIRA DE NORMAS TÉCNICAS - ABNT, 1992) semelhantes.

As características anatômicas, como camadas de crescimento, tipos de parênquima, poros (vasos) e raios; são observadas à vista desarmada ou com auxílio de uma lupa de 10 vezes de aumento. Em conjunto com as observações das características organolépticas, este tipo de análise permite identificar muitas das espécies comercializadas no País.

$\mathrm{Na}$ identificação microscópica são observadas as características dos tecidos (muito freqüentemente já definidas no exame macroscópico) e das células constituintes do lenho, que não são distintas sem o uso de microscópio, tais como: tipos de pontoações, ornamentações da parede celular, composição celular dos raios, dimensões celulares, presença de cristais etc.

O uso de um processo ou outro, ou o uso simultâneo, depende da habilidade e treinamento do observador (CORE et alii, 1976).

Porém, para ambos tipos de identificação, é de fundamental importância que o observador disponha de uma coleção de madeiras, cujos exemplares sejam rastreáveis a amostras-padrão disponiveis em laboratórios especializados. Nestes, na medida do possivel, as amostras devem provir de árvores identificadas botanicamente (com rastreabilidade) ou, ao menos, que tenham sido identificadas anatomicamente por uma laboratório idôneo (ZENID, 1992) ${ }^{14}$.

A multiplicidade de espécies existentes faz da identificação anatômica de madeiras uma tarefa relativamente complicada (CORE et alii, 1976).

${ }^{14}$ ZENID G.J. (Seminário apresentado na disciplina 782 - Identificação de madeiras, do Curso de pós-graduação em Ciência e Tecnologia de Madeiras, ESALQ/USP) A contribuição da identificação anatômica para o comércio de madeiras no Brasil. 1992. 
$\mathrm{Na}$ tentativa de diminuir as dificuldades, os anatomistas De madeira procuraram desenvolver métodos auxiliares como: a publicação de manuais ilustrados, as chaves dicotômicas, os cartōes-perfurados e os bancos de dados eletrônicos (ALFONSO, 1987; CHIMELO et alii, 1993).

Além da anatomia da madeira tradicional, segundo ALFONSO (1987), vários pesquisadores aplicaram outras metodologias, como: a análise de componentes principais, estereologia e a anatomia da casca. PANSHIN \& DE ZEEUW (1970), mencionam também o uso de técnicas químicas para identificação de madeiras.

Uma prática que deve ser combatida, é aquela de se buscar na literatura especializada o nome científico correspondente a um determinado nome popular de madeira. Ocorre, como foi mostrado e analisado extensivamente pelo IBDF (1985), que a nomenclatura popular das madeiras é extremamente rica e variável, o que propicia o surgimento de erros grosseiros de identificação.

\subsection{Grupamento de madeiras por uso final}

A pesquisa de produtos florestais, em especial nos países tropicais e subtropicais, tem se concentrado no potencial de utilização de uma mistura de espécies de madeiras pouco conhecidas (lesser known species) extraídas de florestas nativas e naquelas espécies geradas em reflorestamentos (KEATING, 1983 e HENG, 1988).

HANSOM (1983) menciona que nas florestas tropicais há, em média, $157 \mathrm{~m}^{3} /$ ha de madeiras com dimensões comerciais e que, no entanto, somente $8,4 \mathrm{~m}^{3} / \mathrm{ha}$, ou seja, $5,25 \%$ do total é aproveitado. Isto, segundo este autor, acarreta um incremento significativo nos custos de extração por unidade de área, o que pode tornar a madeira menos competitiva frente a outros materiais. Como conseqüência, o benefício obtido pelos países 
produtores é bem inferior ao esperado e as reservas tenderão a ser rapidamente devastadas.

NAHUZ (1974) analisando um inventário florestal executado numa área de $3190 \mathrm{~km}^{2}$ na bacia do rio Paracuru, Estado do Pará, aponta a existência de um volume médio de $175 \mathrm{~m}^{3} / \mathrm{ha}$, composto por 61 espécies ou grupos de espécies (espécies pertencentes, em geral, ao mesmo gênero, cuja distinção é difícil na prática), sendo que mais de $90 \%$ das mesmas eram pouco conhecidas comercialmente.

Ao analisar a densidade de massa, a $15 \%$ de teor de umidade, das madeiras existentes nessa região, NAHUZ (1974) encontrou valores variando entre $0,33 \mathrm{~g} / \mathrm{cm}^{3}$ para o parapará (Jacaranda copaia) e 1,04 $\mathrm{g} / \mathrm{cm}^{3}$ para a maçaranduba (Manilkara huberi), com uma média ponderada de $0,62 \mathrm{~g} / \mathrm{cm}^{3}$.

Segundo NAHUZ (1974) e KEATING (1983), a existência dessa variabilidade torna impraticável a promoção e a comercialização abrangente de todas essas espécies, sobretudo naqueles mercados abastecidos tradicionalmente por poucas espécies de madeira.

Tais circunstâncias sugerem uma abordagem para redução da heterogeneidade das madeiras, através do grupamento ou reunião das mesmas em categorias de propriedades comuns (NAHUZ, 1974; KEATING, 1983; HANSOM, 1983 e HENG, 1988).

Grupamentos ou classificação das madeiras através de suas propriedades, tais como: densidade de massa, estabilidade dimensional, resistência mecânica, durabilidade natural, cor, comportamento no tratamento preservativo, no processamento mecânico e na secagem; ou ainda, através de características, como: uso final, grupos de uso final, graus de comercialização etc., já foram elaborados por diversos autores (NAHUZ, 1974; FREITAS, 1978; WEBSTER, 1978; IBDF, 1981; SUDAM, 1981; IBDF, 1983; KEATING, 1983; MAINIERI, 1983; SODRÉ \& OLIVEIRA, 1983; KEENAN \& TEJADA, 1984; IBDF, 
1985; MELO et alii, 1986; HENG, 1988; IBDF, 1988; TEIXEIRA et alii, 1988; MAINIERI \& CHIMELO, 1989; NOGUEIRA, 1991; INPA, 1991; CHIMELO \& HUMPHREYS, 1992).

A multiplicidade de sistemas de grupamento se de um lado revela que o conceito de grupamento já é amplamente aceito, de outro lado mostra a necessidade de padronização dos procedimentos (KEATING, 1983 e HENG, 1988).

No mercado brasileiro o grupamento já é praticado, porém não tecnicamente. Estudo realizado pelo IBDF (1985), ao buscar explicações para os freqüentes enganos de identificação de madeiras amazônicas no comércio, propôs que a cor e a densidade estariam provocando esses enganos e servindo como base para grupamentos, tais como: madeiras avermelhadas e pesadas (jatobá, muiracatiara, angelim-vermelho etc.), avermelhadas e leves (mogno, cedro, quaruba, cedrinho etc.), amareladas (pau-amarelo, tatajuba, guariúba e muirajuba) e brancas (açacu, parapará, amapá etc.). Esta prática realizada sem o conhecimento do consumidor pode agravar o conceito de baixo desempenho do material.

NAHUZ (1974) menciona que a introdução de uma nova espécie em um mercado se dá, em grande parte, através da substituição de uma outra espécie de uso já consagrado. Geralmente esse processo é direcionado a um ou mais usos finais similares.

Por esta razão, ao elaborar uma estratégia de introdução de madeiras brasileiras no mercado europeu, NAHUZ (1974) propôs a classificação geral dos usos finais. Para cada uma das categorias de uso, o 
autor estabeleceu, baseado em trabalhos de ENGLERTH (1966) ${ }^{15}$ e LUTZ $(1971)^{16}$, os requisitos necessários para a classificação das madeiras.

Dessa forma, o autor grupou por usos finais as 61 madeiras detectadas no inventário florestal conduzido na região do Rio Paracuru, no Estado do Pará. NAHUZ (1974) alerta que esse tipo de grupamento é preliminar e recomenda mais pesquisa para que o uso efetivo de uma determinada madeira seja implementado.

A metodologia adotada por NAHUZ (1974), com modificaçōes relacionadas às categorias de usos e aos requisitos de classificação, foi empregada nos trabalhos relatados a seguir.

SUDAM (1981) grupou 148 madeiras do Estado do Pará, baseado em características das madeiras e em uso reportado na literatura. Neste estudo, as madeiras também foram grupadas por densidade de massa, cor, durabilidade natural e nivel de comercialização.

IBDF (1985) reuniu em grupos de usos finais 250 espécies de madeiras amazônicas, de acordo com o uso indicado na literatura e pelos produtores e consumidores entrevistados. Também foram realizados grupamentos por densidade de massa e cor.

Essa metodologia também já foi aplicada em madeiras oriundas de reflorestamentos. NOGUEIRA (1991) grupou 16 espécies de eucalipto em categorias de usos finais na construção civil, enquanto BORTOLETTO JR. (1993) ${ }^{17}$, citado por BORTOLETTO JR. \& LAHR (1993), realizava o mesmo com seis espécies e variedades de pinus.

${ }^{15}$ ENGLERTH, G.H. Framework of qualitative relantionships in wood utilization. Madison, USDA, 1966. (FPL Research paper 45).

${ }^{16}$ LUTZ, J.F. Wood and log characteristics affecting veneer production. Madison, USDA, 1971. (FPL Research paper 150).

${ }^{17}$ BORTOLETTO JR., G. Indicações para a utilização da madeira de seis espécies e variedades de pinus aplicada na construção civil. São Carlos, 1993. 119p. (Mestrado - Escola de Engenharia de São Carlos/USP). 
Para KEATING (1983) e HANSOM (1983) o grupamento de espécies apresenta maiores vantagens quando aplicado para fins estruturais do que para os de utilidade geral.

HANSOM (1983) relata que só os usos verdadeiramente decorativos não são adequados ao grupamento e que grupos de cores somente são praticáveis se o conceito é aplicado para encorajar os projetistas e especificadores a aceitar o uso de uma dentre várias espécies para um determinado uso, ao invés de misturar várias espécies para um único uso.

KEATING (1983) relata que o grupamento de madeiras baseado no conceito de adequação das mesmas para amplos grupos de usos gerais, associado com o emprego de espécie de referência, é uma forma mais eficiente de promoção comercial das chamadas espécies menos conhecidas.

Para a escolha de uma espécie de referência para cada grupo de uso final, o autor escolheu espécies bem conhecidas e que já provaram, ao longo do tempo, sua adequação ao uso final proposto.

KEATING (1983) estabeleceu um sistema de pontuação variando de um a nove, que permite comparar a espécie que se pretende utilizar com a espécie de referência. Segundo este autor, essa prática permite transmitir ao usuário, num curto espaço, um volume considerável de informações. 


\section{METODOLOGIA}

Para a consecução dos objetivos propostos para este trabalho, foi desenvolvida a metodologia relatada a seguir.

\subsection{Pesquisa junto às empresas de distribuição de madeiras e construtoras}

O trabalho foi desenvolvido na Cidade de São Paulo, SP, onde foram visitadas empresas distribuidoras de madeiras serradas, em geral lojas especializadas ou de materiais de construção, e construtoras que empregam madeira serrada em suas obras.

As empresas construtoras foram visitadas para contemplar a possibilidade de abastecimento direto de produtores (serrarias) ou de representantes destes, como também para coletar as informações sem o viés que os distribuidores pudessem gerar por razões comerciais.

A escolha das empresas distribuidoras de madeira e das construtoras foi realizada com base em anúncios de jornal, endereços disponiveis no Laboratório de Anatomia e Identificação de Madeiras - LAIM do IPT e também por visitas às empresas próximas daquelas selecionadas.

No caso das distribuidoras, foram visitadas 42 empresas localizadas nos seguintes bairros da capital: Bairro do Limão, Brás, Brooklin, Butantã, Interlagos, Ipiranga, Jardim Bonfiglioli, Jardim da Saúde, Pinheiros, Rio Bonito, Santo Amaro, Vila Gumercindo e Vila Maria. 
A relação das empresas visitadas, de acordo com o bairro em que se localizam, é apresentada no Apêndice 1 (página 144). Nessa relação, pode ser observado que houve uma intensidade amostral maior em bairros que tradicionalmente são conhecidos como centros de comercialização de madeiras, como: Bairro do Limão, Brás, Butantã e Pinheiros.

No caso das construtoras, foram visitadas 19 obras, em diferentes estágios de desenvolvimento, localizadas nos seguintes bairros da Capital: Cerqueira César, Consolação, Jardim Paulista, Paraíso, Parque Novo Mundo, Planalto Paulista, Vila Mariana, Vila Mascote e Vila Nova Conceição.

Adicionalmente, foram incluídos neste trabalho os resultados de três inspeções de recebimento, executadas por um técnico do LAIM-IPT, de lotes de madeiras serradas destinadas ao uso em estrutura de telhado de três conjuntos habitacionais populares localizados no interior de São Paulo (Araraquara, Paulínia e Salto). Este procedimento foi adotado tendo em vista a possibilidade da identificação botânica de lotes completos de madeira serrada.

A lista das construtoras cujas obras foram visitadas é apresentada no Apêndice 1 (página 144). Dentre as obras listadas, quatro são de conjuntos habitacionais populares (Projeto Cingapura, CDHU e COHAB) e as demais de edifícios residenciais não populares, com vários pavimentos.

Para efeito de um dos objetivos deste trabalho identificar as principais madeiras utilizadas/comercializadas para a construção civil habitacional - foi adotado como critério de suficiência amostral, a curva resultante da seqüência de visitas realizadas (de acordo com a data de visita) em relação ao número acumulado de espécies identificadas.

Segundo esse critério, a amostragem deve ser interrompida quando há sensivel diminuição da inclinação da curva, pois o esforço de se realizar novas amostragens não se reflete num acréscimo importante no número de novas espécies. 


\subsubsection{Coleta de informações nas empresas visitadas}

Para a coleta de informações nas empresas visitadas foram elaborados dois questionários distintos, um para os distribuidores e outro para as construtoras, conforme pode ser visto no Apêndice 2 (página 150).

Ambos os questionários foram estruturados em duas partes. A primeira foi destinada à obtenção de dados gerais sobre a empresa e sua atividade na área madeireira. A segunda parte esteve voltada para as informações específicas para cada madeira que estivesse sendo comercializada ou utilizada pela empresa.

Para as distribuidoras de madeiras serradas as informações gerais se referem a:

- razão social e endereço completo da empresa;

- nome e cargo da pessoa responsável pelas informaçōes;

- relação de espécies de madeiras comercializadas, hierarquizadas pela freqüência relativa de vendas;

- tipos de peças comercializadas de acordo com suas dimensões (vigas, tábuas, pranchas etc.) e grau de processamento (em bruto, aparelhada, emoldurada etc.);

- existência de padronização de dimensões e de qualidade das peças, e de cuidados com a madeira no que diz respeito à tratamento preservante e secagem;

- forma de aquisição da madeira (diretamente do produtor, através de representantes ou outras); e

- relação de problemas do setor.

Para as empresas construtoras as informações gerais levantadas foram basicamente as mesmas apontadas acima, exceto que se 
buscou obter informações sobre os critérios pelos quais a(s) madeira(s) é (são) escolhida (s).

Com relação às informações específicas sobre as madeiras os questionários são semelhantes, tanto para os distribuidores como para os construtores, e foram utilizados para coletar, para cada uma das espécies comercializadas ou utilizadas, as seguintes informações:

- nome popular da madeira utilizado pelo entrevistado;

- código da amostra de madeira coletada para identificação anatômica;

- campo para anotar o resultado da identificação anatômica realizada em laboratório (nomes científico e comercial);

- fontes de suprimento, usos e tipos de peças; e

- informações qualitativas sobre características de trabalhabilidade da madeira que, embora possam ser consideradas subjetivas, devem ser encaradas como uma tentativa de captar o conhecimento prático existente no setor.

Em cada entrevista realizada foi apresentada uma carta contendo explicações sobre os objetivos do trabalho e foi assegurada a confidencialidade das informações fornecidas. Após os trabalhos de laboratório, foram encaminhadas correspondências aos entrevistados apresentando os resultados da identificação botânica das amostras coletadas nas respectivas empresas.

$\mathrm{Na}$ coleta das amostras, foi solicitado ao entrevistado que fosse fornecido mais de uma amostra da mesma madeira, caso o mesmo suspeitasse de alguma variabilidade no lote. Tal solicitação teve resposta mais acentuada entre as construtoras do que entre os distribuidores. 


\subsection{Identificação botânica das amostras de madeira coletadas}

As amostras coletadas durante as entrevistas foram identificadas no LAIM, da Divisão de Produtos Florestais - DPF, do IPT.

A identificação botânica foi realizada através do exame da anatomia do lenho. Primeiramente através do processo macroscópico, que consiste no exame com a vista desarmada e também com auxílio de uma lupa conta-fios de 10 vezes de aumento, das características organolépticas e anatômicas da madeira. Como padrões para a identificação, foram empregadas as amostras de madeiras arquivadas na Xiloteca "Calvino Mainieri" do LAIMIPT.

Se a identificação através do processo macroscópico se revelasse insuficiente, ou no caso de se tentar a obtenção da identificação a nivel de espécie, adotou-se o processo microscópico de exame das características anatômicas. Para tal, foram necessárias a execução de preparações histológicas.

No processo de identificação microscópica as lâminas histológicas das madeiras a serem identificadas foram observadas em microscópio óptico, para coleta das características anatômicas necessárias para alimentação do programa IMAC- Identificação de Madeiras Através do Computador (CHIMELO et alii, 1993). Para cada espécie identificada pelo programa, foram localizadas as respectivas lâminas histológicas disponiveis na Xiloteca "Calvino Mainieri" para a verificação final da identificação.

Caso esse procedimento se revelasse infrutifero, a identificação microscópica foi executada com apoio das descrições anatômicas existentes na literatura.

No processo de identificação, buscou-se atingir a espécie; no entanto, por ser a anatomia de madeiras um processo alternativo ao exame dos órgãos reprodutivos das árvores, isso nem sempre foi possivel. Em alguns 
casos, só foi possivel chegar ao gênero, como p. ex., Tabebuia sp. Em outros, foi indicada a espécie que mais se aproximou, mas como havia dúvida entre os identificadores utilizou-se a abreviatura cf. (de compare ou confira) interposta entre os epítetos genérico e específico, como p. ex., em Hymenolobium cf. elatum Ducke.

Com a obtenção do nome científico, através da identificação, o correspondente nome comercial foi dado, utilizando-se como critério a sugestão de "Padronização da nomenclatura comercial brasileira das madeiras tropicais amazônicas" do extinto IBDF (IBDF, 1987).

Seguindo o espírito dessa proposta de normalização (usar como nome comercial aquele mais freqüentemente usado no comércio) e, dada sua parcial desatualização, caso a madeira já esteja sendo comercialmente tratada por outro nome, este foi adotado. Como no caso da mandioqueira (Qualea spp e Ruizterania albiflora Marcano Berti) que está sendo chamada como cambará.

$\mathrm{Na}$ ausência do nome científico na norma do IBDF, foram adotados nomes constantes em publicações do IPT (MAINIERI \& CHIMELO, 1989 e MAINIERI et alii, 1983), como pinho-do-paraná para Araucaria angustifolia.

Finalmente, se o nome não contasse nesses trabalhos, foi adotado o nome pelo qual a madeira está sendo chamada no comércio (eucalipto para Eucalyptus spp e grevílea para Grevillea robusta A. Cunn., p.ex.), ou se adotou o gênero como uma designação comercial provisória, como cuningâmia para Cunninghamia lanceolata Hook e cupressus para Cupressus lusitanica Mill.

Algumas espécies de madeira pertencentes ao mesmo gênero ou mesmo a gêneros diferentes, cuja distinção na prática (características macroscópicas semelhantes) é muito difícil, foram tratadas sob um mesmo nome comercial, como p. ex.: angelim-pedra (Hymenolobium spp), 
eucalipto (Eucalyptus spp), jatobá (Hymenaea spp), cambará (Qualea spp e Ruizterania albiflora).

\subsection{Análise das informações obtidas}

O resultado das identificações das madeiras, bem como as informações coletadas nos questionários, foram tratadas conforme está descrito a seguir.

\subsubsection{Identificação botânica}

Os resultados da identificação botânica foram tabulados da seguinte maneira:

- lista das espécies de madeira identificadas, ordenada alfabeticamente pelo nome comercial;

- lista de famílias botânicas encontradas;

- verificacãa dos nomes comerciais usados pelos entrevistados: pela confrontação entre o nome comercial dado pelo entrevistado e o resultante da identificação feita em laboratório. Foram considerados nomes incorretos, aqueles que fossem mais apropriados para outras madeiras que não aquelas em que foram empregados (pinho para pinus, ipê-cumaru para cumaru, pinus para cupressus, mogno para cedro etc.). Foram considerados como sinônimos os nomes que não se enquadraram na situação descrita acima (peroba para peroba-rosa, peroba-do-norte para cupiúba, pinho para pinho-do-paraná);

- freqüência de ocorrência das madeiras: a obtenção de dados de volumes comercializados elou utilizados de madeiras é sempre uma tarefa difícil de ser realizada em função da falta de 
"disponibilidade do dado". Em função disso, buscou-se, neste trabalho, hierarquizar as madeiras apontadas no levantamento em função de um percentual de comercialização/utilização. Tal atitude revelou-se infrutífera, pois vários entrevistados não responderam a essa questão. Como alternativa, foram calculadas as freqüências percentuais de ocorrência das espécies de madeira identificadas em relação ao total de madeiras coletadas e em relação às amostras coletadas nos distribuidores e nas construtoras. Este procedimento deve ser encarado como uma forma de avaliar as madeiras mais facilmente encontradas no mercado e não com volumes comercializados/utilizados;

- fontes de suprimento: foram agrupadas as citações feitas pelos entrevistados, de acordo com o estado/região e país, no caso de importação; e

- problemas no uso/processamento das madeiras: os problemas apontados pelos entrevistados foram listados, por espécie. Essas informações devem ser encaradas apenas como meramente indicativas, pois para muitas já há soluções tecnológicas disponíveis.

\subsubsection{Informações gerais coletadas}

Tanto para os distribuidores como para as construtoras foram tabuladas as informações relativas aos seguintes itens:

- padronização das dimensões;

- padronização da qualidade das peças;

- tratamento químico preservante;

- secagem; 
- forma de aquisição da madeira;

- critérios para a escolha das madeiras (só nas construtoras); e

- problemas do setor.

\subsection{Obtenção de informações tecnológicas para as madeiras identificadas}

Para cada uma das madeiras identificadas foram coletadas informações tecnológicas para classificá-las nos grupos de uso na construção. As fontes pesquisadas foram as seguintes: IBDF (1981), SUDAM (1981), IBDF (1983), IBDF (1988), IPT (1989), MAINIERI \& CHIMELO (1989), INPA (1991), NOGUEIRA (1991) e TOMASELLI \& SILVA (1996). Além dessas fontes, foi consultado o banco de dados do Laboratório de Propriedades Físicas e Mecânicas da Madeira - LPFM, do IPT.

As informações tecnológicas pesquisadas foram as seguintes:

- densidade de massa a $15 \%$ de teor de umidade;

- flexão estática,

- máxima resistência (madeira verde),

- módulo de elasticidade (madeira verde);

- compressão axial,

- máxima resistência (madeira verde);

- cisalhamento,

- máxima resistência (madeira verde);

- dureza Janka;

- choque,

- trabalho absorvido (madeira seca ao ar);

- contrações radial, tangencial e volumétrica; 
- durabilidade natural e tratabilidade (retenção e penetração);

- fixação mecânica;

- trabalhabilidade;

- aparência;

- cor.

4.5. Critérios para agrupamento das madeiras identificadas de acordo com o uso final na construção habitacional

Os usos da madeira na construção civil habitacional foram classificados, tendo como base NAHUZ (1974) e IPT (1989), conforme é apresentado a seguir:

\section{Pesada interna:}

Peças de madeira na forma de vigas e caibros empregadas como componentes de estruturas de telhado.

2. Leve, em esquadrias:

Portas, venezianas, caixilhos etc.

3. Leve externa e leve interna estrutural:

Pontaletes, andaimes, fôrmas para concreto etc.

Partes secundárias de estruturas internas, como ripas, caibros etc.

4. Leve interna, decorativa:

Lambris, painéis, molduras, perfilados, guarnições, forros etc.

5. Leve interna, de utilidade geral:

Cordões, guarnições, rodapés etc.

6. Assoalhos domésticos:

Tacos, tábuas e parquetes. 
A alocação das madeiras nos grupos de uso final foi efetuada através de um critério onde foram consideradas as propriedades e/ou características listadas no item 4.4., julgadas necessárias para um bom desempenho da madeira.

Para cada uma das propriedades escolhidas foram fixados valores mínimos $e$, às vezes, máximos, tendo como base os valores de madeiras tradicionalmente empregadas nos usos considerados. Esta estratégia foi adotada visando fornecer uma orientação ao processo de substituição de madeiras tradicionais, ora em desenvolvimento na construção civil.

Processos de seleção de madeiras tecnicamente mais elaborados, como o apresentado por KEATING (1983), que propiciam um aproveitamento pleno das qualidades da madeira como material, demandam o desenvolvimento de estudos, normas e de estratégias de divulgação, que os tornam inviáveis para necessidades imediatas.

A seguir são apresentadas as exigências estabelecidas para cada um dos grupos de uso final na construção civil habitacional.

Além dessas exigências, também foram considerados os usos apontados no levantamento realizado nos distribuidores e construtoras. Eventuais disparidades entre os dois critérios são mencionadas nos resultados.

\section{PESADA INTERNA}

referência: peroba-rosa (Aspidosperma polyneuron Muell. Arg.)

- densidade de massa (15\% de umidade) não inferior a $710 \mathrm{~kg} / \mathrm{m}^{3}$;

- flexão estática:

- máxima resistência (madeira verde) não inferior a $84 \mathrm{MPa}$ (Mega Pascal),

- módulo de elasticidade (madeira verde) não inferior a 8700 MPa; 
- compressão axial:

- máxima resistência (madeira verde) não inferior a $39 \mathrm{MPa}$;

- cisalhamento:

- máxima resistência (madeira verde) não inferior a $10 \mathrm{MPa}$;

- durabilidade natural/tratabilidade:

- durável:

durabilidade natural não inferior a 5 anos, em contato com o solo, ou

- tratável (arseniato de cobre cromatado - CCA):

retenção não inferior a $4 \mathrm{~kg} / \mathrm{m}^{3}$, de ingrediente ativo (AWPA, 1992), e penetração total ou parcial periférica (IBDF, 1988);

- fixação mecânica:

- boa (SUDAM, 1981), ou

- fácil (INPA, 1991).

\section{LEVE, EM ESQUADRIA}

referência: pinho-do-paraná (Araucaria angustifolia (Bert.) O. Kuntze.)

- densidade de massa ( $15 \%$ de umidade) não inferior a $530 \mathrm{~kg} / \mathrm{m}^{3}$ e não superior a $840 \mathrm{~kg} / \mathrm{m}^{3}$;

- flexão estática:

- máxima resistência (madeira verde) não inferior a $57 \mathrm{MPa}$,

- módulo de elasticidade (madeira verde) não inferior a $8700 \mathrm{MPa}$;

- estabilidade dimensional:

- contrações (do ponto de saturação das fibras até $0 \%$ de umidade):

radial não superior a $4,0 \%$,

tangencial não superior a $8,0 \%$,

volumétrica não superior a $13,5 \%$,

relação T/R não superior a 2; 
- durabilidade natural/tratabilidade:

- durável:

durabilidade natural não inferior a 5 anos, em contato com o solo, ou

- tratável (CCA):

retenção não inferior a $4 \mathrm{~kg} / \mathrm{m}^{3}$, de ingrediente ativo (AWPA, 1992), e penetração total ou parcial periférica (IBDF, 1988);

- fixação mecânica:

- boa (SUDAM, 1981), ou

- fácil (INPA, 1991);

- trabalhabilidade:

- regular a muito boa (SUDAM, 1981), ou

- boa a excelente (IBDF, 1988).

\section{LEVE EXTERNA E INTERNA ESTRUTURAL}

referência: pinho-do-paraná (Araucaria angustifolia (Bert.) O. Kuntze.)

- densidade de massa ( $15 \%$ de umidade) não inferior a $530 \mathrm{~kg} / \mathrm{m}^{3}$ e não superior a $840 \mathrm{~kg} / \mathrm{m}^{3}$;

- flexão estática:

- máxima resistência (madeira verde) não inferior a $57 \mathrm{MPa}$,

- módulo de elasticidade (madeira verde) não inferior a $8700 \mathrm{MPa}$;

- compressão axial:

- máxima resistência (madeira verde) não inferior a $25 \mathrm{MPa}$;

- cisalhamento:

- máxima resistência (madeira verde) não inferior a $7 \mathrm{MPa}$;

- durabilidade natural/tratabilidade:

- durável:

durabilidade natural não inferior a 5 anos, em contato com o solo, ou 
- tratável (CCA):

retenção não inferior a $4 \mathrm{~kg} / \mathrm{m}^{3}$, de ingrediente ativo (AWPA, 1992), e penetração total ou parcial periférica (IBDF, 1988);

- fixação mecânica:

- boa (SUDAM, 1981), ou

- fácil (INPA, 1991).

\section{LEVE INTERNA, DECORATIVA}

referência: imbuia (Ocotea porosa (Nees ex. Mart.) Barroso)

- estabilidade dimensional:

- contrações (do ponto de saturação das fibras até $0 \%$ de umidade):

radial não superior a $4,0 \%$,

tangencial não superior a $8,0 \%$,

volumétrica não superior a $13,5 \%$,

relação T/R não superior a 2;

- fixação mecânica:

- boa (SUDAM, 1981), ou

- fácil (INPA, 1991);

- trabalhabilidade:

- regular a muito boa (SUDAM, 1981), ou

- boa a excelente (IBDF, 1988);

- aparência decorativa;

- cor:

as madeiras deste grupo são separadas nas seguintes cores: esbranquiçada, amarelada, acastanhada, rosada ou avermelhada, arroxeada e enegrecida. 


\section{LEVE INTERNA, DE UTILIDADE GERAL}

referência: pinho-do-paraná (Araucaria angustifolia (Bert.) O. Kuntze.)

- densidade de massa ( $15 \%$ de umidade) não superior a $700 \mathrm{~kg} / \mathrm{m}^{3}$;

- estabilidade dimensional:

radial não superior a $4,0 \%$,

tangencial não superior a $8,0 \%$,

volumétrica não superior a $13,5 \%$,

relação T/R não superior a 2;

- fixação mecânica:

- boa (SUDAM, 1981), ou

- fácil (INPA, 1991);

- trabalhabilidade:

- regular a muito boa (SUDAM, 1981), ou

- boa a excelente (IBDF, 1988).

\section{ASSOALHOS DOMÉSTICOS}

referência: peroba-rosa (Aspidosperma polyneuron Muell. Arg.)

- densidade de massa (15\% de umidade) não inferior a $710 \mathrm{~kg} / \mathrm{m}^{3}$;

- choque:

- trabalho absorvido (madeira seca ao ar) não inferior a $23 \mathrm{~J}$ (Joule);

- dureza Janka (madeira verde):

- não inferior a 6700 N (Newton);

- durabilidade natural/tratabilidade:

- durável:

durabilidade natural não inferior a 5 anos, em contato com o solo, ou

- tratável (CCA):

retenção não inferior a $4 \mathrm{~kg} / \mathrm{m}^{3}$, de ingrediente ativo (AWPA, 1992), e penetração total ou parcial periférica (IBDF, 1988); 
- estabilidade dimensional:

- contrações (do ponto de saturação das fibras até $0 \%$ de umidade):

radial não superior a $4,0 \%$,

tangencial não superior a $8,0 \%$,

volumétrica não superior a $13,5 \%$,

relação T/R não superior a 2;

- trabalhabilidade:

- regular a muito boa (SUDAM, 1981), ou

- boa a excelente (IBDF, 1988);

- fixação mecânica:

- regular a boa (SUDAM, 1981), ou

- fácil (INPA, 1991). 


\section{RESULTADOS E DISCUSSÃO}

Durante as entrevistas realizadas com 42 distribuidores de madeira, no período de 03 de setembro a 30 de outubro de 1996, e em 22 obras, no período de 23 de outubro a 18 de novembro de 1996, foram coletadas 345 amostras de madeira serrada/beneficiada que estão sendo utilizadas na construção civil habitacional na Cidade de São Paulo. Desse total, 223 amostras foram obtidas com os distribuidores de madeira e 122 com as construtoras que estão realizando as obras visitadas.

Com os resultados da identificação botânica das amostras coletadas foi realizada uma análise de suficiência amostral para verificar se o número de entrevistas realizadas era suficiente para os objetivos deste trabalho. A análise foi executada através de gráficos, para o total de visitas e para as visitas realizadas nos distribuidores e nas construtoras.

Na Figura 1 (pág. 65) é apresentado o gráfico resultante do número acumulado de espécies em função das visitas realizadas, ordenadas pela sequiência de datas, nos distribuidores e construtoras.

Da análise do gráfico apresentado pode-se verificar que a partir das entrevistas de números 49 e 50, com número acumulado de espécies de 54 e 55, respectivamente, até a última entrevista, a de número 64 , houve acréscimo de apenas três espécies de madeira diferentes.

Desta forma, a amostragem realizada foi considerada suficiente, pois qualquer acréscimo de entrevistas não resultaria num aumento importante do número de novas espécies de madeira. Para corroborar essa 
análise, a mesma distribuição foi realizada para os distribuidores (Figura 2, pág. 66) e para as construtoras (Figura 3, pág.66).

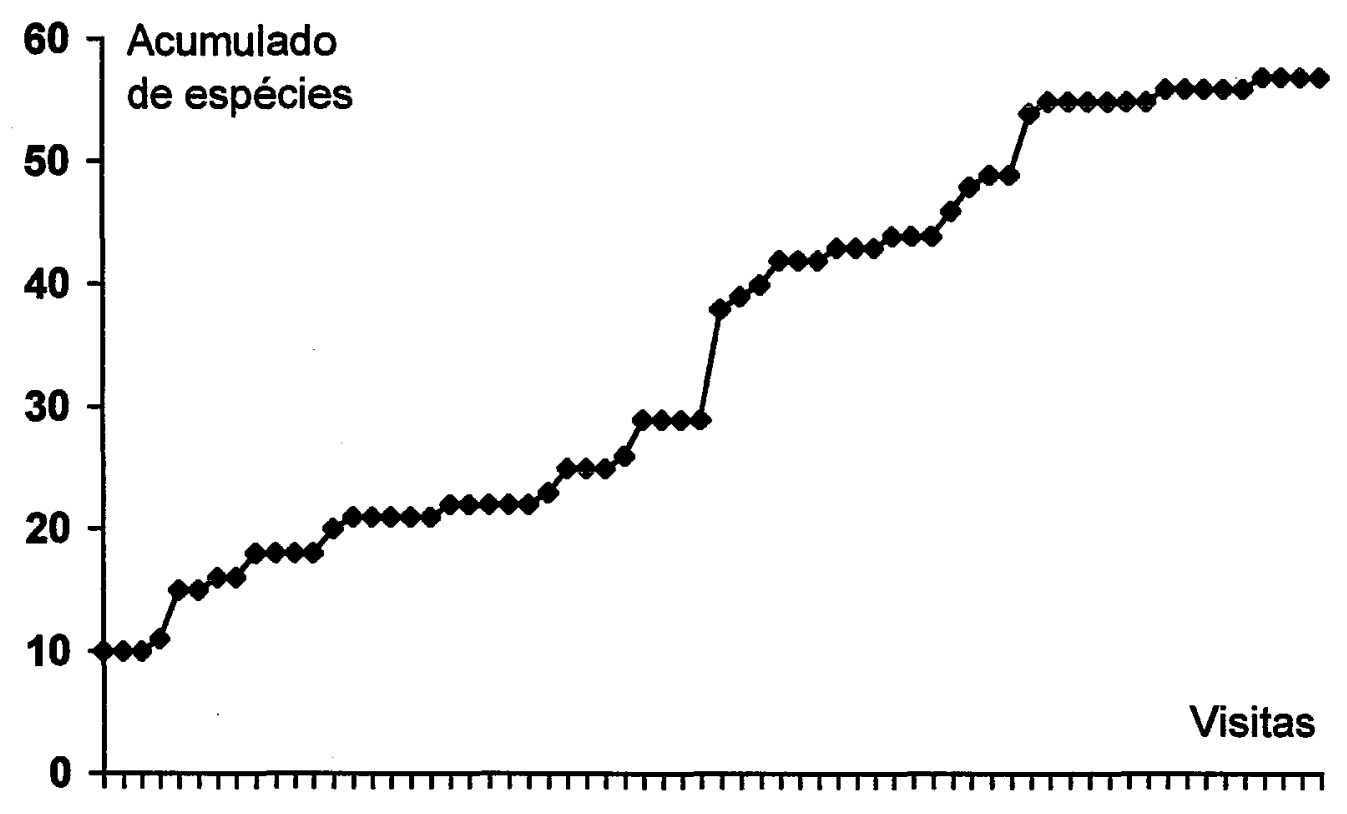

$\begin{array}{llllllllllllllll}1 & 5 & 9 & 13 & 17 & 21 & 25 & 29 & 33 & 37 & 41 & 45 & 49 & 53 & 57 & 61\end{array}$

Figura 1- Acumulado de espécies em função das visitas realizadas (por seqüência de datas) nos distribuidores e construtoras.

Na Figura 2 observa-se que a partir da visita de número 36 até a última (42), houve um acréscimo de apenas três diferentes espécies de madeira nas amostras coletadas nos distribuidores.

$\mathrm{Na}$ Figura 3 observa-se que na visita de número 14 foi alcançado o número acumulado de 30 espécies de madeira e que nas oito demais visitas houve 0 acréscimo de apenas mais quatro espécies nas amostras de madeira obtidas nas obras visitadas.

Dessa forma, esses resultados podem ser considerados semelhantes àqueles mostrados na Figura 1. 


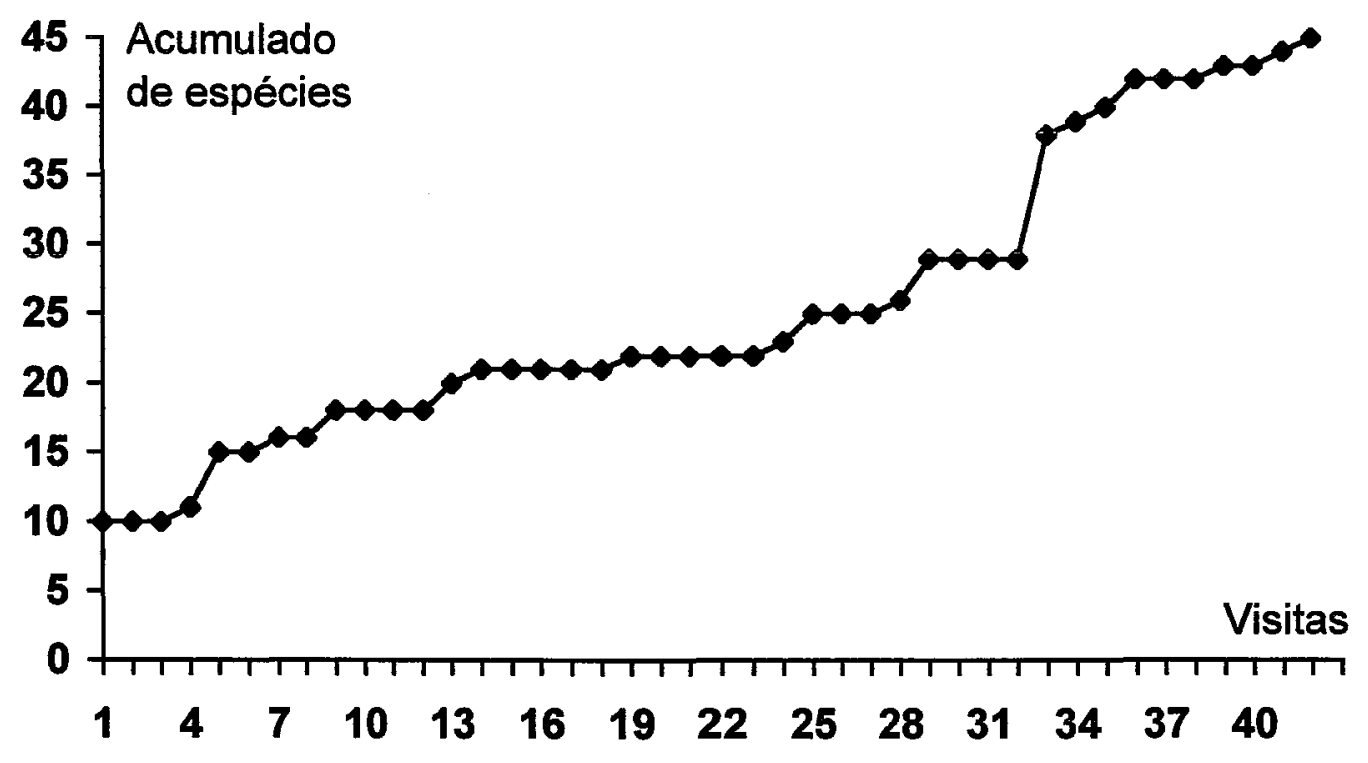

Figura 2 - Acumulado de espécies em função das visitas realizadas (por seqüência de datas) nos distribuidores.

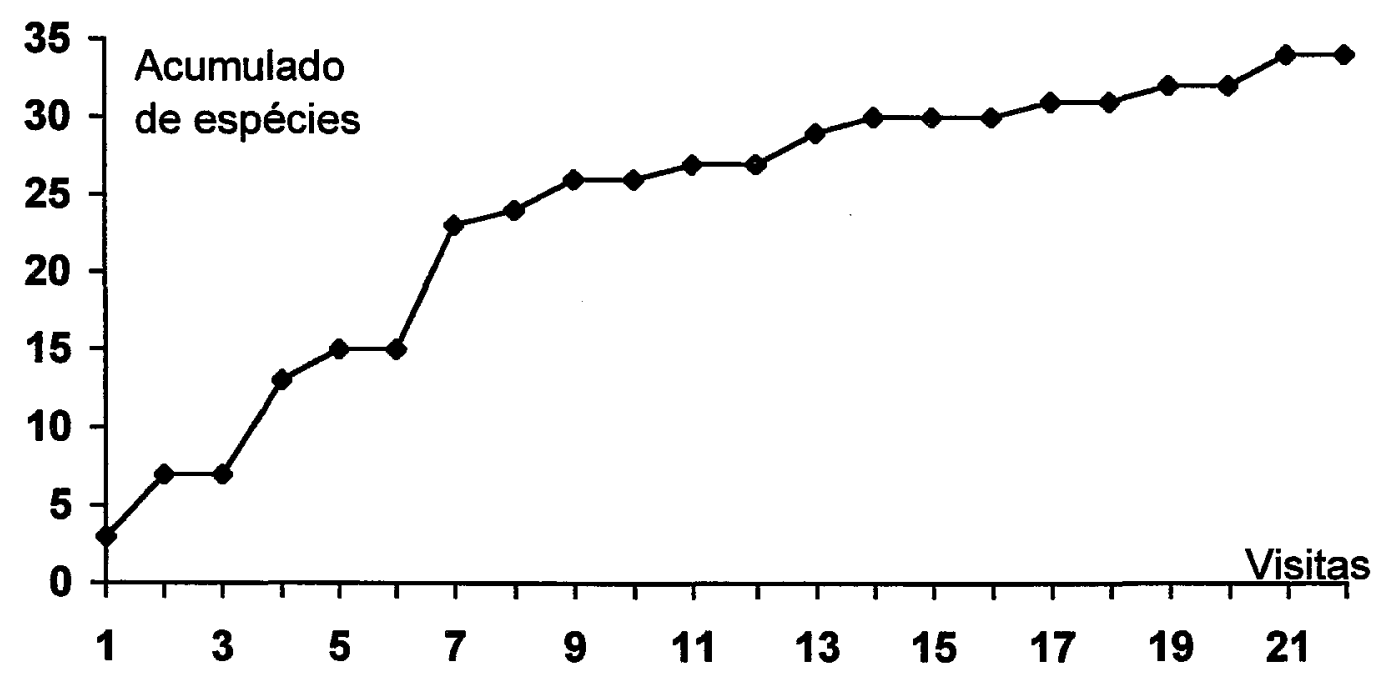

Figura 3 - Acumulado de espécies em função das visitas realizadas (por seqüência de datas) nas construtoras. 


\subsection{Identificação botânica das madeiras que estão sendo usadas na construção civil habitacional}

O exame das características do lenho dessas amostras permitiu identificá-las botanicamente e atribuir a cada amostra de madeira o seu nome científico e o respectivo nome comercial, segundo critérios mencionados na Metodologia.

No Apêndice - 3 (pág. 157) são apresentadas duas listas, uma referente às distribuidoras e a outra às construtoras, contendo os resultados da identificação botânica de todas as amostras de madeira coletadas. Para cada amostra é apresentado o seu código de coleta, o código da empresa visitada, o nome popular usado pelo entrevistado e o resultado da identificação botânica (nome comercial e científico).

Esses dados foram condensados e são apresentados na Tabela 14 (pág. 68), onde podem ser vistas as espécies de madeiras identificadas (espécie ou grupo de espécies de difícil distinção na prática), ordenadas alfabeticamente pelos seus nomes comerciais. Para cada madeira é apontado se a mesma foi detectada entre os distribuidores e/ou construtoras.

Da análise da Tabela 14, verifica-se que foram identificadas 57 espécies de madeira sendo utilizadas, na forma de madeira serrada/beneficiada, na construção civil habitacional, na Cidade de São Paulo. Entre as empresas de distribuição de madeiras foram encontradas 45 espécies de madeira, enquanto que nas construtoras esse número alcançou 34 espécies.

Do total identificado, as 22 madeiras citadas a seguir tiveram ocorrência simultânea entre distribuidores e construtoras: angelimpedra, angico-preto, angico-vermelho, cambará, canafístula, cedrinho, cedrorana, cupiúba, cupressus, eucalipto, faveira-amargosa, freijó, garapa, goiabão, ipê, jatobá, louro-canela, peroba-mica, peroba-rosa, pinho-do-paraná, pinus e quaruba (vide Tabela 14, para se obter os nomes científicos). 
Tabela 14 - Espécies de madeira identificadas nas amostras coletadas nos distribuidores e construtoras.

\begin{tabular}{|c|c|c|c|}
\hline Nome Comercial & Nome Científico & Dist. & Cons. \\
\hline amescla & $\begin{array}{l}\text { Trattinickia burserifolia Sw., } \\
\text { Burseraceae }\end{array}$ & & + \\
\hline \multirow[t]{4}{*}{ angelim-pedra } & $\begin{array}{l}\text { Hymenolobium cf. elatum Ducke, } \\
\text { Leguminosae }\end{array}$ & + & \\
\hline & $\begin{array}{l}\text { Hymenolobium cf. heterocarpum Ducke, } \\
\text { Leguminosae }\end{array}$ & + & + \\
\hline & $\begin{array}{l}\text { Hymenolobium modestum Ducke, } \\
\text { Leguminosae }\end{array}$ & + & \\
\hline & $\begin{array}{l}\text { Hymenolobium petraeum Ducke, } \\
\text { Leguminosae }\end{array}$ & & + \\
\hline angico-preto & $\begin{array}{l}\text { Anadenanthera macrocarpa (Benth.) } \\
\text { Brenae, Leguminosae }\end{array}$ & + & + \\
\hline angico-vermelho & $\begin{array}{l}\text { Parapiptadenia rigida (Benth.) Brenae, } \\
\text { Leguminosae }\end{array}$ & + & + \\
\hline bacuri & $\begin{array}{l}\text { Platonia insignis Mart., } \\
\text { Clusiaceae }\end{array}$ & & + \\
\hline bacuri-de-anta & $\begin{array}{l}\text { Moronobea coccinea Aubl., } \\
\text { Clusiaceae }\end{array}$ & & + \\
\hline $\begin{array}{l}\text { cabreúva- } \\
\text { vermelha }\end{array}$ & $\begin{array}{l}\text { Myroxylon balsamum (L.) Harms., } \\
\text { Leguminosae }\end{array}$ & + & \\
\hline \multirow[t]{4}{*}{ cambará } & $\begin{array}{l}\text { Qualea cf. homosepala Ducke, } \\
\text { Vochysiaceae }\end{array}$ & + & \\
\hline & $\begin{array}{l}\text { Qualea cf. paraensis Ducke, } \\
\text { Vochysiaceae }\end{array}$ & + & + \\
\hline & $\begin{array}{l}\text { Qualea sp, } \\
\text { Vochysiaceae }\end{array}$ & & + \\
\hline & $\begin{array}{l}\text { Ruizterania albiflora Marcano Berti, } \\
\text { Vochysiaceae }\end{array}$ & + & + \\
\hline
\end{tabular}


Tabela 14 - Espécies de madeira identificadas nas amostras coletadas nos distribuidores e construtoras (continuação).

\begin{tabular}{|c|c|c|c|}
\hline Nome Comercial & Nome Científico & Dist. & Cons. \\
\hline canafístula & $\begin{array}{l}\text { Peltophorum vogelianum Benth., } \\
\text { Leguminosae }\end{array}$ & + & + \\
\hline castanheira & $\begin{array}{l}\text { Bertholletia excelsa H. B. K., } \\
\text { Lecythidaceae }\end{array}$ & & + \\
\hline cedrinho & $\begin{array}{l}\text { Erisma uncinatum Warm., } \\
\text { Vochysiaceae }\end{array}$ & + & + \\
\hline cedro & $\begin{array}{l}\text { Cedrela sp, } \\
\text { Meliaceae }\end{array}$ & + & \\
\hline cedrorana & $\begin{array}{l}\text { Cedrelinga catenaeformis Ducke, } \\
\text { Leguminosae }\end{array}$ & + & + \\
\hline cerejeira & $\begin{array}{l}\text { Amburana acreana (Ducke) A C. Smith, } \\
\text { Leguminosae }\end{array}$ & + & \\
\hline cumaru & $\begin{array}{l}\text { Dipteryx odorata Willd., } \\
\text { Leguminosae }\end{array}$ & + & \\
\hline cuningâmia & $\begin{array}{l}\text { Cunninghamia lanceolata Hook, } \\
\text { Taxodiaceae }\end{array}$ & & + \\
\hline cupiúba & $\begin{array}{l}\text { Goupia glabra Aubl., } \\
\text { Celastraceae }\end{array}$ & + & + \\
\hline cupressus & $\begin{array}{l}\text { Cupressus lusitanica Mill., } \\
\text { Cupressaceae }\end{array}$ & + & + \\
\hline eucalipto & $\begin{array}{l}\text { Eucalyptus cf. grandis Hill ex Maiden, } \\
\text { Myrtaceae } \\
\text { Eucalyptus cf. tereticornis Sm., } \\
\text { Myrtaceae } \\
\text { Eucalyptus cf. saligna Sm., } \\
\text { Myrtaceae }\end{array}$ & + & $\begin{array}{l}+ \\
+\end{array}$ \\
\hline
\end{tabular}


Tabela 14 - Espécies de madeira identificadas nas amostras coletadas nos distribuidores e construtoras (continuação).

\begin{tabular}{|c|c|c|c|}
\hline Nome Comercial & Nome Cientifico & Dist. & Cons. \\
\hline $\begin{array}{l}\text { fava-orelha-de- } \\
\text { negro }\end{array}$ & $\begin{array}{l}\text { Enterolobium cf. schomburgkii Benth., } \\
\text { Leguminosae }\end{array}$ & & + \\
\hline faveira & $\begin{array}{l}\text { Dimorphandra cf. velutina Ducke, } \\
\text { Leguminosae }\end{array}$ & & + \\
\hline faveira-amargosa & $\begin{array}{l}\text { Vatairea cf. fusca Ducke, } \\
\text { Leguminosae } \\
\text { Vatairea cf. paraensis Ducke, } \\
\text { Leguminosae }\end{array}$ & + & + \\
\hline freijó & Cordia goeldiana Hub. Boraginaceae & + & + \\
\hline garapa & $\begin{array}{l}\text { Apuleia leiocarpa (Vog.) Macbr. } \\
\text { Leguminosae }\end{array}$ & + & + \\
\hline glícia & $\begin{array}{l}\text { Glycydendrom amazonicum Ducke, } \\
\text { Euphorbiaceae }\end{array}$ & & + \\
\hline goiabão & $\begin{array}{l}\text { Planchonella pachycarpa Pires, } \\
\text { Sapotaceae }\end{array}$ & + & + \\
\hline grevílea & $\begin{array}{l}\text { Grevillea robusta A. Cunn., } \\
\text { Proteaceae }\end{array}$ & + & \\
\hline guatambu-peroba & $\begin{array}{l}\text { Aspidosperma populifolium A . D. C., } \\
\text { Apocynaceae }\end{array}$ & & + \\
\hline imbuia & $\begin{array}{l}\text { Ocotea porosa (Nees et Mart. ex Nees.) } \\
\text { L. Barroso, } \\
\text { Lauraceae }\end{array}$ & + & \\
\hline ipê & $\begin{array}{l}\text { Tabebuia sp, } \\
\text { Bignoniaceae }\end{array}$ & + & + \\
\hline itaúba & $\begin{array}{l}\text { Mezilaurus itauba (Meissn.) Taub., } \\
\text { Lauraceae }\end{array}$ & + & \\
\hline
\end{tabular}


Tabela 14 - Espécies de madeira identificadas nas amostras coletadas nos distribuidores e construtoras (continuação).

\begin{tabular}{|c|c|c|c|}
\hline Nome Comercial & Nome Científico & Dist. & Cons. \\
\hline jacareúba & $\begin{array}{l}\text { Calophyllum brasiliense Camb., } \\
\text { Clusiaceae }\end{array}$ & + & \\
\hline jatobá & $\begin{array}{l}\text { Hymenaea cf. courbaril L., } \\
\text { Leguminosae } \\
\text { Hymenaea cf. stilbocarpa Ducke, } \\
\text { Leguminosae }\end{array}$ & $\begin{array}{l}+ \\
+\end{array}$ & + \\
\hline jutaí-cica & $\begin{array}{l}\text { Martiodendron cf. elatum (Ducke) } \\
\text { Gleason, } \\
\text { Leguminosae }\end{array}$ & + & \\
\hline louro-canela & $\begin{array}{l}\text { Ocotea sp, } \\
\text { Lauraceae }\end{array}$ & + & + \\
\hline louro-vermelho & $\begin{array}{l}\text { Nectandra rubra (Mez.) C. K. Allen, } \\
\text { Lauraceae }\end{array}$ & + & \\
\hline macacaúba & $\begin{array}{l}\text { Platymiscium cf. ulei Harms., } \\
\text { Leguminosae }\end{array}$ & + & \\
\hline maçaranduba & $\begin{array}{l}\text { Manilkara cf. longifolia (A. DC.) Dubard, } \\
\text { Sapotaceae } \\
\text { Manilkara cf. huberi Ducke, } \\
\text { Sapotaceae }\end{array}$ & $\begin{array}{l}+ \\
+\end{array}$ & \\
\hline marinheiro & $\begin{array}{l}\text { Guarea cf. grandifolia C. DC., } \\
\text { Meliaceae }\end{array}$ & + & \\
\hline marupá & $\begin{array}{l}\text { Simarouba amara Aubl., } \\
\text { Simaroubaceae }\end{array}$ & + & \\
\hline & $\begin{array}{l}\text { Swietenia macrophylla King, } \\
\text { Meliaceae }\end{array}$ & + & \\
\hline muiracatiara & $\begin{array}{l}\text { Astronium paraense, } \\
\text { Anacardiaceae } \\
\text { Astronium lecointei Ducke, } \\
\text { Anacardiaceae }\end{array}$ & & $\begin{array}{l}+ \\
+\end{array}$ \\
\hline
\end{tabular}


Tabela 14 - Espécies de madeira identificadas nas amostras coletadas nos distribuidores e construtoras (continuação).

\begin{tabular}{|c|c|c|c|}
\hline Nome Comercial & Nome Científico & Dist. & Cons. \\
\hline pau-amarelo & $\begin{array}{l}\text { Euxylophora paraensis Hub., } \\
\text { Rutaceae }\end{array}$ & + & \\
\hline pau-marfim & $\begin{array}{l}\text { Balfourodendron riedelianum Engl., } \\
\text { Rutaceae }\end{array}$ & + & \\
\hline pau-mulato & $\begin{array}{l}\text { Calycophyllum spruceanum Hook, } \\
\text { Rubiaceae }\end{array}$ & + & \\
\hline peroba-mica & $\begin{array}{l}\text { Aspidosperma cf. macrocarpon Mart., } \\
\text { Apocynaceae }\end{array}$ & + & + \\
\hline peroba-rosa & $\begin{array}{l}\text { Aspidosperma polyneuron M. Arg., } \\
\text { Apocynaceae }\end{array}$ & + & + \\
\hline pinho-do-paraná & $\begin{array}{l}\text { Araucaria angustifolia (Bert.) O . Ktze., } \\
\text { Araucariaceae }\end{array}$ & + & + \\
\hline pinus & $\begin{array}{l}\text { Pinus sp, } \\
\text { Pinaceae }\end{array}$ & + & + \\
\hline piquiarana & $\begin{array}{l}\text { Caryocar cf. glabrum (Aubl.) Pers., } \\
\text { Caryocaraceae }\end{array}$ & + & \\
\hline piquiá & $\begin{array}{l}\text { Caryocar cf. villosum (Aubl.) Pers., } \\
\text { Caryocaraceae }\end{array}$ & + & \\
\hline quaruba & $\begin{array}{l}\text { Vochysia cf. vismiaefolia Sp. Ex. Warm., } \\
\text { Vochysiaceae }\end{array}$ & + & + \\
\hline rosadinho & $\begin{array}{l}\text { Micropholis sp, } \\
\text { Sapotaceae }\end{array}$ & & + \\
\hline sucupira & $\begin{array}{l}\text { Bowdichia cf. nitida Spruce, } \\
\text { Leguminosae } \\
\text { Diplotropis cf. guianensis Benth., } \\
\text { Leguminosae }\end{array}$ & $\begin{array}{l}+ \\
+\end{array}$ & \\
\hline
\end{tabular}


Tabela 14 - Espécies de madeira identificadas nas amostras coletadas nos distribuidores e construtoras (continuação).

\begin{tabular}{llll}
\hline Nome Comercial & Nome Científico & Dist. & Cons. \\
\hline tatajuba & $\begin{array}{l}\text { Bagassa guianensis Aubl., } \\
\text { Moraceae }\end{array}$ & + & \\
tauari & $\begin{array}{l}\text { Couratari sp, } \\
\text { Lecythidaceae }\end{array}$ & + & \\
vinhático & $\begin{array}{l}\text { Plathymenia foliolosa Benth., } \\
\text { Leguminosae }\end{array}$ & + \\
\hline
\end{tabular}

Vinte e três madeiras foram encontradas somente nas distribuidoras: cabreúva-vermelha, cedro, cerejeira, cumaru, grevilea, imbuia, itaúba, jacareúba, jutaí-cica, louro-vermelho, macacaúba, maçaranduba, marinheiro, marupá, mogno, pau-amarelo, pau-marfim, pau-mulato, piquiarana, piquiá, sucupira, tatajuba e tauari.

Complementando, 12 madeiras foram identificadas somente nas construtoras: amescla, bacuri, bacuri-de-anta, castanheira, cuningâmia, fava-orelha-de-negro, faveira, glícia, guatambu-peroba, muiracatiara, rosadinho e vinhático.

Dentre as madeiras identificadas, cinco são originárias de florestas plantadas: cuningâmia, cupressus, eucalipto, grevilea e pinus. Com exceção do eucalipto e pinus, as demais madeiras não haviam sido citadas nos levantamentos anteriores consultados (RIVOLI et alii, 1978; CHIMELO, $1988^{18}$; ABPM, 1989a; IPT, 1993; MONTEIRO et alii, 1995, CORDEIRO et alii, 1995 1995;e OZÓRIO FILHO \& ALFONSO, $1995^{19}$ )

As demais 52 espécies de madeiras identificadas são procedentes de florestais nativas. Desse total, sete espécies não ocorrem ou,

${ }^{18}$ CHIMELO, J.P. (1988) op. cit.

${ }^{19}$ OZÓRIO FILHO, H.L. \& ALFONSO, V.A. (1995) op. cit. 
pelo menos, não são exploradas comercialmente na Amazônia (angico-preto, angico-vermelho, canafístula, guatambu-peroba, pau-marfim, pinho-do-paraná e vinhático); já 29 espécies são tipicamente amazônicas e outras 16 têm ampla dispersão ocorrendo tanto na Amazônia, como em outras regiões deste País e de países limítrofes. Esta constatação, sobre o paulatino aumento do número de espécies amazônicas em uso, também foi verificada por CHIMELO (1988), ABPM (1989a) e IPT (1993).

Comparando os resultados obtidos neste trabalho com aqueles apresentados pelo IBDF (1985), que detectou 250 espécies de madeira sendo processadas na Amazônia, verifica-se a existência de uma menor diversidade de espécies. Tal diferença pode ser explicada pela menor abrangência deste estudo, limitado às madeiras serradas/beneficiadas usadas na construção civil habitacional, enquanto que o outro englobou os diversos produtos de madeira gerados para atender variados tipos de usos. Outro motivo que pode ser assinalado é que o estudo do IBDF (1985) foi realizado principalmente junto aos produtores amazônicos, englobando também 0 comércio local. Esse tipo de comércio, realizado próximo às fontes de abastecimento, tipicamente comporta uma maior diversidade de espécies, 0 que aliás é uma das conclusões desse estudo.

As 14 principais espécies ou grupos de espécies de madeira detectadas pelo IBDF (vide Tabela 9, pág. 31), excetuando-se aquelas usadas na fabricação de compensados (ucuúba, muiratinga, faveiras e sumaúma), também foram identificadas neste trabalho.

O mesmo pode ser dito com relação aos dados apresentados por ABPM (1989a), vide Tabela 11 (pág. 34), excetuando-se a madeira de virola que é largamente empregada na confecção de compensados. 
Já os trabalhos de CHIMELO (1988) ${ }^{20}$ e (IPT, 1993), realizados exclusivamente para madeira serrada utilizada na confecção de estruturas de cobertura de casas de conjuntos populares (vide Tabela 10, pág. 33, e Tabela 12, pág. 36), apresentam resultados semelhantes, quanto ao número de espécies encontradas, 33 e 36 , respectivamente.

Dentre as doze madeiras que CHIMELO $(1988)^{20}$ aponta como as mais freqüentes (vide Tabela 10 , pág. 33), somente a taiúva e o guaritá não foram detectados neste trabalho.

Dentre as espécies citadas por IPT (1993), vide Tabela 12 (pág. 36), as seguintes não foram encontradas neste trabalho: abiurana, angelim-vermelho, araracanga, copaíba, guariúba, jarana, pau-jacaré, pauroxo, tanibuca, taxi, timborana e uxi.

Tal diferença, em especial a do parágrafo precedente, pode ser explicada pela metodologia empregada em ambos trabalhos. Enquanto que em IPT (1993), buscava-se, através de amostragem intensiva, identificar as madeiras empregadas nas estrutura de cobertura de casas de dois conjuntos habitacionais populares, neste trabalho os entrevistadores, embora estimulassem os entrevistados a fornecer amostras de todos os tipos de madeiras comercializadas/utilizadas, não tinham acesso ao estoque da loja ou da obra visitada, o que pode ter resultado num menor número de espécies identificadas.

Este fato, no entanto, não compromete este trabalho, pois como será visto mais adiante, ao se analisar informações mais detalhadas sobre as freqüências relativas entre as diversas madeiras identificadas, constatar-se-á que um número relativamente pequeno de espécies são as mais freqüentemente utilizadas.

${ }^{20}$ CHIMELO, J.P. (1988) op. cit. 
No entanto, no intuito de se apresentar um resultado o mais próximo possivel da realidade, as doze espécies listadas anteriormente foram incluídas nos grupamentos por uso final apresentados mais adiante, neste trabalho.

Com relação ao trabalho realizado por OZÓRIO FILHO \& ALFONSO (1995) ${ }^{21}$ que identificou 32 madeiras (vide Tabela 13, pág. 37) que estão sendo comercializadas na Cidade de São Paulo, sem se preocupar com o uso final das mesmas, apenas as seguintes espécies não foram detectadas neste trabalho: amendoim, andiroba, louro-preto, tamboril e teca.

As principais madeiras identificadas por MONTEIRO et alii (1995) e CORDEIRO et alii (1995) junto ao comércio de Piracicaba, SP, também foram detectadas neste estudo. Esses autores detectaram uma participação mais significativa de espécies originárias de florestas nativas em relação àquelas originárias de florestas plantadas, o que também foi constatado neste estudo.

Na Tabela 15 (pág. 77) observa-se que as madeiras identificadas neste trabalho pertencem a 56 gêneros de 26 familias diferentes. Dentre estas, a família Leguminosae, com 16 gêneros, é aquela que se destaca com a participação mais significativa. Tal resultado também foi obtido por OZÓRIO FILHO \& ALFONSO (1995) ${ }^{21}$, que apontam a família Leguminosae como a que mais contribui para a diversidade de gêneros e espécies.

Em seguida aparecem as famílias Vochysiaceae, com quatro gêneros, Apocynaceae, Clusiaceae, Lauraceae, Meliaceae e Sapotaceae, com três gêneros cada uma. Já as famílias Lecythidaceae e Rutaceae contribuem com dois gêneros e as demais 17 famílias participam com apenas um gênero cada uma.

${ }^{21}$ OZÓRIO FILHO, H.L. \& ALFONSO, V.A. (1995) op. cit. 
Tabela 15 - Famílias botânicas e respectiva quantidade de gêneros, das espécies de madeira identificadas.

\section{Família}

Quantidade de Gêneros

Leguminosae

16

Vochysiaceae

4

Apocynaceae, Clusiaceae, Lauraceae, Meliaceae

e Sapotaceae

Lecythidaceae e Rutaceae

Anacardiaceae, Araucariaceae, Bignoniaceae,

Boraginaceae, Burseraceae, Caryocaraceae,

Celastraceae, Cupressaceae, Euphorbiaceae,

Moraceae, Myrtaceae, Pinaceae, Proteaceae,

Rubiaceae, Sapotaceae, Simaroubaceae e

Taxodiaceae

TOTAL

56

5.1.1. Verificação da freqüência de ocorrência das espécies de madeiras identificadas.

Com vistas a detectar as madeiras mais freqüentemente identificadas nas amostras coletadas junto aos entrevistados, foi elaborada a lista constante no Apêndice 4 (pág. 167), onde são apresentadas as freqüências das madeiras identificadas na forma de valores percentuais em 
de amostras coletadas e em relação às amostras coletadas nos distribuidores e nas construtoras.

Este procedimento, conforme já mencionado na Metodologia, deve ser encarado como uma forma de se avaliar as madeiras mais facilmente encontradas no mercado e não como uma tentativa de estimar volumes comercializados/utilizados.

Com base nas informações constantes no Apêndice 4, foi elaborada a Figura 4 onde são apresentadas as dispersões entre o número de espécies de madeira (25 mais freqüentes) e a respectiva freqüência acumulada de ocorrência nos distribuidores, nas construtoras e no total.

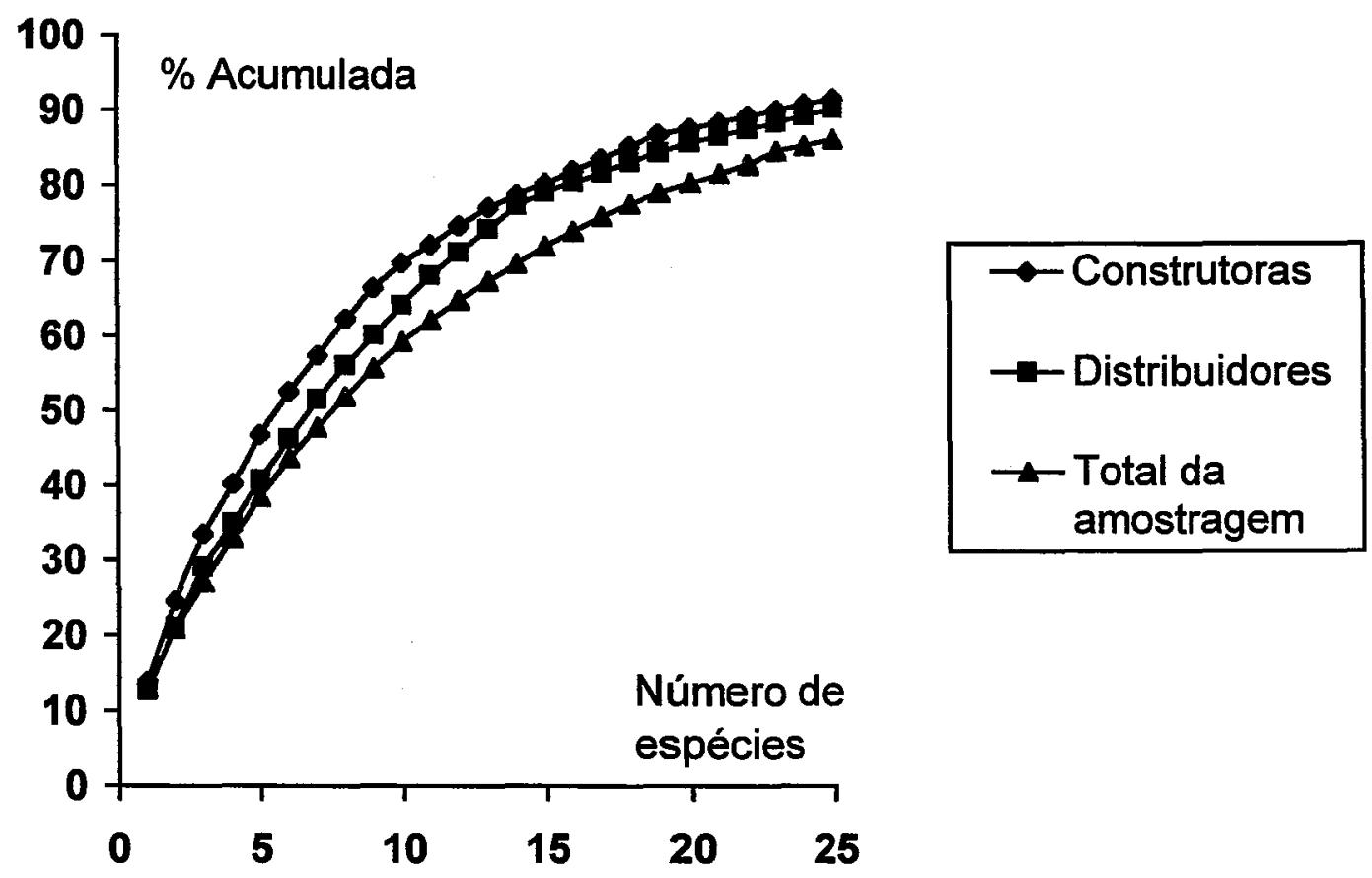

Figura 4 - Freqüência acumulada das madeiras identificadas nos distribuidores, construtoras e no total.

Da análise desse gráfico verifica-se que as cinco madeiras mais freqüentes representam percentuais que variam de cerca de 
40\% para o total de amostras, até cerca de $50 \%$ das amostras coletadas nas construtoras. Se a análise for feita para 10 madeiras, verifica-se que a freqüência varia de cerca de $60 \%$ das amostras coletadas no total, até $70 \%$ das amostras coletadas nas construtoras.

Já para 15 espécies a freqüência percentual acumulada de ocorrência das madeiras varia entre $70 \%$ e $80 \%$, restando de 20 a $30 \%$ para serem completados pelas demais espécies identificadas, que são: 30 para os distribuidores, 19 para as construtoras e 42 no total da amostragem.

$\mathrm{Na}$ Tabela 16 (pág. 80) apresentam-se as 10 espécies de madeiras com maior freqüência acumulada de ocorrência nos distribuidores, nas construtoras e para o total de amostras coletadas.

Ao se analisar essa Tabela verifica-se que o cedrinho ocupa a primeira posição nas três maneiras diferentes de se tratar as amostras coletadas, com uma freqüência percentual ao redor de 13. Tendo em vista sua utilização no grupo de uso final denominado construção civil leve externa e interna estrutural, no qual a madeira de pinho-do-paraná encontrava sua maior utilização, essa madeira pode ser considerada hoje como a que melhor substitui o pinho-do-paraná.

As madeiras de ipê, peroba-rosa, pinho-do-paraná e pinus também ocupam posição de destaque, figurando nas três colunas.

A madeira de cambará, também conhecida por mandioqueira, e a de castanheira, chamam a atenção por apresentarem freqüências de ocorrência importantes, nas construtoras, porém, em nenhuma das amostras coletadas foi apontado corretamente o nome comercial dessas madeiras. Uma das razões, provavelmente, se deve às restrições legais para a exploração da castanheira, e a outra, como será visto oportunamente, se deve a razões de comercialização, pois essas madeiras são vendidas como se fossem cedrinho. 
Tabela 16 - Relação das 10 espécies de madeira com maior freqüência de ocorrência nos distribuidores, construtoras e para 0 total de amostras coletadas.

\begin{tabular}{rlll}
\hline \multicolumn{3}{c}{$\begin{array}{c}\text { Nome Comercial (freqüência acumulada de ocorrência - \%) } \\
\text { Distribuidores }\end{array}$} & \multicolumn{1}{c}{ Construtoras } \\
\hline & & \multicolumn{1}{c}{ Total } \\
1 & cedrinho $(12,6)$ & cedrinho $(13,9)$ & cedrinho $(13,0)$ \\
2 & ipê $(21,1)$ & pinus $(24,6)$ & ipê $(20,8)$ \\
3 & mogno $(29,2)$ & cambará $(33,6)$ & pinus $(27,2)$ \\
4 & peroba-rosa $(35,0)$ & ipê $(40,2)$ & pinho-do-paraná $(33,0)$ \\
5 & imbuia $(40,8)$ & pinho-do-paraná $(46,8)$ & peroba-rosa $(38,5)$ \\
6 & pinho-do-paraná $(46,2)$ & castanheira $(52,5)$ & mogno $(43,7)$ \\
7 & jatobá $(51,6)$ & peroba-rosa $(57,4)$ & cambará $(47,8)$ \\
8 & cerejeira $(56,1)$ & cupiúba $(62,3)$ & jatobá $(51,9)$ \\
9 & pinus $(60,1)$ & angelim-pedra $(66,4)$ & imbuia $(55,7)$ \\
10 & cedro $(64,1)$ & amescla $(69,7)$ & angelim-pedra $(59,2)$ \\
& outras 35 madeiras & outras 24 madeiras & outras 47 madeiras \\
& $(100,0)$ & $(100,0)$ & $(100,0)$ \\
\hline
\end{tabular}

Os resultados obtidos sugerem que, a exemplo do que foi apontado por IBDF (1985), CHIMELO (1988) 22 e ABPM (1989a), a grande diversidade de espécies encontrada nas florestas se reflete no comércio de madeiras, porém um número não superior a 15 madeiras é responsável por cerca de $80 \%$ das madeiras comercializadas.

${ }^{22}$ CHIMELO, J.P. (1988) op. cit. 
Apesar do processo de escassez crescente das madeiras de peroba-rosa e, principalmente, do pinho-do-paraná, essas madeiras ainda desempenham um papel importante na construção, conforme mostrado por ABPM (1989a) e por este trabalho.

Dentre as madeiras de reflorestamento detectadas no levantamento, somente a madeira de pinus apresentou ocorrência significativa. Isso corrobora a afirmação feita por IBAMA/FUNATURA (1995) de que a utilização em larga escala da madeira gerada em reflorestamentos, na construção civil, requer a superação de alguns problemas tecnológicos e de aceitação por parte dos consumidores. Adicionalmente, ainda segundo essa fonte, há a necessidade de investimentos para a formação de novas florestas para atender a demanda futura de matéria-prima.

\subsubsection{Verificação dos nomes comerciais das madeiras usados pelos entrevistados.}

Pela comparação entre o nome comercial apontado na identificação botânica das amostras de madeira e aquele fornecido pelos entrevistados foram obtidos os resultados apresentados na Tabela 17 (pág. 82).

Nessa Tabela observa-se que, para o total de amostras coletadas, $29 \%$ delas tiveram seus nomes comerciais apontados de forma incorreta pelos entrevistados. Ao se analisar as identificações desagregadas em distribuidores e construtoras, verifica-se que o percentual de erro entre os distribuidores foi de 12 , ao passo que nas construtoras esse valor alcançou $61 \%$.

Tal diferença acentuada pode ser explicada pela solicitação feita ao entrevistado para que fornecesse mais de uma amostra de uma mesma madeira, caso ele suspeitasse de alguma variabilidade no lote de 
madeira em estoque. Essa solicitação foi atendida quase que exclusivamente pelas construtoras.

Tabela 17 - Verificação do uso dos nomes comerciais pelos entrevistados

\begin{tabular}{|c|c|c|c|c|c|}
\hline & \multirow{3}{*}{ Amostras Coletadas } & \multicolumn{4}{|c|}{ Nome Comercial } \\
\hline & & \multicolumn{2}{|c|}{ Correto } & \multicolumn{2}{|c|}{ Incorreto } \\
\hline & & un. & $\%$ & un. & $\%$ \\
\hline Distribuidores & 223 & 197 & 88 & 26 & 12 \\
\hline Construtoras & 122 & 48 & 39 & 74 & 61 \\
\hline Total & 345 & 245 & 71 & 100 & 29 \\
\hline
\end{tabular}

Na Tabela 18 (pág.83) são apresentados os casos em que houve erro no uso dos nomes comerciais pelos distribuidores. Observa-se que as madeiras em que foi mais freqüente a identificação incorreta foram o mogno e jutaí-cica, com três erros cada uma, seguidas pelo cambará, cedrinho, cedrorana e cumaru, com dois erros cada uma.

Na Tabela 19 (pág. 84) são apresentados os casos em que houve erro no uso dos nomes comerciais pelas construtoras. Nesta Tabela já se observa a incidência mais destacada de erros nas seguintes espécies: cambará (11), castanheira (7), angelim-pedra (5), pinus (5), amescla (4), pinhodo-paraná (4), eucalipto (3) e muiracatiara (3).

A Tabela 20 (pág. 86) mostra a informação apresentada na Tabela 19, porém, ordenada de forma diferente a fim de se destacar quais nomes foram mais utilizados impropriamente pelas construtoras.

Nessa Tabela pode ser visto que o nome comercial cedrinho foi aplicado erroneamente em 32 situações, ou seja, $43 \%$ dos erros 
detectados entre as construtoras. Esse nome foi aplicado a 15 diferentes espécies de madeira.

Tabela 18 - Nomes comerciais errados fornecidos pelos distribuidores.

\begin{tabular}{|c|c|c|}
\hline \multicolumn{2}{|c|}{ Nome Comercial } & \multirow{2}{*}{$\begin{array}{l}\text { Quantidade } \\
\text { de Erros }\end{array}$} \\
\hline Identificado & Coletado & \\
\hline jutaí-cica & jatobá e muiracatiara & 3 \\
\hline mogno & cedro-rosa e jatobá & 3 \\
\hline cambará & $\begin{array}{l}\text { cedrinho, abiurana, goiabão e peroba- } \\
\text { do-norte }\end{array}$ & 2 \\
\hline cedrinho & mogno e peroba-do-norte & 2 \\
\hline cedrorana & cedro-rosa e cedrinho & 2 \\
\hline cumaru & ipê-cumaru e sucupira & 2 \\
\hline angico-vermelho & peroba-do-norte & 1 \\
\hline cerejeira & imbuia & 1 \\
\hline cupressus & pinho-reflorestado & 1 \\
\hline faveira-amargosa & angelim & 1 \\
\hline garapa & perobinha & 1 \\
\hline jacareúba & mogno-marinheiro & 1 \\
\hline jatobá & angico-preto & 1 \\
\hline louro-canela & imbuia & 1 \\
\hline marinheiro & canjerana & 1 \\
\hline peroba-mica & peroba-rosa & 1 \\
\hline piquiá & abiurana, goiabão e peroba-do-norte & 1 \\
\hline quaruba & cedrinho & 1 \\
\hline
\end{tabular}


Tabela 19 - Nomes comerciais errados fornecidos pelas construtoras.

\begin{tabular}{|c|c|c|}
\hline \multicolumn{2}{|c|}{ Nome Comercial } & \multirow{2}{*}{$\begin{array}{c}\text { Quantidade } \\
\text { de Erros }\end{array}$} \\
\hline Identificado & Coletado & \\
\hline cambará & cedrinho, cupiúba & 11 \\
\hline castanheira & cedrinho e pinus & 7 \\
\hline angelim-pedra & cupiúba, cedrinho e desconhecida & 5 \\
\hline pinus & pinho, cedrinho, pinho-de-segunda & 5 \\
\hline amescla & cedrinho, pinho e desconhecido & 4 \\
\hline pinho-do-paraná & pinus e desconhecido & 4 \\
\hline eucalipto & cedrinho, peroba-rosa e pinho & 3 \\
\hline muiracatiara & cedrinho & 3 \\
\hline bacuri-de-anta & cupiúba e perobinha-do-campo & 2 \\
\hline cedrinho & cupiúba e desconhecido & 2 \\
\hline cedrorana & cedrinho & 2 \\
\hline cuningâmia & pinus e pinho & 2 \\
\hline freijó & pinho e desconhecido & 2 \\
\hline ipê & desconhecido & 2 \\
\hline jatobá & cedrinho e ipê & 2 \\
\hline vinhático & desconhecido & 2 \\
\hline angico-preto & peroba & 1 \\
\hline angico-vermelho & peroba & 1 \\
\hline bacuri & cupiúba & 1 \\
\hline canafístula & cupiúba & 1 \\
\hline cupiúba & peroba & 1 \\
\hline
\end{tabular}


Tabela 19 - Nomes comerciais errados fornecidos pelas construtoras (continuação).

\begin{tabular}{|c|c|c|}
\hline \multicolumn{2}{|c|}{ Nome Comercial } & Quantidade \\
\hline Identificado & Coletado & de Erros \\
\hline cupressus & pinho & 1 \\
\hline fava-orelha-de-negro & cedrinho & 1 \\
\hline faveira & cedrinho & 1 \\
\hline faveira-amargosa & cedrinho & 1 \\
\hline garapa & cupiúba & 1 \\
\hline glícia & cedrinho & 1 \\
\hline goiabão & peroba & 1 \\
\hline louro-canela & cupiúba & 1 \\
\hline peroba-mica & peroba & 1 \\
\hline quaruba & cedrinho & 1 \\
\hline rosadinho & cedrinho & 1 \\
\hline
\end{tabular}

Outra situação, que pode ser observada na Tabela 20, é o alto número de amostras coletadas em que o entrevistado desconhecia o nome da madeira.

Ainda merecem destaque os nomes comerciais cupiúba, pinho, peroba e pinus, que, no conjunto, foram utilizados de forma errada em 27 ocasiōes. 
Tabela 20 - Nomes comerciais errados fornecidos pelas construtoras

\begin{tabular}{|c|c|c|}
\hline \multicolumn{2}{|c|}{ Nome Comercial } & \multirow{2}{*}{$\begin{array}{l}\text { Quantidade } \\
\text { de Erros }\end{array}$} \\
\hline Coletado & Identificado & \\
\hline \multirow[t]{6}{*}{ cedrinho } & amescla, angelim-pedra, & \\
\hline & cambará, castanheira, cedrorana, & \\
\hline & eucalipto, fava-orelha-de-negro, & 32 \\
\hline & faveira, faveira-amargosa, glícia, & \\
\hline & jatobá, muiracatiara, pinus, & \\
\hline & quaruba e rosadinho & \\
\hline \multirow[t]{3}{*}{ desconhecido } & amescla, angelim-pedra, & \\
\hline & cedrinho, freijó, ipê, pinho-do- & 11 \\
\hline & paraná, e vinhático & \\
\hline \multirow[t]{3}{*}{ cupiúba } & angelim-pedra, bacuri, bacuri-de- & \\
\hline & anta, cambará, canafístula, & 9 \\
\hline & cedrinho, garapa e louro-canela & \\
\hline \multirow[t]{2}{*}{ pinho } & amescla, cuningâmia, cupressus, & \\
\hline & eucalipto, freijó e pinus & 9 \\
\hline \multirow[t]{2}{*}{ peroba } & angico-preto, angico-vermelho, & \\
\hline & cupiúba, goiabão e peroba-mica & 5 \\
\hline \multirow[t]{2}{*}{ pinus } & castanheira, cuningâmia, pinho- & \\
\hline & do-paraná & 4 \\
\hline ipê & jatobá & 1 \\
\hline peroba-rosa & eucalipto & 1 \\
\hline perobinha-do-campo & bacuri-de-anta & 1 \\
\hline pinho-de-segunda & pinus & 1 \\
\hline
\end{tabular}


O uso de nomes impróprios para as madeiras já foi abordado de forma abrangente por IBDF (1985). Segundo esse estudo há três razões que podem gerar o uso de nomes incorretos:

- presença de caracteristicas semelhantes entre madeiras diferentes (cor e densidade de massa);

- uso de nomes de espécies já conhecidas visando facilitar a comercialização; e

- uso de uma característica da madeira para designar o seu nome.

IBDF (1985) menciona ainda que, em algumas situações, não há uma causa aparente para indução ao erro, e que o mesmo poderia ser atribuído à falha na coleta da informação.

Tais causas podem explicar boa parte dos erros no uso de nomes comerciais encontrados neste estudo; no entanto, como entender os erros cometidos com a madeira de cedrinho, onde madeiras com densidades de massa e cores distintas (fava-orelha-de-negro, faveiras, angelim-pedra) foram confundidas com o mesmo?

Uma explicação para esse fato pode estar relacionada a um processo de substituição dessa madeira, por um grupo de espécies, nativas ou não, em um uso que se caracteriza como temporário (andaimes, fôrmas para concreto, pontaletes etc.), classificado, neste estudo, como "leve externo", onde as construtoras buscam, além do bom desempenho do material, o menor custo possível na aquisição do mesmo.

O lado positivo dessa verificação seria a constatação da aplicação prática do conceito de grupamento de espécies por uso final. Por outro lado, esse grupamento é realizado por tentativa e erro, em função da disponibilidade das madeiras, o que pode reforçar o preconceito em relação ao mau desempenho da madeira como material de construção. 


\subsubsection{Fontes de suprimento.}

As informações apresentadas a seguir, a exemplo da análise sobre freqüência de ocorrência das madeiras, não devem ser confundidas com estimativas de volume de madeira comercializada.

As fontes de suprimento das madeiras coletadas nos distribuidores, segundo informações dos entrevistados, são apresentadas na Tabela 21 (pág. 89), onde pode ser visto que a Região Amazônica alcançou $61 \%$ do total de citações, seguida pela Região Sul, com 13\% (pinho-do-paraná, pinus, imbuia e peroba-rosa). Foi também mencionado que, em $5 \%$ das citações, a madeira era adquirida na Região Sul, porém era originária de outra região (cedrinho e mogno, p. ex.).

A Região Sudeste foi citada como fonte de suprimento em $2 \%$ (eucalipto e pinus), enquanto o Paraguai foi citado em $5 \%$ dos casos (peroba-rosa, jatobá, pau-marfim e angico-preto). Em 14\% das citações os entrevistados não souberam indicar as fontes de suprimento.

Ainda na Tabela 21 pode ser visto que os Estados de Rondônia, Pará e Mato Grosso, foram os mais citados como fontes de suprimento. Com participação menor, porém importante, aparecem os Estado do Paraná e Santa Catarina, da Região Sul.

A ABPM (1989a) informa que o setor de revendas (distribuidores, neste estudo) se abastecia principalmente com produtos oriundos da Região Sul ( $52 \%$ do total) e das Regiões Norte e Centro-Oeste $(46,1 \%)$. Como a Região Centro-Oeste possui áreas amazônicas e não amazônicas, não é possível comparar diretamente os resultados.

Na Tabela 22 (pág. 90) são apresentadas as informações referentes às construtoras. Nessa Tabela pode ser visto que em $52 \%$ das citações os informantes não conheciam as fontes de suprimento das madeiras que estavam sendo utilizadas. Isto se deve, provavelmente, ao fato de que os 
entrevistados que prestaram as informações, em geral o engenheiro-residente ou o mestre-de-obras, não terem acesso às informações sobre a aquisição do material.

Embora com essa restrição, pode-se verificar, na Tabela 22, que o Mato Grosso, com $13 \%$ das citaçōes, é a fonte de suprimento mais mencionada. No mesmo nível aparece a Região Sudeste como fonte de aquisição de madeiras originárias de outras regiões.

Tabela 21 - Fontes de suprimento citadas pelos distribuidores.

Amazônia

61

geral

Acre 3

Maranhão 6

Mato Grosso 12

Pará 14

Rondônia 19

$\begin{array}{ll}\text { Sul } & 13\end{array}$

Geral 1

Paraná $\quad 7$

Santa Catarina $\quad 5$

Sudeste 2

Minas Gerais 1

São Paulo 1

Outra regiōes, via Sul 5

Paraguai 5

Não sabe 14 
Tabela 22 - Fontes de suprimento citadas pelas construtoras.

Fontes de Suprimento

Percentagem de Citações

Amazônia

Mato Grosso

Pará

Centro-Oeste

Goiás

Sul

Paraná

Outra regiões, via Sudeste

Outra regiões, via Sul

A ABPM (1989a) menciona que o setor de engenharia (construtoras neste estudo) se abastecia com produtos oriundos principalmente da Região Norte $(52,9 \%)$ e das Regiões Sul e Centro-Oeste (45,6\%).

Embora com as restrições mencionadas anteriormente, pode-se afirmar que a Região Sul ainda desempenha um papel importante no abastecimento do mercado de madeira serrada/beneficiada para uso na construção civil habitacional na Cidade de São Paulo, quer gerando madeira serrada, quer beneficiando madeiras provenientes de outras regiōes.

A outra fonte importante de madeira serrada/beneficiada é a Amazônia que, mantidas as condições atuais de pouca utilização de madeiras oriundas de reflorestamentos, deverá ter uma participação cada vez mais significativa no mercado de madeira serrada da Cidade de São Paulo. 


\subsubsection{Problemas com as madeiras.}

Visando captar a experiência prática dos entrevistados, foi solicitado que os mesmos apresentassem informações sobre a trabalhabilidade, fixação mecânica e desempenho em uso das madeiras que estão sendo utilizadas na construção civil habitacional na Cidade de São Paulo. As informações obtidas serão utilizadas quando da alocação das madeiras nos grupos de usos finais.

Foram também mencionados problemas com algumas madeiras, que são relatados a seguir. Essas informações devem ser encaradas como meramente indicativas, visto que muitos dos problemas podem ser contornados com soluções tecnológicas já disponíveis.

- angelim-pedra:

secagem com defeitos, necessita cuidados no acabamento para se evitar manchas na aplicação do verniz;

- angico-preto:

muito dura, problemas na secagem, peças grandes empenam, variação da cor;

- cabreúva-vermelha:

oleosidade impede a aplicação de verniz e "sinteko";

- cedro:

fixação mecânica ruim, baixa durabilidade no uso externo e serragem provoca irritações nas vias respiratórias (nariz);

- cerejeira:

problemas na secagem (rachas),

baixa durabilidade (apodrece); 
- cumaru:

difícil de trabalhar quando seca,

movimenta em uso;

- cuningâmia:

fixação ruim;

- cupressus:

durabilidade menor que a do pinho-do-paraná;

- eucalipto:

baixa durabilidade no solo;

- freijó:

arrepia no acabamento;

- garapa:

mancha na aplicação do "sinteko", escurece;

- goiabão:

trinca em uso, em locais muito ventilados;

- imbuia:

problemas de secagem (empena), variação de cor, madeira revessa;

- ipê:

muito dura;

- itaúba:

desgaste de ferramentas, secagem demorada, racha muito;

- jatobá:

racha e empena em uso, variação de cor, difícil de serrar, pesada;

- maçaranduba:

difícil de encontrar;

- macacaúba:

madeira desconhecida do usuário; 
- marinheiro:

muito alburno

- mogno:

escassa, preço alto, fixação ruim;

- pau-marfim:

empena, apresenta muitos nós, furos de insetos e manchas, falta resistência mecânica para assoalho;

- peroba-rosa:

empena;

- pinho-do-paraná:

preço alto, não resiste a cupim, apodrece;

- pinus:

não resiste a cupim, forro empena, presença de nós, quebra, fixação mecânica ruim;

- tauari:

fraca (para assoalhos), cor variável, difícil selecionar.

Segundo o IBDF (1985) a presença de características indesejáveis na madeira e/ou o desconhecimento ou a não utilização de tecnologia adequada de processamento dessas espécies, são fatores importantes que restringem a expansão do uso mais intensivo das madeiras tropicais amazônicas. Portanto, ações de divulgação tecnológica e de treinamento de mão-de-obra são indicadas para minimizar essa deficiência do setor produtivo.

\subsection{Informações gerais coletadas nos distribuidores e construtoras}

Além das informações e amostras de madeira coletadas, foram obtidas, nos distribuidores e construtoras, outras informações gerais 
referentes aos seguintes itens: padronização das dimensões e da qualidade das peças, tratamento químico preservante, secagem, forma de aquisição da madeira, critério para a escolha das espécies de madeira (só para as construtoras) e problemas do setor.

\subsubsection{Padronização das dimensões}

Nas empresas visitadas foi perguntado se as dimensões das peças de madeira serradas/beneficiadas, comercializadas/utilizadas, eram padronizadas ou não. No caso da resposta afirmativa foi solicitado informar qual era a padronização empregada. Os resultados obtidos para essas questões são apresentados na Tabela 23.

Tabela 23 - Padronização das dimensões das peças de madeira serrada e beneficiada, nos distribuidores e construtoras.

\begin{tabular}{lcccc}
\hline & \multicolumn{2}{c}{ Distribuidores } & \multicolumn{2}{c}{ Construtoras } \\
& $\mathrm{n}^{\circ}$ & $\%$ & $\mathrm{n}^{\circ}$ & $\%$ \\
\hline Não & 6 & 14 & 7 & 32 \\
Sim & 36 & 86 & 15 & 68 \\
Total & 42 & 100 & 22 & 100 \\
\hline
\end{tabular}

Nessa Tabela observa-se que $14 \%$ dos distribuidores responderam que não utilizam nenhuma padronização das peças, enquanto outros $86 \%$ afirmaram que as peças comercializadas seguem uma padronização. 
Entre as construtoras, $32 \%$ responderam que não adotam medidas padronizadas, enquanto outras $68 \%$ trabalham com medidas padronizadas.

Em ambos os casos, nenhum entrevistado citou a utilização de uma norma ou especificação de entidades de classe e de instituições normalizadoras.

Quando solicitados a dizer qual é a padronização adotada, 34 distribuidores de madeira disseram adotar as dimensões comerciais ou de mercado. Outros 22 disseram atender a pedidos especiais além de fornecer peças de dimensões comerciais.

Diversos entrevistados apontaram vários nomes para peças de madeira serrada/beneficiada, de acordo com suas dimensões nominais (espessura $x$ largura), conforme é apresentado a seguir:

- coluna (cm): 20,0 x 30,0;

- dormente $(\mathrm{cm}): 16,0 \times 22,0$ e $17,0 \times 24,0$;

- viga (cm): $5,0 \times 6,0,6,0 \times 12,0,6,0 \times 16,06,0 \times 20,0$, $6,0 \times 25,0$ e $6,0 \times 30,0$;

- caibro:

(cm): $2,5 \times 5,0,4,0 \times 4,0,5,0 \times 5,0,5,0 \times 6,0,6,0 \times 8,0$, $7,0 \times 8,0,7,5 \times 7,5$, $($ polegada $=$ pol $): 3 \times 3$;

- pontalete:

(cm): $4,0 \times 4,0,7,0 \times 7,0,7,5 \times 7,5$ e $8,0 \times 8,0$ (pol): $3 \times 3$, roliço (diâmetro) (cm): 15,0;

- barrote (cm): 2,0 x 5,0;

- pranchas:

espessura (cm): 5,0 e 6,0, espessura (pol): 2, 
largura (cm): $15,0,20,0,25,0$ e 30,0 ,

largura (pol): 8;

- tabeira (cm): $2,5 \times 20,02,5 \times 15,0$ e $2,5 \times 20,0$;

- tábua:

espessura (cm): 1,5, 2,0 e 2,5,

espessura (pol): 1 ,

largura (cm): 5,0,10,0,12,0,15,0, 20,0, 22,0, 25,0,30,0 e 32,0 ,

largura (pol): 8, 9, 10 e 12;

- $\operatorname{ripa}(\mathrm{cm}): 0,5 \times 5,0,1,0 \times 5,0,1,5 \times 5,0,1,5 \times 5,5$ e $2,5 \times 5,0$;

- sarrafo:

espessura (cm): 2,0 e 2,5,

espessura (pol): 1 ,

largura (cm): 2,0, 5,0,7,0,10,0 e 15,0,

largura (pol): 3 e 4 ,

- tábua para assoalho $(\mathrm{cm}): 2,0 \times 20,0,2,0 \times 15,0,2,5 \times 15,0$, $2,5 \times 20,0,3,0 \times 25,0$ e $3,0 \times 28,0$;

- taco (largura $x$ comprimento) (cm): 7,0 x 21,0, 7,0 × 35,0, $7,0 \times 42,0,10,0 \times 40,0$ e 10,0 x 50,0;

- deque $(\mathrm{cm}): 2,0 \times 10,0$ e $2,5 \times 10,0$;

- degrau (cm): $3,0 \times 30,0$;

- forro:

espessura (cm): 0,9, 1,0, 1,2 e 2,5,

largura (cm): $9,0,10,0$ e 10,5;

- lambril:

espessura (cm): 1,0 e 1,5,

largura (cm): $9,5,10,0$ e 15,0; 
- guarnição:

espessura $(\mathrm{cm}): 1,0$ e 1,5,

largura $(\mathrm{cm}): 4,5,5,0,6,5$ e 7,0;

- rodapé $(\mathrm{cm}): 2,0 \times 20,0$;

- cordão (cm): $1,5 \times 15,0$;

- balaustre $(\mathrm{cm}): 7,0 \times 7,0$;

- porta (altura x largura) (m): $2,10 \times 0,62,2,10 \times 0,72,2,10 x$ $0,82,2,10 \times 0,92,2,11 \times 0,60,2,11 \times 0,70$ e $2,11 \times 0,80$;

- janela (altura $\times$ largura) (m): 1,2 × 1,2, 1,4 ×1,4, 1,25 x 1,25, $1,25 \times 1,45$

- batente (cm): $3,5 \times 14,0,3,5 \times 15,0,3,5 \times 16,0,3,5 \times 18$, $3,5 \times 20,0,3,5 \times 25,0,4,0 \times 14,0,4,0 \times 20,0$ e $4,0 \times 25,0$.

Foram feitas também diversas citações de bitolas (largura $x$ espessura) sem nenhum nome especifico $(\mathrm{cm}): 1,0 \times 2,0,1,0 \times 4,0,1,0 \times 5,0$, $1,0 \times 6,0,1,0 \times 8,0,1,0 \times 9,0,1,0 \times 12,0,1,5 \times 12,0,2,0 \times 2,0,2,0 \times 10,0$, $2,0 \times 12,0,3,0 \times 3,0,5,0 \times 12,0,20,0 \times 20,0,20,0 \times 30,0$ e $30,0 \times 30,0$.

A análise dessas informações revela uma grande quantidade de dimensões disponiveis, uma confusão com relação aos nomes das peças (caibros com pontaletes, tábuas estreitas e sarrafos etc.) e o uso do sistema imperial de medidas (polegada), notadamente nas espessuras das peças.

A ABPM (1989a) menciona que uma das principais reclamações do setor de engenharia (construção civil) está relacionada com a ausência de padronização das dimensões e da qualidade das peças de madeira serrada.

Durante as visitas realizadas, alguns entrevistados queixaram-se das dimensões inadequadas das peças que acabam provocando desperdícios. 
Segundo FRANCO $(1996)^{23}$, a Associação Brasileira de Normas Técnicas - ABNT está elaborando uma norma especifica para padronizar as dimensões das peças de madeira serrada. Após a votação e efetivação da norma, será de muita valia que a mesma seja empregada efetivamente e sofra as adequações necessárias.

\subsubsection{Padronização da qualidade}

Foi levantado se as empresas entrevistadas utilizam algum critério padronizado para a qualidade das peças de madeira serrada/beneficiada. No caso de resposta afirmativa foi solicitado informar qual era a padronização empregada. Os resultados obtidos para essas questões são apresentados na Tabela 24.

Tabela 24 - Padronização da qualidade das peças de madeira serrada e beneficiada, nos distribuidores e construtoras.

\begin{tabular}{lcccc}
\hline & \multicolumn{2}{c}{ Distribuidores } & \multicolumn{2}{c}{ Construtoras } \\
& $\mathrm{n}^{\mathrm{o}}$ & $\%$ & $\mathrm{n}^{\mathrm{o}}$ & $\%$ \\
\hline \multirow{2}{*}{ Não } & 10 & 24 & 11 & 50 \\
Sim & 32 & 76 & 11 & 50 \\
Total & 42 & 100 & 22 & 100 \\
\hline
\end{tabular}

${ }^{23}$ FRANCO, N. (IPT. Laboratório de Propriedades Físicas e Mecânicas da Madeira) Comunicação Pessoal, 1996. 
Na Tabela 24 verifica-se que $24 \%$ dos distribuidores responderam que não há nenhuma padronização da qualidade sendo aplicada nas peças por eles comercializadas. De outro lado, $76 \%$ declaram que há essa padronização. Quando perguntados qual é a padronização utilizada, responderam que só vendem madeira classificada como: primeira, primeira e segunda, boa qualidade, só cerne, exportação e comercial. Outros responderam que classificam as peças considerando: presença de defeitos, dimensões e dimensões e defeitos.

Para as construtoras, ainda na Tabela 24, verifica-se que as respostas "não" e "sim" se eqüivalem. Aqueles que disseram aplicar uma padronização de qualidade citaram que só utilizam madeira classificada como: primeira, primeira e segunda, segunda e terceira industrial.

Nenhum dos entrevistados mencionou a utilização de norma e/ou especificações que definam as classes de qualidade mencionadas.

A existência de definições precisas de termos e de especificações de dimensōes e qualidade é reconhecida internacionalmente como uma das exigências básicas para o desenvolvimento racional do comércio de madeiras (ZENID, 1990). No Brasil, a classificação de madeira serrada foi praticada largamente somente com a madeira de pinho-do-paraná, destinada aos mercados domésticos e internacionais. Atualmente, a despeito da existência de normas para pinus e para madeiras de folhosas (angiospermas - dicotiledôneas), registradas na ABNT, a classificação só é praticada na madeira destinada à exportação para os países desenvolvidos (ZENID, 1990).

No mercado nacional a madeira é vendida de forma não selecionada, a chamada "bica corrida", ou então segundo classificações genéricas como "primeira", "extra" etc., que freqüentemente são motivos de discordância entre compradores e vendedores. 
Como já mencionado anteriormente (ABPM, 1989a), a ausência de padronização é uma das queixas freqüentes do setor de construção civil, sendo, portanto, necessário que medidas efetivas sejam tomadas para resolução desse problema. Dentre estas, pode-se apontar: a revisão das normas e especificações disponíveis, sob a perspectiva do desempenho do material/produto no uso pretendido, divulgação das normas junto aos setores de produção, comércio e utilização de madeira serrada e treinamento de classificadores e de inspetores,

\subsubsection{Tratamento químico preservante}

Nas entrevistas realizadas foi perguntado se as empresas trabalhavam com madeira com algum tipo de tratamento químico preservante. No caso de resposta afirmativa foi solicitado informar qual era o tratamento empregado.

Tabela 25 - Tratamento químico preservante das peças de madeira serrada e beneficiada, nos distribuidores e construtoras.

\begin{tabular}{lrrrr}
\hline & \multicolumn{2}{c}{ Distribuidores } & \multicolumn{2}{c}{ Construtoras } \\
& $\mathrm{n}^{\circ}$ & $\%$ & $n^{\circ}$ & $\%$ \\
\hline Não & 27 & 64,3 & 18 & 82,0 \\
Sim & 9 & 21,4 & 3 & 14,0 \\
Não sabe & 6 & 14,3 & 1 & 4,0 \\
Total & 42 & 100,0 & 22 & 100,0 \\
\hline
\end{tabular}

Os resultados obtidos, apresentados na Tabela 25, revelam que o tratamento preservante não é aplicado, segundo $64,3 \%$ dos 
distribuidores e $82 \%$ das construtoras. Já $14,3 \%$ dos distribuidores e $4 \%$ das construtoras não sabem se a madeira comercializada/utilizada por eles recebeu algum tipo de tratamento. Dentre os que afirmaram trabalhar com madeira preservada $-21,4 \%$ dos distribuidores e $14 \%$ das construtoras, somente um indicou que comercializava madeira tratada sob pressão, em autoclave; os demais mencionaram tratamentos por imersão ou pincelamento, com produtos inseticidas, fungicidas ou com ambos.

Os dados apresentados são preocupantes, pois CHIMELO (1988) ${ }^{24}$ menciona que a presença de alburno foi o principal motivo de rejeição de peças destinadas a estrutura de cobertura de casas de conjuntos habitacionais populares e durante as visitas realizadas, neste estudo, foi observada a utilização de pinus sem tratamento preservante na contenção de solo (uso permanente).

LELIS \& LOPEZ (1993) constataram que os insetos foram os principais agentes deterioradores da madeira, detectados ao longo de 1966 inspeções realizadas pelo IPT, entre os anos de 1974 e 1992. Nessas inspeções, foi diagnosticada a necessidade de intervenção, para tratamento de controle, em 688 dos problemas apresentados ao IPT. Os custos envolvidos para a realização do controle são altos. Somente para os casos atendidos pelo IPT, o montante foi estimado em 1,3 milhão de dólares.

Face a essa situação, é necessário que as construtoras se conscientizem sobre o problema e que tomem as medidas adequadas, que vão desde a utilização de madeiras de cerne naturalmente durável (em peças sem alburno) ou madeiras não duráveis porém adequadamente tratadas, até a adoção de soluções arquitetônicas para minimizar a ação dos agentes deterioradores da madeira.

${ }^{24}$ CHIMELO, J.P. (1988) op. cit. 


\subsubsection{Secagem da madeira}

$\mathrm{Na}$ Tabela 26 são apresentados os resultados referentes à consulta sobre o emprego da secagem das peças de madeira comercializadas/utilizadas pelos distribuidores e construtoras.

Nessa Tabela observa-se que $91 \%$ dos distribuidores e $14 \%$ das construtoras disseram que empregam algum tipo de secagem das peças. Entre as 38 citações de distribuidores que comercializam peças de madeira nessa condição, foram feitas 21 citações de emprego da secagem ao ar e 27 em estufa.

Tabela 26 - Secagem das peças de madeira serrada e beneficiada, nos distribuidores e construtoras.

\begin{tabular}{lcccc}
\hline & \multicolumn{2}{c}{ Distribuidores } & \multicolumn{2}{c}{ Construtoras } \\
& $n^{\circ}$ & $\%$ & $n^{\circ}$ & $\%$ \\
\hline \multirow{2}{*}{ Não } & 3 & 7 & 19 & 86 \\
Sim & 38 & 91 & 3 & 14 \\
\multicolumn{1}{c}{ Ao ar } & $(21)$ & & 2 & \\
\multicolumn{1}{c}{ Em estufa } & $(27)$ & & 1 & \\
Não sabe & 1 & 2 & 0 & 100 \\
Total & 42 & 100 & 22 & \\
\hline
\end{tabular}

A discrepância das respostas fornecidas pelos distribuidores e construtoras pode ser explicada pela especialização das várias lojas visitadas, que trabalhavam com esquadrias e/ou assoalhos - usos em que a secagem deficiente resulta em problemas para os quais já há consciência, ainda que precária, por parte do consumidor - e da fase em que se 
encontravam as obra visitadas, onde predominavam os usos temporários, nos quais a secagem da madeira não é praticada.

Outra crítica que pode ser feita aos dados coletados é que não foi verificado se as madeiras estavam realmente secas. Não obstante isso, é importante salientar que já há consciência entre os distribuidores de que a madeira deve ser comercializada seca para determinados usos.

Tal fato é importante, pois são freqüentes as reclamaçōes de desempenho ruim da madeira, principalmente em assoalhos, em função do desconhecimento ou do menosprezo de sua característica de material higroscópico (WATAl, 1996) ${ }^{25}$.

\subsubsection{Forma de aquisição da madeira}

A forma de aquisição das peças de madeira pelos distribuidores e construtoras é apresentada na Tabela 27 (pág. 104), onde se observa que dentre os distribuidores, $7 \%$ têm produção própria, $81 \%$ adquirem de outros produtores e $12 \%$ obtêm a madeira de outros distribuidores.

Entre as construtoras a forma de aquisição predominante, em $68 \%$ das empresas entrevistadas, é através de distribuidores. Outros $23 \%$ adquirem diretamente de produtores. Somente uma empresa, ou seja $4 \%$ do total, tem produção própria.

Esses dados revelam a importância que os distribuidores ou revendas (denominação empregada pela ABPM, 1989a) desempenham no abastecimento de madeira serrada na construção civil habitacional na Cidade de São Paulo, devendo, portanto, ser considerados em qualquer ação de promoção do uso racional da madeira.

${ }^{25}$ WATAI, L.T. (IPT. Agrupamento de Propriedades Básicas da Madeira) Comunicação pessoal, 1996. 
Tabela 27 - Forma de aquisição das peças de madeira serrada e beneficiada, nos distribuidores e construtoras.

\begin{tabular}{lrrrr}
\hline & \multicolumn{2}{c}{ Distribuidores } & \multicolumn{2}{c}{ Construtoras } \\
& $\mathrm{n}^{\circ}$ & $\%$ & $\mathrm{n}^{0}$ & $\%$ \\
\hline Produção própria & 3 & 7 & 1 & 4 \\
$\begin{array}{l}\text { Produção de } \\
\text { terceiros }\end{array}$ & 34 & 81 & 5 & 23 \\
Distribuidor & 5 & 12 & 15 & 68 \\
Não sabe & 0 & & 1 & 4 \\
Total & 42 & 100 & 22 & 100 \\
\hline
\end{tabular}

\subsubsection{Critérios para a escolha das espécies de madeira}

Na Tabela 28 (pág. 105) são apresentados os critérios apontados pelos entrevistados, nas obras visitadas, para a escolha das espécies de madeira que estão sendo utilizadas.

Nessa Tabela pode ser observado que, em $50 \%$ dos casos, a madeira já vem especificada nos projetos e, em $18 \%$ das respostas, a tradição é o critério empregado na escolha das espécies de madeira. A disponibilidade no comércio, as informações prestadas pelos vendedores e 0 preço da madeira, perfazem $28 \%$ das respostas obtidas.

Se os distribuidores são importantes em qualquer ação para aprimorar o uso da madeira, conforme visto no item anterior, nas construtoras os projetistas são as peças chave a serem objetivadas nessas 
ações. Em posição secundária, porém importante, aparecem os responsáveis pela aquisição de materiais.

Tabela 28 - Critérios para a escolha das espécies de madeira que estão sendo utilizadas na obras visitadas.

\section{Critério}

Construtoras

$\mathrm{n}^{\circ}$

$\%$

Especificado em projeto

Tradição

Disponibilidade no comércio

Informações dos vendedores

2

9

Preço

1

5

Não sabe

1

5

Total

22

\subsubsection{Problemas do setor}

Nos distribuidores e construtoras visitados, foi solicitado que fossem apontados os principais problemas enfrentados no comércio/uso da madeira serrada e beneficiada.

Em função das respostas obtidas, os problemas relatados foram reunidos em três categorias: comercialização (compra e venda), qualidade e uso inadequado da madeira, conforme pode ser visto na Tabela 29. 
Tabela 29 - Problemas do setor segundo os distribuidores e construtoras.

\begin{tabular}{lcccc}
\hline & \multicolumn{2}{c}{ Distribuidores } & \multicolumn{2}{c}{ Construtoras } \\
& $\mathrm{n}^{0}$ & $\%$ & $\mathrm{n}^{\mathrm{0}}$ & $\%$ \\
\hline Sem problema & 12 & 29 & 7 & 32 \\
Com problemas & 30 & 71 & 15 & 68 \\
$\quad$ Qualidade & $(17)$ & & $(26)$ & \\
Comercialização & $(35)$ & & $(3)$ & \\
Uso inadequado & $(0)$ & & $(1)$ & \\
Total & 42 & 100 & 22 & 100 \\
\hline
\end{tabular}

$\mathrm{Na}$ Tabela 29 verifica-se que percentagens semelhantes de distribuidores e construtoras, $71 \%$ e $68 \%$, respectivamente, apontaram a existência de problemas no setor.

Nos distribuidores os problemas relacionados com a comercialização receberam 35 citações, enquanto que nas construtoras ocorreram apenas três citações. Tais problemas estão relacionados na Tabela 30 (pág. 108), onde pode ser visto que, entre os distribuidores, os maiores problemas citados são: preço alto das madeiras, frete, escassez de madeiras e pressão ambiental. Num patamar inferior foram citados os seguintes problemas: impostos, concorrência das grandes empresas, fraudes, competição com a exportação, sazonalidade da produção, necessidade de vários fornecedores e a falta de conhecimento sobre a madeira por parte dos clientes.

Entre as construtoras, foram citados apenas o preço do frete e da madeira como problemas comerciais. 
Confrontando esses resultados com aqueles apresentados pela ABPM (1989a) verifica-se uma concordância quanto aos principais problemas relatados, ou seja, alto custo da madeira e os problemas relacionados com o frete. Para a ABPM (1989a), são também importantes os problemas relacionados com a falta de fornecedores idôneos e a irregularidade das entregas (provavelmente associado à sazonalidade de produção, aos problemas de transporte e mesmo à idoneidade dos fornecedores que assumem compromissos acima de sua capacidade de produção).

Chamam a atenção as citações referentes à escassez de madeira, paradoxalmente num País detentor da maior reserva mundial de florestas tropicais. A explicação para isto está na concentração do mercado em poucas espécies de madeira, herança da grande abundância de pinho-doparaná e peroba-rosa.

Outro aspecto importante, já mencionado na Introdução deste trabalho, diz respeito às questões ambientais que já se fazem sentir, embora discretamente, no comércio doméstico brasileiro de madeira serrada. Tal fato, poderá se constituir em importante motivação para exploraçōes ambientalmente adequadas, tanto de florestas nativas como plantadas.

Na Tabela 31 (pág. 109) são apresentados os problemas de qualidade apontados pelos distribuidores e construtoras. Entre os distribuidores os problemas mais freqüentemente apontados são o teor de umidade e desbitolamento das peças. A estes somam-se os problemas gerais de qualidade e a mistura de espécies.

Já entre as construtoras os problemas mais apontados referem-se à presença de defeitos naturais e de processamento (mal serrada). A mistura de espécies, a ausência de padronização e a umidade das peças são também problemas apontados pelas construtoras. 
Tabela 30 - Problemas de comercialização relatados pelos distribuidores e construtoras.

\begin{tabular}{lrrrr}
\hline \multicolumn{1}{c}{ Problema } & \multicolumn{3}{c}{ Distribuidores } & \multicolumn{2}{c}{ Construtoras } \\
& $\mathrm{n}^{\mathrm{o}}$ & $\%$ & $\mathrm{n}^{\mathrm{o}}$ & $\%$ \\
\hline Preço alto & 7 & 20 & 2 & 67 \\
Frete & 7 & 20 & 1 & 33 \\
Escassez de madeira & 6 & 17 & 0 & 0 \\
Pressão ambiental & 4 & 11 & 0 & 0 \\
Impostos & 3 & 9 & 0 & 0 \\
Concorrência das grandes empresas & 2 & 6 & 0 & 0 \\
Fraudes & 2 & 6 & 0 & 0 \\
Competição com a exportação & 1 & 3 & 0 & 0 \\
Sazonalidade da produção & 1 & 3 & 0 & 0 \\
Necessidade de vários fornecedores & 1 & 3 & 0 & 0 \\
Cliente desconhece a madeira & 1 & 3 & 0 & 0 \\
Total & 35 & 100 & 3 & 100 \\
\hline
\end{tabular}

Esses problemas não diferem daqueles apresentados pela ABPM (1989a), exceto que os problemas relativos ao teor de umidade das peças de madeira foram apresentados por distribuidores e construtoras, o que de certa forma contradiz as informações apresentadas na Tabela 26 (pág.102).

Finalmente, entre as construtoras (vide Tabela 29, pág. 106), foi citado o desperdício de madeira que há nas obras, em razão da mãode-obra despreparada e das dimensões inadequadas das peças. 
Os problemas levantados são alimentadores do preconceito relativo à madeira como material de construção, o qual, por sua vez, não estimula os setores produtivos e de engenharia a buscar 0 aprimoramento técnico na produção e na utilização da madeira, o que acaba refletindo no pouco valor, econômico e ambiental, que se dá às nossas florestas (UNIDO, 1983; KEENAN \& TEJADA, 1984; PEREZ \& KAMAZOE, 1988; FREITAS, 1988 e WOLFE,1991).

Tabela 31 - Problemas de qualidade relatados pelos distribuidores e construtoras.

Problema

Distribuidores Construtoras

$\mathrm{n}^{\circ} \quad \% \quad \mathrm{n}^{\mathrm{0}} \quad \%$

\begin{tabular}{lrrrr} 
Qualidade em geral & 5 & 29 & 0 & 0 \\
Desbitolamento (mal serrada) & 4 & 23 & 5 & 19 \\
Umidade & 7 & 41 & 3 & 11 \\
Mistura de espécies & 1 & 6 & 4 & 15 \\
Defeitos nas peças & 0 & 0 & 10 & 39 \\
Ausência de padronização & 0 & 0 & 3 & 11 \\
Falta de uniformidade & 0 & 0 & 1 & 4 \\
Total & 17 & 100 & 26 & 100 \\
\hline
\end{tabular}

5.3. Agrupamento das madeiras identificadas de acordo com o uso final na construção civil habitacional

As espécies ou grupos de espécies de madeiras identificadas neste trabalho (vide Tabela 14, pág. 68), foram reunidas em 
grupos de usos finais na construção civil habitacional segundo as informações de uso fornecidas pelos entrevistados (distribuidores e construtoras) e de acordo com o critério de classificação proposto neste trabalho.

Além das 57 espécies de madeira identificadas no levantamento realizado, foram incluídas outras 12 espécies, listadas na Tabela 32, encontradas pelo IPT (IPT, 1993) em levantamento realizado em estruturas de cobertura das casas de dois conjuntos habitacionais populares (vide Tabela 12, pág. 36).

Tabela 32 - Espécies de madeira identificadas pelo IPT, em estruturas de cobertura de casas, e que não foram detectadas neste trabalho.

\begin{tabular}{ll}
\hline Nome Comercial & Nome Científico \\
\hline abiurana & Pouteria sp, Sapotaceae \\
angelim-vermelho & Dinizia excelsa, Leguminosae \\
araracanga & Aspidosperma sp, Apocynaceae \\
copaiba & Copaifera sp, Leguminosae \\
guariúba & Clarisia racemosa, Moraceae \\
jarana & Holopyxidium jarana, Lecythidaceae \\
pau-jacaré & Laetia procera, Flacourtiaceae \\
roxinho & Peltogyne sp, Leguminosae \\
tanibuca & Terminalia sp, Combretaceae \\
taxi & Tachigalia sp, Leguminosae \\
timborana & Piptadenia suaveolens, Leguminosae \\
uxi & Endopleura uchi, Humiriaceae \\
\hline
\end{tabular}




\subsubsection{Agrupamento de acordo com as informações fornecidas pelos entrevistados}

Os usos finais apontados pelos distribuidores e construtoras foram reunidos em grupos de usos, sem a realização de qualquer tipo de análise sobre a adequação da informação prestada. Portanto, os agrupamentos apresentados a seguir, nas Tabelas 33 (pág. 112) a 38 (pág. 117), devem ser encarados como meramente informativos.

Ao se analisar os agrupamentos das espécies de madeira identificadas, realizados com base nas informações de uso prestadas pelos entrevistados, verifica-se que os grupos com características estruturais reúnem a maior quantidade de espécies de madeira (leve externo e interno estrutural, com 31 madeiras, e pesado interno, com 29 madeiras). Nesses dois agrupamentos verifica-se, também, que as indicações foram feitas predominantemente pelas construtoras.

Num patamar inferior, estão os agrupamentos de uso onde as características de estabilidade dimensional e o aspecto decorativo são relevantes (leve em esquadria e assoalhos domésticos, com 20 madeiras cada um; e leve interna decorativa, com 19). O quadro fecha-se com o agrupamento leve interno de utilidade geral, onde foram reunidas 12 madeiras.

Nesses quatro agrupamentos de uso verifica-se que as indicações foram feitas predominantemente pelos distribuidores.

Tais observações podem ser explicadas pela fase em que se encontravam as obras das construtoras visitadas, onde predominavam os usos estruturais, enquanto que, entre os distribuidores visitados, várias lojas eram especializadas em assoalhos e esquadrias. 
Tabela 33 - Agrupamento por uso final, segundo informações dos entrevistados: PESADA INTERNA.

\begin{tabular}{|c|c|c|}
\hline Nome Comercial & Distribuidor & Construtora \\
\hline abiurana & & + \\
\hline angelim-pedra & & + \\
\hline angelim-vermelho & & + \\
\hline angico-preto & + & + \\
\hline angico-vermelho & + & + \\
\hline araracanga & & + \\
\hline bacuri & & + \\
\hline bacuri-de-anta & & + \\
\hline cambará & & + \\
\hline canafístula & + & + \\
\hline copaíba & & + \\
\hline cumaru & + & \\
\hline cupiúba & + & \\
\hline garapa & + & \\
\hline guariúba & & + \\
\hline ipê & + & \\
\hline itaúba & + & \\
\hline jarana & & + \\
\hline jatobá & + & \\
\hline maçaranduba & + & \\
\hline pau-jacaré & & + \\
\hline peroba-mica & + & \\
\hline peroba-rosa & + & \\
\hline piquiá & + & \\
\hline roxinho & & + \\
\hline tanibuca & & + \\
\hline taxi & & + \\
\hline timborana & & + \\
\hline uxi & & + \\
\hline
\end{tabular}


Tabela 34 - Agrupamento por uso final, segundo informações dos entrevistados: LEVE, EM ESQUADRIA.

\begin{tabular}{lcc}
\hline Nome Comercial & Distribuidor & Construtora \\
\hline angelim-pedra & & \\
cabreúva-vermelha & + & + \\
cedrinho & + & \\
cedro & + & + \\
cerejeira & + & \\
cumaru & + & \\
freijó & + & + \\
garapa & + & \\
imbuia & + & \\
ipê & + & \\
itaúba & + & \\
jacareúba & + & \\
jatobá & + & \\
louro-canela & + & \\
louro-vermelho & + & \\
marinheiro & + & + \\
mogno & + & \\
peroba-mica & + & \\
peroba-rosa & & \\
vinhático & & \\
\hline
\end{tabular}

Obs. Vide Tabelas 14 (pág. 68) e 32 (pág. 110), para se obter os nomes científicos. 
Tabela 35 - Agrupamento por uso final, segundo informações dos entrevistados: LEVE EXTERNA E INTERNA ESTRUTURAL.

\begin{tabular}{|c|c|c|}
\hline Nome Comercial & Distribuidor & Construtora \\
\hline amescla & & + \\
\hline angelim-pedra & & + \\
\hline angico-preto & & + \\
\hline angico-vermelho & & + \\
\hline bacuri-de-anta & & + \\
\hline cambará & + & + \\
\hline castanheira & & + \\
\hline cedrinho & + & + \\
\hline cedrorana & & + \\
\hline cuningâmia & & + \\
\hline cupiúba & & + \\
\hline cupressus & + & + \\
\hline eucalipto & + & + \\
\hline fava-orelha-de-macaco & & + \\
\hline faveira & & + \\
\hline faveira-amargosa & & + \\
\hline freijó & & + \\
\hline glícia & & + \\
\hline goiabão & & + \\
\hline grevílea & + & \\
\hline guatambu-peroba & & + \\
\hline jatobá & & + \\
\hline louro-canela & & + \\
\hline muiracatiara & & + \\
\hline peroba-mica & & + \\
\hline peroba-rosa & & + \\
\hline pinho-do-paraná & + & + \\
\hline pinus & + & + \\
\hline piquiarana & + & \\
\hline quaruba & & + \\
\hline rosadinho & & + \\
\hline
\end{tabular}

Obs. Vide Tabelas 14 (pág. 68) e 32 (pág. 110), para se obter os nomes científicos. 
Tabela 36 - Agrupamento por uso final, segundo informações dos entrevistados: LEVE INTERNA DECORATIVA.

\begin{tabular}{lcc}
\hline Nome Comercial & Distribuidor & Construtora \\
\hline angelim-pedra & + & \\
cambará & + & \\
cedrinho & + & \\
cedro & + & \\
cerejeira & + \\
cumaru & + \\
faveira-amargosa & + \\
freijó & + \\
imbuia & + \\
ipê & + \\
jutaí-cica & + \\
marupá & + \\
mogno & + \\
pau-marfim & + \\
pau-mulato & + \\
peroba-rosa & + \\
pinho-do-paraná & + \\
sucupira & + \\
tatajuba & + \\
\hline
\end{tabular}

Obs. Vide Tabelas 14 (pág. 68) e 32 (pág. 110), para se obter os nomes científicos. 
Tabela 37 - Agrupamento por uso final, segundo informações dos entrevistados: LEVE INTERNA DE UTILIDADE GERAL.

\begin{tabular}{lcc}
\hline Nome Comercial & Distribuidor & Construtora \\
\hline angelim-pedra & + & \\
cambará & + & \\
cedrinho & + & \\
cedrorana & + & \\
louro-canela & + & \\
marupá & + & \\
pau-mulato & + & \\
peroba-mica & & + \\
peroba-rosa & + & \\
pinho-do-paraná & + & \\
pinus & + & \\
quaruba & + \\
\hline
\end{tabular}

Obs. Vide Tabelas 14 (pág. 68) e 32 (pág. 110), para se obter os nomes científicos. 
Tabela 38 - Agrupamento por uso final, segundo informações dos entrevistados: ASSOALHOS DOMÉSTICOS.

\begin{tabular}{lcc}
\hline Nome Comercial & Distribuidor & Construtora \\
\hline angelim-pedra & + & \\
angico-preto & + & \\
cabreúva-vermelha & + & \\
cumaru & + & \\
garapa & + & + \\
goiabão & + \\
imbuia & + \\
ipê & + \\
jatobá & + \\
jutaí-cica & + \\
macacaúba & + \\
mogno & + \\
pau-amarelo & + \\
pau-marfim & + \\
pau-mulato & + \\
peroba-mica & + \\
peroba-rosa & + \\
sucupira & + \\
tatajuba & + \\
tauari & + \\
\hline
\end{tabular}

Obs. Vide Tabelas 14 (pág. 68) e 32 (pág. 110), para se obter os nomes científicos. 
A grande variabilidade encontrada no agrupamento "leve externa e interna estrutural" se deve, em grande parte, às 15 espécies de madeira que foram confundidas com o cedrinho (vide Tabela 20, pág. 86)).

Também merece destaque a indicação de algumas espécies tanto para o agrupamento "leve interno decorativo", como para o "leve interno de utilidade geral", que se distinguem, basicamente, pelo aspecto decorativo da madeira.

Essa característica, que depende de quem a avalia, está sujeita às mudanças de tendências na decoração de ambientes. Atualmente a procura é maior por madeiras claras.

\subsubsection{Agrupamento de acordo com o critério de classificação proposto}

$\mathrm{Na}$ pesquisa para obtenção das propriedades necessárias para classificar as espécies de madeira de acordo com os grupos de uso final, foram constatadas, na bibliografia consultada, as deficiências de informações relatadas a seguir:

- espécies de madeira com pouca ou nenhuma informação: angelim-pedra (Hymenolobium elatum e $H$. heterocarpum), araracanga, cambará (Qualea homosepala), faveira, jutaí-cica e peroba-mica;

- espécies de madeira sem informaçōes sobre trabalhabilidade: angico-preto, angico-vermelho, cabreúva-vermelha, cambará (Ruizterania albiflora), canafistula, cuningâmia, cupressus, grevílea, guatambu-peroba, pau-mulato e vinhático;

- espécies de madeira sem informações sobre fixação mecânica: angico-preto, angico-vermelho, bacuri-de-anta, cabreúva-vermelha, cambará (Ruizterania albiflora), canafístula, castanheira, cerejeira, 
cuningâmia, cupressus, eucalipto, faveira-amargosa, garapa, glícia, grevílea, guatambu-peroba, itaúba, muiracatiara, pau-jacaré, paumarfim, pau-mulato e vinhático;

- espécies de madeira sem informações sobre durabilidade natural e tratabilidade:

abiurana, faveira-amargosa, glícia, grevílea, pau-mulato e taxi;

- espécies de madeira com durabilidade natural baixa e sem informações sobre tratabilidade:

bacuri-de-anta, cambará, cerejeira, cuningâmia, cupressus, pauamarelo e rosadinho.

Essas listas de espécies de madeira com informações total ou parcialmente incompletas sobre suas características tecnológicas, poderão servir de orientação para estudos de caracterização, visto que algumas das espécies de madeira citadas já estāo sendo comercializadas de forma significativa, por exemplo: angelim-pedra - Hymenolobium elatum e $H$. heterocarpum, cambará - Qualea homosepala, jutaí-cica - Martiodendron cf. elatum e peroba-mica - Aspidosperma cf. macrocarpon.

Nos agrupamentos apresentados a seguir, estão relacionadas as madeiras que atenderam a todos os requisitos de classificação e aquelas que cumpriram parcialmente, por ausência de dados ou porque os mesmos estavam abaixo dos limites estabelecidos. Tal atitude foi tomada em relação às propriedades de trabalhabilidade, fixação mecânica, durabilidade natural/tratabilidade e estabilidade dimensional, cuja deficiência pode ser minimizada com o uso de técnicas apropriadas.

$\mathrm{Na}$ Tabela 39 (pág. 121) são apresentados os resultados do agrupamento das espécies de madeira para "construção civil pesada interna". Nessa Tabela, verifica-se que foram classificadas 35 espécies de madeira, das quais 11 satisfizeram todas as exigências do grupo. As demais espécies têm 
restrições com relação à fixação mecânica (13 espécies) e/ou durabilidade natural/tratabilidade (11 espécies).

Em relação aos resultados apresentados na Tabela 33 (agrupamento com base nas informações dos entrevistados, pág. 112) verificase que sete espécies não são citadas na Tabela 39 (pág. 121). As razões são as seguintes: ausência de informações sobre as propriedades mecânicas da madeira (araracanga e peroba-mica) e valores das mesmas abaixo dos limites estabelecidos na classificação (cambará, canafistula, copaíba, guariúba e paujacaré). De outro lado, 15 espécies constantes na Tabela 39 não são mencionadas na Tabela 33. Isto se deve, em parte, a várias dessas espécies serem decorativas e, portanto, utilizadas em usos mais nobres (cabreúvavermelha, muiracatiara, p. ex.) ou por serem espécies desconhecidas e com baixa oferta (fava-orelha-de-macaco, piquiarana, p.ex.).

$\mathrm{Na}$ Tabela 40 (pág. 122) são apresentadas as 17 espécies de madeira classificadas no grupo "construção civil leve, em esquadria". Apenas quatro espécies possuem todos os requisitos estabelecidos. As demais têm problemas relativos a ausência de informação e/ou deficiência em relação às seguintes propriedades: fixação mecânica, estabilidade dimensional e durabilidade natural/tratabilidade.

Dentre as madeiras citadas na Tabela 34 (usos indicados pelos entrevistados, pág. 113) oito não foram incluídas na Tabela 40, em razão de: densidade de massa, a $15 \%$ do teor de umidade, acima do máximo estabelecido para o grupo (cumaru, ipê, jatobá etc.); requisitos abaixo do estabelecido (jacareúba) e propriedades tecnológicas não disponíveis (perobamica). A questão referente às espécies com densidade de massa acima do especificado será discutida mais adiante. 
Tabela 39 - Agrupamento por uso final, de acordo com o critério de classificação: PESADA INTERNA.

Referência: peroba-rosa

\begin{tabular}{|c|c|c|c|}
\hline Nome Comercial & Observação & Nome Comercial & Observação \\
\hline abiurana & 2 e 3 & jarana & 1 \\
\hline angelim-pedra & 1 & jatobá & 2 \\
\hline angelim-vermelho & 2 & macacaúba & 2 \\
\hline angico-preto & 2 & maçaranduba & 2 \\
\hline angico-vermelho & 2 & muiracatiara & 2 e 3 \\
\hline bacuri & 2 & pau-amarelo & 3 \\
\hline bacuri-de-anta & 2 e 3 & pau-marfim & 2 e 3 \\
\hline cabreúva-vermelha & 2 & pau-mulato & 2 e 3 \\
\hline cumaru & 1 & piquiarana & 1 \\
\hline cupiúba & 2 & piquiá & 1 \\
\hline $\begin{array}{l}\text { eucalipto(E. } \\
\text { tereticornis) }\end{array}$ & 2 e 3 & rosadinho & 3 \\
\hline $\begin{array}{l}\text { fava-orelha-de- } \\
\text { macaco }\end{array}$ & 1 & roxinho & 1 \\
\hline faveira-amargosa & 2 e 3 & sucupira & 2 \\
\hline garapa & 2 & tanibuca & 1 \\
\hline goiabão & 2 e 3 & tatajuba & 2 \\
\hline guatambu-peroba & 2 & timborana & 1 \\
\hline ipê & 1 & uxi & 3 \\
\hline itaúba & 1 & & \\
\hline
\end{tabular}

Obs. Ver Tabelas 14 (pág. 68) e 32 (pág. 110), para obter os nomes cientificos. 1. Atendeu a todos os critérios de classificação.

2. Fixação mecânica: deficiente ou sem informação.

3. Durabilidade natural e/ou tratabilidade: deficiente ou sem informação. 
Tabela 40 - Agrupamento por uso final, de acordo com o critério de classificação: LEVE, EM ESQUADRIA.

Referência: pinho-do-paraná

\begin{tabular}{lc||lc}
\hline \multicolumn{1}{c||}{ Nome Comercial } & Observação & Nome Comercial & Observação \\
\hline angelim-pedra & 1 & louro-canela & 3 e 4 \\
bacuri & 2 e 3 & louro-vermelho & 3 \\
castanheira & 2 e 3 & marinheiro & 3 \\
cedrinho & 3 & mogno & 1 \\
cedro & 1 & pau-amarelo & 3 e 4 \\
cerejeira & 2,3 e 4 & pau-marfim & 2,3 e 4 \\
freijó & 1 & tauari & 2 e 3 \\
garapa & 2 e 3 & taxi & 4 \\
imbuia & 3 & & \\
\hline
\end{tabular}

Obs. Ver Tabelas 14 (pág. 68) e 32 (pág. 110), para obter os nomes científicos.

1. Atendeu a todos os critérios de classificação.

2. Fixação mecânica: deficiente ou sem informação.

3. Estabilidade dimensional: deficiente.

4. Durabilidade natural e/ou tratabilidade: deficiente ou sem informação.

O agrupamento das espécies de madeira para "construção civil leve externa e interna estrutural" é apresentado na Tabela 41 (pág. 124), onde se observa que 29 espécies foram reunidas.

Desse total somente nove espécies de madeira têm todos os requisitos necessários para se classificar, segundo a metodologia proposta, 
nesse grupo de usos. As demais espécies não atenderam e/ou não havia informações disponiveis na bibliografia consultada, no que se refere às seguintes características: fixação mecânica e durabilidade natural/tratabilidade.

Ao se comparar os resultados da Tabela 41 com aqueles da Tabela 35 (pág. 114) e vice-versa, (agrupamento com base nos usos reportados pelos entrevistados) verifica-se que, coincidentemente, 17 espécies não constam em ambas as Tabelas.

A densidade de massa, a $15 \%$ de teor de umidade, acima do limite superior estabelecido para o grupo, foi um dos fatores de exclusão de algumas espécies da Tabela 35 na Tabela 41 (angico-preto, cupiúba, jatobá etc.). Conceitualmente o critério de classificação proposto visa aproveitar aquelas madeiras com menor resistência mecânica em um uso compatível, estruturalmente mais leve, em que o pinho-do-paraná apresenta excelente desempenho. No entanto, obviamente, isso não deve ser entendido como um fator restritivo ao uso de madeiras mais densas nesse uso.

Por outro lado, outras madeiras não foram incluídas por apresentarem propriedades mecânicas abaixo dos limites estabelecidos para o grupo (pinus, cuningâmia, cedrorana, grevílea etc.). Nesses casos, estas madeiras só deveriam ser admitidas em partes não estruturais de andaimes ou em outros usos em que as propriedades mecânicas requeridas sejam compativeis com as do material.

Nas Tabelas 33 (pág. 112), 35 (pág. 114), 39 (pág. 121) e 41 (pág. 124), está relacionado o maior número de espécies por grupos de uso final. Esses usos se caracterizam por serem estruturais e requererem propriedades mecânicas. Esse fato deve ser considerado como um indício de que a técnica de agrupamento é mais factível de sucesso nesses grupos de usos estruturais, o que está de acordo com o proposto por KEATING (1983) e HANSOM (1983). 
Tabela 41 - Agrupamento por uso final, de acordo com o critério de classificação: LEVE EXTERNA E INTERNA ESTRUTURAL. Referência: pinho-do-paraná

\begin{tabular}{|c|c|c|c|}
\hline Nome Comercial & Observação & Nome Comercial & Observação \\
\hline angelim-pedra & 1 & louro-canela & 3 \\
\hline bacuri & 2 & louro-vermelho & 1 \\
\hline bacuri-de-anta & 2 e 3 & marinheiro & 1 \\
\hline cambará & 1 & mogno & 1 \\
\hline canafístula & 2 & pau-amarelo & 3 \\
\hline castanheira & 2 & pau-jacaré & 2 \\
\hline cedrinho & 1 & pau-mulato & 2 e 3 \\
\hline cerejeira & 2 e 3 & peroba-rosa & 1 \\
\hline copaíba & 3 & piquiarana & 1 \\
\hline eucalipto ( $E$. grandis & & quaruba & 3 \\
\hline e E. saligna) & 2 e 3 & & \\
\hline freijó & 1 & rosadinho & 3 \\
\hline garapa & 2 & tatajuba & 2 \\
\hline glícia & 2 e 3 & tauari & 2 \\
\hline guatambu-peroba & 2 & $\operatorname{taxi}$ & 3 \\
\hline jacareúba & 3 & & \\
\hline
\end{tabular}

Obs. Ver Tabelas 14 (pág. 68) e 32 (pág. 110), para obter os nomes científicos.

1. Atendeu a todos os critérios de classificação.

2. Fixação mecânica: deficiente ou sem informação.

3. Durabilidade natural e/ou tratabilidade: deficiente ou sem informação. 
As 22 espécies de madeiras classificadas para o grupo "construção civil leve interna decorativa" são apresentadas na Tabela 42 (pág. 126). Desse total, somente sete espécies atenderam a todos os requisitos de classificação. Nas demais ocorreu a falta de informação ou deficiência nas seguintes características: fixação mecânica, estabilidade dimensional, trabalhabilidade e durabilidade natural/tratabilidade.

Dentre as 19 espécies de madeira relacionadas na Tabela 36 (uso indicado pelos entrevistados, pág. 115), sete não foram incluídas na Tabela 42, principalmente por não terem sido consideradas decorativas (marupá, cedrinho, pinho-do-paraná etc.).

Na Tabela 43 (pág. 127) estão listadas as 16 espécies de madeira classificadas no grupo "construção civil leve interna de utilidade geral". Somente três espécies possuem todas as características exigidas para classificação. Para as demais há falta de informação ou deficiência nas seguintes características: fixação mecânica, estabilidade dimensional, trabalhabilidade e durabilidade natural/tratabilidade.

Somente três das espécies listadas na Tabela 37 (usos fornecidos pelos entrevistados, pág. 116) não atenderam os requisitos de classificação: angelim-pedra e pau-mulato (densidade de massa alta), e peroba-mica (sem informações).

Finalmente na Tabela 44 (pág. 128) são apresentadas as 21 espécies de madeira que foram classificadas no grupo "construção civil assoalhos domésticos". Dentre as madeiras classificadas somente uma, o ipê, atendeu a todas exigências requeridas para este grupo. As demais madeiras tiveram principalmente problemas referentes à fixação mecânica (deficiente ou sem informação) e à estabilidade dimensional deficiente. 
Tabela 42 - Agrupamento por uso final, de acordo com o critério de classificação: LEVE INTERNA DECORATIVA.

Referência: imbuia (3)

\begin{tabular}{llc||llc}
\hline Nome Comercial & Cor * & Obs. & Nome Comercial & Cor * & Obs. \\
\hline angelim-pedra & acast & 1 & macacaúba & acast & 2 \\
bacuri & acast & 2 e 3 & marinheiro & ros/aver & 3 \\
cedro & ros/aver & 1 & mogno & ros/aver & 1 \\
cerejeira & acast & 2 e 5 & muiracatiara & ros/aver & 2 e 5 \\
cumaru & acast. & 3 & pau-amarelo & amar & 3 e 5 \\
freijó & acast & 1 & pau-marfim & esbr & $2,3,5$ \\
grevílea & ros/aver & 3 & peroba-rosa & ros/aver & 1 \\
guariúba & amar & 1 & roxinho & arrox & 3 \\
ipê & acast & 1 & sucupira & acast & 2 e 3 \\
jatobá & acast & 2 e 3 & tatajuba & amar & 2 e 3 \\
louro-vermelho & ros/aver & 3 & vinhático & amar & 2 e 4 \\
\hline
\end{tabular}

Obs. Ver Tabelas 14 (pág. 68) e 32 (pág. 110), para obter os nomes científicos.

* Cor: acast: acastanhada, amar: amarelada, arrox: arroxeada, esbr: esbranquiçada, ros/aver: rosada ou avermelhada.

1. Atendeu a todos os critérios de classificação.

2. Fixação mecânica: deficiente ou sem informação.

3. Estabilidade dimensional: deficiente.

4. Trabalhabilidade: deficiente ou sem informação.

5. Durabilidade natural e/ou tratabilidade: deficiente ou sem informação. 
Tabela 43 - Agrupamento por uso final, de acordo com o critério de classificação: LEVE INTERNA DE UTILIDADE GERAL. Referência: pinho-do-paraná

\begin{tabular}{lc||lc}
\hline \multicolumn{1}{c||}{ Nome Comercial } & Observação & Nome Comercial & Observação \\
\hline amescla & 1 & faveira & 2,4 \\
cambará & $2,3,4$ e 5 & jacareúba & 3 \\
cedrinho & 3 & louro-canela & 3 e 5 \\
cedrorana & 3 & marupá & 1 \\
copaíba & 3 e 5 & pinus & 1 \\
cuningâmia & $2,3,4$ e 5 & quaruba & 3 e 5 \\
cupressus & 2,4 e 5 & tauari & 2,3 \\
eucalipto (E. grandis; & & taxi & 5 \\
E. saligna) & 2,3 e 5 & & \\
\hline
\end{tabular}

Obs. Ver Tabelas 14 (pág. 68) e 32 (pág. 110), para obter os nomes científicos.

1. Atendeu a todos os critérios de classificação.

2. Fixação mecânica: deficiente ou sem informação.

3. Estabilidade dimensional: deficiente.

4. Trabalhabilidade: deficiente ou sem informação.

5. Durabilidade natural e/ou tratabilidade: deficiente ou sem informação. 
Tabela 44 - Agrupamento por uso final, de acordo com o critério de classificação: ASSOALHOS DOMÉSTICOS.

Referência: peroba-rosa

\begin{tabular}{lc||lc}
\hline \multicolumn{1}{c||}{ Nome Comercial } & Observação & Nome Comercial & Observação \\
\hline angico-preto & 2,3 e 5 & muiracatiara & 2 e 4 \\
angico-vermelho & 2,3 e 5 & pau-amarelo & 3,4 e 6 \\
bacuri & 2 e 3 & pau-marfim & 2,3 e 4 \\
cabreúva-vermelha & 2 e 5 & pau-mulato & 2,3 e 4 \\
cumaru & 3 & roxinho & 3 \\
garapa & 2 e 3 & sucupira & 2 e 3 \\
goiabão & $2,3,4$ e 6 & tanibuca & 3 \\
ipê & 1 & tatajuba & 2 e 3 \\
jatobá & 2 e 3 & timborana & 3 e 6 \\
macacaúba & 2 e 6 & uxi & 3,4 e 6 \\
maçaranduba & 2 e 3 & & \\
\hline
\end{tabular}

Obs. Ver Tabelas 14 (pág. 68) e 32 (pág. 110), para obter os nomes científicos.

1. Atendeu a todos os critérios de classificação.

2. Fixação mecânica: deficiente ou sem informação.

3. Estabilidade dimensional: deficiente.

4. Durabilidade natural e/ou tratabilidade: deficiente ou sem informação.

5. Trabalhabilidade: deficiente ou sem informação.

6. Choque: sem informação. 
O uso de espécies com problemas de estabilidade dimensional para confecção de assoalhos, ao lado de outras deficiências como: teor de umidade médio das peças acima da umidade de equilíbrio, acentuada variação do teor de umidade entre as peças, proporção alta entre largura e espessura das peças e instalação ruim (contra-piso úmido, fixação errada etc.); resulta em desempenho abaixo do desejável (empenamentos, frestas entre peças, rachamentos etc.) e, portanto, insatisfação do usuário final.

Comparando-se os resultados apresentados na Tabela 38 (uso indicado pelos entrevistados, pág. 117)) com os da Tabela 44, verifica-se que seis espécies de madeira não foram classificadas para assoalhos domésticos. Isto se deve à deficiência nas propriedades mecânicas (angelimpedra, imbuia, mogno e tauari) e ausência de informações tecnológicas (jutaícica e peroba-mica). 


\section{CONCLUSÕES}

Foram identificadas 57 espécies de madeira (espécies ou grupos de espécies de difícil distinção na prática) sendo utilizadas, na forma de madeira serrada/beneficiada, na construção civil habitacional na Cidade de São Paulo.

Das espécies identificadas, 29 são tipicamente amazônicas, 16 têm ampla dispersão no Brasil e países limítrofes, sete são não amazônicas e cinco são originárias de reflorestamentos.

Dentre as madeiras de reflorestamento, a cuningâmia, cupressus e grevílea, não haviam sido citadas nos levantamentos anteriores consultados.

Embora a heterogeneidade das florestas tropicais, em especial a Amazônica, se reflita na quantidade de espécies encontradas, cerca de 15 espécies representam $80 \%$ do total das amostras coletadas, o que indica que o comércio se abastece com um número relativamente pequeno de espécies. Dentre estas, madeiras já tradicionais, como: pinho-do-paraná, peroba-rosa, ipê e jatobá, ainda desempenham um papel importante no abastecimento do mercado voltado à construção civil.

Dentre as madeiras de reflorestamento, somente o pinus é utilizado significativamente. Já entre as amazônicas, o cedrinho se consolida como a substituta do pinho-do-paraná, sendo amplamente utilizada na construção civil leve externa (usos temporários, principalmente) e interna estrutural. 
Tais constatações mostram como o setor ainda é refratário à utilização de novas espécies. No entanto, há indícios de mudança.

Ao se analisar o nome comercial dado pelos entrevistados em relação àqueles obtidos com a identificação botânica feita em laboratório, verificou-se que a maior quantidade de erros ocorreu entre as construtoras. 0 cedrinho foi responsável por $43 \%$ dos erros, tendo sido aplicado esse nome a 15 diferentes espécies de madeira (amazônicas e de reflorestamento), que em comum tinham, além desse nome, o fim a que eram destinadas: uso temporário nas obras.

O lado positivo dessa verificação é a constatação da aplicação prática do conceito de agrupamento de espécies por uso final (várias espécies sendo aplicadas num determinado uso) e a aceitaçăo, portanto, de outras espécies de madeira não tradicionais.

Porém, a forma como este processo está se desenvolvendo, baseado na escolha das espécies pela tentativa-e-erro e sem, pelo menos aparentemente, o conhecimento do consumidor, é inapropriada e poderá aumentar o preconceito em relação a madeira como material de construção.

A constatação de erros de identificação das madeiras pelos distribuidores e, principalmente, pelas construtoras, ressalta a necessidade de adoção, por parte desses agentes, de uma técnica de identificação mais adequada, como a baseada na estrutura anatômica do lenho.

Outra medida importante que pode minimizar os problemas de comercialização/utilização gerados pelo uso de nomes comerciais inadequados, é a adoção de uma padronização da nomenclatura comercial das madeiras. Para tal, o documento elaborado pelo antigo IBDF (IBDF, 1987), devidamente atualizado, será de grande valia. 
A Região Sul é ainda um importante centro supridor de madeira serrada e beneficiada, oriunda da própria região ou importada de outras, para construção civil na Cidade de São Paulo. Como suas fontes de suprimento são restritas, a tendência - mantidas as condições atuais de pouca utilização da madeira gerada nos reflorestamento (eucalipto, principalmente) é de que a Amazônia aumente ainda mais sua participação nesse mercado.

Com relação às dimensões das peças foi constatado que há uma variedade de bitolas (largura X espessura) ditas "de mercado", sendo que vários distribuidores têm capacidade para atender "sob medida". Há confusão ao se relacionar o nome das peças com suas respectivas bitolas.

No que diz respeito à classificação das peças em classes de qualidade foi constatado que, embora vários entrevistados afirmassem que classificavam as peças em "primeira", "segunda" etc., nenhum deles indicou a utilização de normas e especificações de instituições reconhecidas ou que sejam aceitas amplamente pelo mercado em geral.

Essa situação é reconhecida como um dos fatores que impedem o comércio e a utilização mais intensa e racional da madeira serrada/beneficiada. Portanto, é importante que padronizações de dimensões e de classificação das peças sejam estabelecidas e efetivamente utilizadas.

Foi observado que a maior parte dos entrevistados não utiliza tratamento químico preservante. Há diversas espécies de baixa durabilidade natural em uso e aquelas duráveis, são utilizadas com alburno presente nas peças. Tal situação é preocupante, face a expansão dos problemas de deterioração da madeira causados por insetos, na Cidade de São Paulo. É necessário que as construtoras se conscientizem sobre o problema para que medidas preventivas sejam tomadas.

Os problemas gerais existentes no setor e relatados pelos distribuidores e construtoras estão relacionados principalmente a questões de comercialização e de qualidade. Dentre as questões de comercialização, 
destacam-se o alto custo da madeira e do transporte. Nas questões relativas à qualidade destacam-se deficiência na secagem e no processamento (mal serrada), presença de defeitos naturais, ausência de padronização de dimensōes e de classificação, e a mistura de espécies.

Qualquer ação para aprimorar o uso da madeira deve considerar que os distribuidores são peça importante no abastecimento do mercado de madeira serrada/beneficiada para a construção civil habitacional. Já nas construtoras o projetista é a peça chave a ser objetivada nessas ações, seguido pelos encarregados de aquisição de materiais.

$\mathrm{Na}$ pesquisa bibliográfica conduzida para se obter as informações tecnológicas necessárias para o agrupamento das espécies por uso final, detectou-se a deficiência total ou quase total de informações para sete espécies de madeira.

Várias madeiras têm ausência de informações sobre fixação mecânica (22 espécies), trabalhabilidade (11 espécies) e durabilidade natural e tratabilidade (seis espécies). Sete espécies com durabilidade natural baixa não têm dados disponíveis sobre a tratabilidade (retenção e penetração) de seus cernes.

As instituições de pesquisa que trabalham com tecnologia de madeira deveriam incluir em suas programações de estudos um espaço para a obtenção das informações acima relacionadas. Também é necessário um esforço dessas instituições na direção da padronização dos ensaios, o que permitiria uma divisão da carga de trabalho a ser executada e a comparação dos resultados obtidos em seus diferentes trabalhos.

Os agrupamentos de usos realizados, tendo como base o uso apontado pelos entrevistados e pelo critério proposto, revelaram que os grupos com características estruturais (leve externo e interno estrutural, e pesado interno) reúnem a maior quantidade de espécies de madeira. Isto se 
constitui em mais uma evidência de que esses grupos são mais promissores para 0 agrupamento.

O critério proposto para classificar as madeiras nos grupos de usos finais, tendo como base as propriedades de madeiras tradicionais no mercado, revelou-se satisfatório.

Entre 20 a $30 \%$ das madeiras que foram alocadas nos grupos atenderam a todas as exigências estabelecidas. Para as demais houve deficiência ou ausência de informaçōes para as propriedades listadas acima. Neste quadro, o grupo "assoalhos domésticos" foi exceção, pois somente uma espécie cumpriu todas as exigências de classificação. Isto ocorreu devido a ausência de informações sobre fixação mecânica e a estabilidade dimensional abaixo dos limites estabelecidos.

Comparando os agrupamentos feitos segundo as indicações de uso dos entrevistados com aqueles com critério de classificação, verificaram-se discrepâncias, principalmente, nos grupos "leve externa e interna estrutural" e "leve, em esquadria", em função da restrição para madeiras com densidade de massa acima de $800 \mathrm{~kg} / \mathrm{m}^{3}$ e da presença de espécies com propriedades abaixo dos limites estabelecidos.

Desta forma, pode-se afirmar que os valores das propriedades para classificação, estabelecidos a partir de madeiras tradicionais com desempenho de bom a excelente, pode ter restringido a classificação de algumas espécies de madeira nos grupos de uso final.

Em função disso, recomenda-se, que em novos estudos sobre agrupamento de madeiras, seja feita uma revisão dos níveis mínimo e/ou máximo das propriedades exigíveis em cada grupo de uso, podendo-se, inclusive, estabelecer mais de um nivel de classificação dentro de um mesmo grupo.

Finalmente, cabe mencionar que os problemas apontados ao longo deste trabalho reforçam o preconceito relativo à madeira como 
material de construção, não estimulando os setores produtivo e de engenharia a buscarem o aprimoramento técnico na produção e na utilização da madeira. Como conseqüência, dá-se pouco valor econômico e ambiental às nossas florestas, o que acaba realimentando negativamente o sistema.

O desafio que se impõe aos engenheiros florestais e civís, aos tecnologistas de madeira e aos setores de produção, comércio e utilização de madeira, é de quebrar o círculo vicioso em que se encontra o setor, para que se possam gerar produtos adequados aos usos na construção habitacional e parar com o imenso desperdício florestal que se pratica neste País carente de habitações. 


\section{REFERÊNCIAS BIBLIOGRÁFICAS}

ABRIL CULTURAL, São Paulo. Nosso século; a era dos bacharéis - partes primeira e segunda. São Paulo, 1985. 2v.

ALFONSO, V.A. Caracterização anatômica do lenho e da casca das principais espécies de Eucalyptus L'Hérit cultivados no Brasil, 1987. 188p. il. (Doutorado - Instituto de Biociências/USP).

AMERICAN WOOD PRESERVER'S ASSOCIATION-AWPA. Wood for commercial-residential construction preservative treatment by pressure processes. C15-92. Woodstock, AWPA, 1992, 2p.

ANDRADE, E.N. de. O problema florestal do Brasil. São Paulo, O Estado de São Paulo, 1923. 104p.

ASSOCIAÇÃO BRASILEIRA DE NORMAS TÉCNICAS-ABNT. SI - Prescrições para a sua aplicação. NBR 12230. Rio de Janeiro, ABNT, 1992, 24p.

ASSOCIAÇÃO BRASILEIRA DE PRODUTORES DE MADEIRAS-ABPM.' Perfil de consumo de produtos de madeira; processamento mecânico. São Paulo, ABPM, 1989a. 32p.

ASSOCIAÇÃO BRASILEIRA DE PRODUTORES DE MADEIRAS-ABPM. Diagnóstico do subgrupo produção, extração e beneficiamento de madeiras; câmara setorial do complexo industrial moveleiro. São Paulo, ABPM, 1989b. 32p.

AZEREDO, N.R.S. de. O Brasil e o mercado brasileiro de produtos de madeiras. São Paulo, ABPM, 1987. 29p.

BARRETO P.G., UHL C., YARED Y. O potencial de produção sustentável de madeira em Paragominas -PA; na Amazônia Oriental: considerações 
ecológicas e econômicas. In: CONGRESSO FLORESTAL PANAMERICANO, 1., e CONGRESSO FLORESTAL BRASILEIRO, 7., Curitiba, 1993. Anais. Curitiba, SBS e SBEF, 1993. vol.1, p. 387-392.

BELLO, W. \& SILVA, M. da. Exploração de Madeiras. Rio de Janeiro, Sociedade Nacional de Agricultura, 1908. 107p.

BORTOLETTO JR., G. \& LAHR, F.A.R. Aplicação da madeira de pinus na construção civil. In: CONGRESSO FLORESTAL PANAMERICANO, 1., e CONGRESSO FLORESTAL BRASILEIRO, 7., Curitiba, 1993. Anais. Curitiba, SBS e SBEF, 1993. vol.2, p. 585-587.

CHIMELO, J.P. \& ALFONSO, V.A. Anatomia e identificação de madeiras. In: INSTITUTO DE PESQUISAS TECNOLÓGICAS DO ESTADO DE SÃO PAULO-IPT. Madeira: o que é e como pode ser processada e utilizada. São Paulo, Associação Brasileira de Preservadores de Madeira, 1985. p. 23-58. (Boletim ABPM 36).

CHIMELO, J.P. \& HUMPHREYS, R.D. Comparação entre propriedades físicas, mecânicas e estereológicas para agrupamento de madeiras. Revista do Instituto Florestal. Anais do $2^{\circ}$ Congresso Sobre Essências Nativas, São Paulo, 1992. São Paulo, 4(parte 2):480-490, 1992. Edição especial. CHIMELO, J.P.; ZENID, G.J.; MIRANDA, M.J.A.C.; CECCANTINI, G.C.T. IMAC - Identificação de madeiras brasileiras com auxílio do computador. In: CONGRESSO FLORESTAL PANAMERICANO, 1., e CONGRESSO FLORESTAL BRASILEIRO, 7., Curitiba, 1993. Anais. Curitiba, SBS e SBEF, 1993. vol.2, p. 641-643.

CORDEIRO, L.E., MONTEIRO, L.V., TOMAZELLO Fº, M. Descrição macro e microscópica das madeiras comercializadas no município de Piracicaba. In: CONGRESSO NACIONAL DE BOTÂNICA, XLVI, Ribeirão Preto, 1995. Resumos. Ribeirão Preto, SBB e FFCLRP-USP, 1995. P.36. 
CORE, H.A.; CÔTÉ, W.A.; DAY, A.C. Wood structure and identification. Syracuse, Syracuse University Press, 1976. 168p. (Syracuse wood science series, 6)

ELLIOTT, G.K. Response to Europe and the green. In: TIMBER TRADING 90, TTJ'S INTERNATIONAL CONFERENCE, 7., Londres, 1990. Conference papers. Londres, Timber Trades Journal, 1990. p.11-131.

FARAH, M.F.S. Tecnologia, processo de trabalho e construção habitacional. São Paulo, 1992. 297p. (Doutorado - Faculdade de Filosofia, Letras e Ciências Humanas/USP).

FEDALTO, L.C.; MENDES, I.C.A.; CORADIN, V.T.R. Madeiras da amazônia: descrição do lenho de 40 espécies ocorrentes na floresta nacional do Tapajós. Brasília, IBAMA, 1989. 156p.

FREITAS, A. R. de. Probabilistc approach in the design of wood structures in Brazil based on the variability of 23 species. Blacksburg, VPI \& SU, 1978. 80p. (Wood Construction Bulletin, 159).

FREITAS, A. R. de. Potencial de utilização de madeiras em construções. In: ENCONTRO BRASILEIRO EM PRESERVAÇÃO DE MADEIRAS, 1., São Paulo, 1982. Anais. São Paulo, ABPM, 1982. p.9-13.

FREITAS, A. R. de. Madeira: material nobre, pouco valorizado no Brasil. In: ASSOCIAÇÃO BRASILEIRA DE DESENHISTAS DE INTERIORES E DECORADORES - ABDID. Madeira na arquitetura, construção e mobiliário. São Paulo, Ed. Projeto, 1988. p.17-26.

FUNNELL, J.E. Materials substitution - once an option, now a necessity. In: CONFERENCIA INTER-AMERICANA DE TECNOLOGIA DE MATERIAIS, 5., São Paulo, 1978. Anais. São Paulo, IPT, 1978. p.289-296.

GAMA e SILVA, Z.A.G.P. da \& BRAZ, E.M. Identificação do custo de produção do manejo florestal sustentado e seus reflexos nas serrarias do estado do Acre. In: CONGRESSO FLORESTAL PANAMERICANO, 1., e 
CONGRESSO FLORESTAL BRASILEIRO, 7., Curitiba, 1993. Anais. Curitiba, SBS e SBEF, 1993. vol.1, p. 363-366.

HANSOM, P.O. Promotion of commercially less accepted species. In: CONSULTATION ON THE WOOD AND WOOD PRODUCTS INDUSTRY, 1. Helsinki, 1983. s.I., UNIDO/FAO, 1983, 40p. (ID/WG.395/1).

HENG, 0.S. Some notes on grouping of species for standardization of timber properties. Sandakan, Forest Research Centre, 1988. 23p. (FRC Publication no. 46).

HEYWOOD, V.H. Taxonomia vegetal. Trad. K. G. Hell. São Paulo, Ed. Nacional e EDUSP, 1970. 107p. (Estudos de biologia, 5).

INSTITUTO BRASILEIRO DE DESENVOLVIMENTO FLORESTAL-IBDF. Madeiras da Amazônia: características e utilização; volume I - Floresta Nacional do Tapajós. Brasília, CNPq, 1981. 113p.

INSTITUTO BRASILEIRO DE DESENVOLVIMENTO FLORESTAL-IBDF. Potencial madeireiro do Grande Carajás. Brasília, IBDF, 1983. 134p.

INSTITUTO BRASILEIRO DE DESENVOLVIMENTO FLORESTAL-IBDF. Identificação e agrupamento de espécies de madeiras tropicais amazônicas; síntese. Brasília, IBDF, 1985. 59p.

INSTITUTO BRASILEIRO DE DESENVOLVIMENTO FLORESTAL-IBDF.

Padronização da nomenclatura comercial brasileira das madeiras tropicais amazônicas. Brasília, IBDF, 1987. 85p.

INSTITUTO BRASILEIRO DE DESENVOLVIMENTO FLORESTAL-IBDF. Madeiras da Amazônia: características e utilização; volume II - Estação experimental de Curuá-Una. Brasília, IBDF, 1988. 236p.

INSTITUTO BRASILEIRO DO MEIO AMBIENTE E DOS RECURSOS NATURAIS RENOVÁVEIS-IBAMA \& FUNDAÇÃO PRÓ-NATUREZAFUNATURA. Diagnóstico dos setor florestal brasileiro, região Sudeste. Sumário Executivo. Rio de Janeiro, IBAMA/FUNATURA, 1995. 
INSTITUTO DE PESQUISAS TECNOLÓGICAS DO ESTADO DE SÃO PAULOIPT. Sistema de informações de madeiras brasileiras. São Paulo, IPT, 1989. 291p. (Relatório № 27.078)

INSTITUTO DE PESQUISAS TECNOLÓGICAS DO ESTADO DE SÃO PAULOIPT. Identificação de espécies de madeira. São Paulo, IPT, 1993. 34p. (Relatório № 31.832)

INSTITUTO NACIONAL DE PESQUISAS DA AMAZÓNIA-INPA. Catálogo de madeiras da Amazônia: Características tecnológicas; área da hidrelétrica de Balbina. Manaus, INPAVCNPq, 1991. 88p.

KEATING, W.G. Improving the utilization of tropical species through grouping techniques. In: SEMINAR ON UTILIZATION OF NON-TRADITIONAL TROPICAL SPECIES, São Paulo, 1983. São Paulo, s.ed., 1983, 31p.

KEENAN, F.J. \& TEJADA, M. Tropical timber for building materials in the andean group countries of south america. Ottawa, Ontario, International Development Research Centre-IDRC, 1984. 151p.

KRONKA, F.J.N.; MATSUKUMA, C.K.; NALON, M.A.; CALI, I.H.; ROSSI, M.; MATTOS, I.F.A.; PONTINHAS, A.A.S.; SHIN IKE, M.S. Inventário florestal do estado de São Paulo. In: CONGRESSO FLORESTAL PANAMERICANO, 1., e CONGRESSO FLORESTAL BRASILEIRO, 7 ., Curitiba, 1993. Anais. Curitiba, SBS e SBEF, 1993. vol.2, p. 520-521.

LELIS, A.T. \& LOPEZ, G.A.C. O perigo mora aqui dentro. Téchne, São Paulo, 4: 17-19, maio/junho, 1993.

MAEGLIN, R.R. Sawmilling. In: MAEGLIN, R.R., ed. Forest products from Latin America; An almanac of the state of the knowledge and the state of the art. Madison, U.S. Department of Agriculture, Forest Service, Forest Products Laboratory, 1991. p.63-75.

MAINIERI, C. \& CHIMELO, J.P. Fichas de características das madeiras brasileiras. 2.ed. São Paulo, IPT, 1989. 418p. (publicação IPT 1791). 
MAINIERI, C.; CHIMELO, J.P.; ALFONSO, V.A. Manual de identificação das principais madeiras comerciais brasileiras. São Paulo, IPT, 1983. 241p. (publicação IPT 1226).

MELO, J.E de. Classes de tensões para nove espécies de madeiras brasileiras. In: ENCONTRO BRASILEIRO EM MADEIRAS E EM ESTRUTURAS DE MADEIRA, $1^{\circ}$, São Carlos, 1986. Anais. São Carlos, USP-EESC-SETLaMEM, 1986. vol.1, p.239-254.

MELO, J.E de; CORADIN, V.T.R; MENDES, J.C. Classes de densidade para madeiras da Amazônia brasileira. In: CONGRESSO FLORESTAL BRASILEIRO, 6., Campos do Jordão, 1990. Anais. São Paulo, SBS e SBEF, 1990. p.695-699.

MENGEL, R. Por que novas tecnologias não saem do protótipo? Jornal da USP, São Paulo, 16 a 21 novembro 1993. p.10-11.

MONTEIRO, L.V., CORDEIRO, L.E., TOMAZELLO Fo ${ }^{\circ}$ M. Levantamento das espécies de madeiras comercializadas no municipio de Piracicaba. In: CONGRESSO NACIONAL DE BOTÂNICA, XLVI, Ribeirão Preto, 1995. Resumos. Ribeirão Preto, SBB e FFCLRP-USP, 1995. P.36.

NAHUZ, M.A.R. Some aspects of the introduction of lesser-known brazilian species to the european timber market. Bangor, 1974. 244p. (M. Sc. University College of North Wales).

NAHUZ, M.A.R. Levantamento do potencial madeireiro do estado de São Paulo. São Paulo, IPT, 1975. 88p. (Relatório № 8.472).

NAHUZ, M.A.R. Obtenção de materiais primários para a indústria de habitação: madeira. In: CONFERÊNCIA INTER-AMERICANA DE TECNOLOGIA DE MATERIAIS, 5., São Paulo, 1978. Anais. São Paulo, IPT, 1978. p.239-244. NOGUEIRA, M.C.J.A. Indicações para o emprego de dezesseis espécies de eucalipto na construção civil, 1991. 116p. (Mestrado - Escola de Engenharia de São Carlos/USP). 
PANSHIN, A.J. \& DE ZEEUW, C. Textbook of wood technology. 3.ed. New York, Mcgraw-Hill, 1970. 705p.

PEREIRA, H. Apontamento sobre as madeiras do estado de S. Paulo. 5.ed. São Paulo, Espindola, 1914. 136p.

PEREIRA, J.A. Contribuição para a identificação micrographica das nossas madeiras. São Paulo, Escola Polytéchnica de São Paulo-Laboratório de Ensaios de Materiais, 1933. 165p. (Boletim $n^{\circ} 9$ ).

PEREZ, A.R. \& KAWAZOE, L. Sistema construtivo em madeira. In: Tecnologia de edificações - projeto de divulgação Lix da Cunha. São Paulo, PINI, IPT, 1988. cap. 2, p.187-192.

RIBAS, O. Bird critica crescimento a qualquer custo. O Estado de São Paulo, São Paulo, 17 maio 1992. Caderno de economia, p.6.

RIVOLI, G.; KOLJONEN, K.; NASCIMENTO, P.R.; MERCADO, R.S. A aplicação da madeira e seus derivados na construção habitacional. Brasília, Instituto Brasileiro de Desenvolvimento Florestal-IBDF, 1978. 129p. (Coleção desenvolvimento e planejamento florestal, série técnica, 9)

RODRIGUES, J. Uso errado do material dá prejuizo de $20 \%$. Folha de São Paulo, São Paulo, 10 maio 1992.

SOCIEDADE BRASILEIRA DE SILVICULTURA-SBS. Indústria de madeira serrada. São Paulo, SBS, s.d. 14p. (Documento de trabalho do grupo de planejamento estratégico florestal - GPEF).

SOCIEDADE BRASILEIRA DE SILVICULTURA-SBS. A sociedade brasileira e seu patrimônio florestal. São Paulo, SBS, 1990. 19p.

SODRÉ, J.A.C.; \& OLIVEIRA, A.M.F. Utilização das componentes principais para análise de dados multivariados. In: SEMINÁRIO LATINO AMERICANO SOBRE UTILIZAÇÃO DE MADEIRAS TROPICAIS, São Paulo, 1983. São Paulo, s.ed., 1983, 14p.

SUCHEK, V.I. Alternativas de industrialização de madeiras de reflorestamento. São Paulo, JP Engenharia, 1989. 40p. 
SUPERINTENDÊNCIA DO DESENVOLVIMENTO DA AMAZÔNIA- SUDAM. Grupamento de espécies tropicais da amazônia por similaridade de características básicas e por utilização. Belém, SUDAM, 1981. 237p. (convênio SUDAM/IPT).

TEIXEIRA, D.E; SANTANA, M.A.E.; SOUZA, M.R. de. Amazonian timbers for the International market. Brasília, IBDF/ITTO, 1988. 94p (ITTO Technical Series 1).

TEREZO, E.F. de M. As indústrias na amazônia e o uso dos recursos florestais. In: CONGRESSO FLORESTAL BRASILEIRO, 6., Campos do Jordão, 1990. Trabalhos convidados. São Paulo, SBS e SBEF, 1990. p.19-24.

TOMASELLI, I.\& SILVA, L.B.X. Grevillea, cinamomo e outras madeiras. In: SEMINÁRIO SOBRE PROCESSAMENTO E UTILIZAÇÃO DE MADEIRAS PARA REFLORESTAMENTO, IV,. Curitiba,1996., Anais. Curitiba, ABPM e SBS, 1996. p.5-18.

UNITED NATIONS INDUSTRIAL DEVELOPMENT ORGANIZATION-UNIDO. Measures to promote the use of wood and wood products; issue paper n'2. In: CONSULTATION ON THE WOOD AND WOOD PRODUCTS INDUSTRY, 1. Helsinki, 1983. s.I., UNIDO/FAO, 1983, 15p. (IDNG.395/8).

WATSON, L.A. Natural and cultural resources conservation in Parana, Brazil. Calgary, 1980. 223p. (Master of Arts - The University of Calgary).

WEBSTER, C. Timber selection by properties; the species for the job, part 1 windows, doors, cladding and flooring. London, HMSO, 1978. 125p.

WOLFE, R.W. Engineered Uses. In: MAEGLIN, R.R., ed. Forest products from Latin America; An almanac of the state of the knwoledge and the state of the art. Madison, U.S. Department of Agriculture, Forest Service, Forest Products Laboratory, 1991. p.121-128.

ZENID, G.J. Noções de classificação de toras e de madeira serrada. São Paulo, IPT, 1990. 62p. (publicação IPT 1815). 


\section{APÊNDICE 1}




\section{LISTA DE EMPRESAS DISTRIBUIDORAS DE MADEIRA}

As empresas distribuidoras de madeira visitadas para a coleta de informações estão listadas a seguir, de acordo com o bairro em que se localizam.

\section{BAIRRO DO LIMÃO}

- ACÁCIA MERCANTIL MADEIREIRA LTDA.

- ESPAÇO 4 COMÉRCIO E REPRESENTAÇÕES LTDA.

- GIL MADEIRAS E MATERIAIS DE CONSTRUÇÃO LTDA.

- MADEIREIRA JOARA LTDA.

- SERRARIA PARECIS LTDA.

\section{BRÁS}

- A g MADEIRAS LTDA.

- CAPRICÓRNIO S/C LTDA.

- COMERCIAL DE MADEIRAS PAULISTA LTDA.

- FIMAC COMÉRCIO DE MADEIRAS LTDA.

- MADEIRAS LANE LTDA.

- MATOPÁ MADEIRAS LTDA.

- SERRA COMERCIAL MADEIREIRA LTDA. 
- TARIMATÃ COMÉRCIO DE MADEIRAS LTDA. BROOKLIN

- MOGNO SUL MADEIRAS LTDA.

\section{BUTANTÃ}

- ALPHA PISO DESIGN HOUSE DECORAÇÓES LTDA.

- ALPHAMADE

- CARPAN DESIGN \& PROJETOS LTDA.

- CISAN ESQUADRIAS DE IMPORTAÇÃo

- DOIS PODERES

- ESQUADRIAS ALVARENGA LTDA.

- KISMEL PORTAS E JANELAS

- MASBRA

- PAU PAU ASSOALHOS E CIA.

- READ COMÉRCIO dE MADEIRAS LTDA.

- REATA

- ROMAPPA COMÉRCIO E REPRESENTAÇÕES DE MADEIRAS LTDA.

INTERLAGOS

- PINHOFER MADEIRAS E DERIVADOS IPIRANGA

- MADEPLAC CENTRAL DE MADEIRAS JARDIM BOFLIGLIOLI

- MADEIRAS LANE LTDA. JARDIM DA SAÚDE

- GONZALEZ MADEIREIRA LTDA. PINHEIROS

- ARATANS COMERCIAL MADEIREIRA LTDA. 
- CASA DAS TRELIÇAS MADEIRAS E FERRAGENS LTDA.

- ITAFERR MADEIRAS E FERRAGENS LTDA.

- MADEIRAS PINHEIRO LTDA.

- PAULIMAD COMÉRCIO DE MADEIRAS LTDA. RIO BONITO

- MADEIREIRA RIO BONITO

\section{SANTO AMARO}

- CAPITEL COMÉRCIO DE MADEIRAS E MATERIAIS P/ CONSTRUÇÃO LTDA.

- DEPÓSITO CAMPO GRANDE MATERIAIS PI CONSTRUÇÃO LTDA.

- LAJOTEIRO COMÉRCIO dE MATERIAIS PARA CONSTRUÇĀO LTDA.

\section{VILA GUMERCINDO}

- COMINOTTI COMÉRCIO DE MADEIRAS LTDA.

\section{VILA MARIANA}

- BAY WINDOW COMÉRCIO DE MADEIRAS E ESQUADRIAS LTDA.

- SPAZIO COMÉRCIO DE MADEIRAS E ESQUADRIAS LTDA.

\section{LISTA DE EMPRESAS CONSTRUTORAS}

As empresas construtoras cujas obras foram visitadas para a coleta de informações estão listadas a seguir, de acordo com o bairro em que se localizam as obras. Exceto para três empresas, as demais obras localizam-se na Cidade de São Paulo. 


\section{CERQUEIRA CÉSAR}

- CONSTRUTORA JACEGUAVA

- CONSTRUTORA KAUFFMANN LTDA.

- CONSTRUTORA SUAREZ

- ENCOL S.A. ENGENHARIA COM \& IND

- INPAR INCORPORAÇÕES E PARTICIPAÇÕES LTDA.

- TUAMA ENGENHARIA LTDA.

\section{CONSOLAÇÃO}

- INPAR INCORPORAÇÕES E PARTICIPAÇÕES JARDIM PAULISTA

- CONSTRUTORA BORGES LANDEIRO

- GHg CONSTRUÇÓES LTDA.

- GAFISA IMOBILIÁRIA S.A.

\section{PARAÍSO}

- PINTO DE ALMEIDA ENGENHARIA

PARQUE NOVO MUNDO

- CAMARgo corREA S.A.

\section{PLANALTO PAULISTA}

- CONCIVIL CONSTRUTORA E INCORPORADORA

- MANTRA ENGENHARIA LTDA.

- TECNO \& CORPORATE EMP. IMOBILIÁRIOS

VILA MARIANA

- AÇÃo CONSTRUTORA LTDA.

\section{VILA MASCOTE}

- gAFISA IMOBILIÁRIA S.A.

VILA NOVA CONCEIÇÃO

- CONSTRUTOR: EDMUNDO AZAR 
- CONSTRUTORA RFM

\section{INTERIOR DE SÃO PAULO}

- REMA CONSTRUTORA LTDA. (Araraquara)

- ALMEIDA MARIN - CONSTRUÇÕES E COMÉRCIO (Paulínia)

- RICARDO PAPPA PROJETOS E CONSTRUÇÕES LTDA. (Salto) 
APÊNDICE 2 
1. QUESTIONÁRIO UTILIZADO NA COLETA DE INFORMAÇÕES NAS DISTRIBUIDORAS

\section{QUESTIONÁRIO - DISTRIBUIDORAS}

№ ...........

Empresa:

End::

Bairro:

CEP

Fone:

Fax:

Informante:

Cargo:

1. Espécies de madeiras serradas/beneficiadas comercializadas

\begin{tabular}{|c|c|}
\hline nome & $\%$ \\
\hline & \\
\hline & \\
\hline & \\
\hline & \\
\hline & \\
\hline & \\
\hline & \\
\hline
\end{tabular}


2. Padronização das dimensões?

$\square$ Não $\square$ Sim. Qual?

3. Padronização da qualidade?

$\square$ Não $\square$ Sim. Qual?

4.Tratamento químico?

$\square$ Não $\square$ Sim. Qual?

5. Secagem?

$\square$ Não $\square \operatorname{Sim}$

$\square$ Ar $\square$ Estufa

6. Forma de aquisição da madeira:

$\square$ produção própria $\square$ produção terceiros $\square$ distribuidor

$\square$ outras:

7. Problemas do setor

\begin{tabular}{|c|c|}
\hline problemas & peso \\
\hline & \\
\hline & \\
\hline & \\
\hline & \\
\hline & \\
\hline & \\
\hline
\end{tabular}

Data: _L_196

Entrevistador (código): 
QUESTIONÁRIO - MADEIRA № .........

Folha № ......

Código da amostra:

Nome popular:

Identificação do Laboratório:

Nome popular:

Nome científico:

Informações sobre a madeira:

1.Fonte de suprimento:

pais:

município: estado:

2. Usos:

3. Tipos de peças (nome e bitola):

4. Fixação mecânica पboa $\square$ regular $\square$ ruim

6. Desempenho em uso

abom aregular aruim

Justificar:
5. Trabalhabilidade:

aboa पregular पruim 


\section{QUESTIONÁRIO UTILIZADO NA COLETA DE INFORMAÇŌES NAS CONSTRUTORAS}

\section{QUESTIONÁRIO - CONSTRUTORAS}

№ ...........

Empresa:

\section{End.:}

Bairro:

CEP

Fone:

Fax:

Informante:

Cargo:

1. Espécies de madeiras serradas/beneficiadas utilizadas

\begin{tabular}{|l|l|}
\hline nome & $\%$ \\
\hline & \\
\hline & \\
\hline & \\
\hline & \\
\hline & \\
\hline & \\
\hline & \\
\hline & \\
\hline
\end{tabular}


2. Padronização das dimensões?

$\square$ Não $\square$ Sim. Qual?

3. Padronização da qualidade?

$\square$ Não $\square$ Sim. Qual?

4.Tratamento químico?

$\square$ Não $\square$ Sim. Qual?
5. Secagem?
$\square$ Não $\square$ Sim
$\square$ Ar $\quad$ Estufa

6. Forma de aquisição da madeira:
$\checkmark$ produção própria
$\square$ produção terceiros
$\square$ distribuidor
$\square$ outras:

7. Critério de escolha das espécies de madeira:

$\square$ projeto $\square$ tradição $\square$ vendedor/distribuidor

$\square$ disponibilidade $\square$ outras:

8. Problemas do setor

\begin{tabular}{|c|c|}
\hline problemas & peso \\
\hline & \\
\hline & \\
\hline & \\
\hline & \\
\hline
\end{tabular}

Data: ___ 196

Entrevistador: (código): 
QUESTIONÁRIO - MADEIRA № .........

Folha № ${ }^{0}$.....

Código da amostra:

Nome

popular:

Identificação do Laboratório:

Nome popular:

Nome científico:

Informações sobre a madeira:

1.Fonte de suprimento:

país:

município:

estado:

2. Usos:

3. Tipos de peças (nome e bitola):

4. Fixação mecânica $\square$ boa $\square$ regular $\square$ ruim

6. Desempenho em uso

abom पregular aruim

Justificar:
5. Trabalhabilidade:

口boa Dregular पruim 


\section{APÊNDICE 3}




\section{RESULTADO DA IDENTIFICAÇĀO DAS AMOSTRAS DE MADEIRA COLETADAS JUNTO AOS DISTRIBUIDORES}

\begin{tabular}{|c|c|c|c|c|}
\hline Quest & Amostra & Nome coletado & Identificação no l & atório \\
\hline & & & Nome comercial & Nome científico \\
\hline$A-01$ & $001-A$ & ipê & ipê & Tabebuia sp \\
\hline $\mathrm{A}-01$ & $002-A$ & marfim & pau-marfim & Balfourodendron riedelianum \\
\hline $\mathrm{A}-01$ & 003-A & sucupira & cumaru & Dipteryx odorata \\
\hline $\mathrm{A}-02$ & $004-A$ & peroba & peroba-rosa & Aspidosperma polyneuron \\
\hline $\mathrm{A}-02$ & $005-A$ & ipê & ipê & Tabebuia sp \\
\hline $\mathrm{A}-02$ & $006-A$ & jatobá & jatobá & Hymenaea courbanil \\
\hline A-03 & $007-A$ & peroba-rosa & peroba-rosa & Aspidosperma polyneuron \\
\hline A-03 & $008-A$ & pinho & pinho-do-paraná & Araucaria angustifolia \\
\hline $\mathrm{A}-03$ & 009-A & cedrinho & cedrinho & Erisma uncinatum \\
\hline A-04 & 010-A & angelim & angelim-pedra & Hymenolobium modestum \\
\hline $\mathrm{A}-04$ & 011-A & cedrinho & cedrinho & Erisma uncinatum \\
\hline $\mathrm{A}-04$ & 012-A & cedro-rosa & mogno & Swietenia macrophylla \\
\hline A-04 & 013-A & cerejeira & cerejeira & Amburana acreana \\
\hline $\mathrm{A}-04$ & 014-A & imbuia & imbuia & Ocotea porosa \\
\hline A-04 & 015-A & ipê & ipê & Tabebuia sp \\
\hline $\mathrm{A}-04$ & 016-A & jatobá & jatobá & Hymenaea stilbocarpa \\
\hline $\mathrm{A}-04$ & $017-A$ & mogno & mogno & Swietenia macrophylla \\
\hline A-05 & $018-A$ & mogno & mogno & Swietenia macrophylla \\
\hline A-05 & 019-A & imbuia & imbuia & Ocotea porosa \\
\hline $\mathrm{A}-06$ & $020-A$ & pinus & pinus & Pinus sp \\
\hline A-06 & 021-A & cedrinho & cedrinho & Erisma uncinatum \\
\hline A-07 & 022-A & mogno & mogno & Swietenia macrophylla \\
\hline A-07 & 023-A & ipê & ipế & Tabebuia sp \\
\hline A-07 & 024-A & marfim & pau-marfim & Balfourodendron riedelianum \\
\hline A-08 & $025-\mathrm{A}$ & mogno & mogno & Swietenia macrophylla \\
\hline A-08 & $026-A$ & freijó & freijó & Cordia goeldiana \\
\hline A-08 & $027-\mathrm{A}$ & pinho & pinho-do-paraná & Araucaria angustifolia \\
\hline A-08 & 028-A & marfim & pau-marfim & Balfourodendron riedelianum \\
\hline $\mathrm{A}-08$ & $029-A$ & sucupira & sucupira & Bowdichia nitida \\
\hline
\end{tabular}




\begin{tabular}{|c|c|c|c|c|}
\hline Quest & Amostra & Nome coletado & Identificação no la & atório \\
\hline & & & Nome comercial & Nome científico \\
\hline A-09 & 030-A & ipê & ipê & Tabebuia sp \\
\hline A-09 & 031-A & marfim & pau-marfim & Balfourodendron riedelianum \\
\hline A-09 & 032-A & jatobá & jatobá & Hymenaea courbaril \\
\hline A-09 & O33-A & imbuia & imbuia & Ocotea porosa \\
\hline A-09 & 034-A & cedro & cedro & Cedrela sp \\
\hline A-09 & 035-A & mogno & mogno & Swietenia macrophylla \\
\hline A-09 & 036-A & angelim & angelim-pedra & Hymenolobium heterocarpum \\
\hline$A-10$ & 037-A & cedrinho & cedrinho & Erisma uncinatum \\
\hline A-10 & 038-A & ipê & ipê & Tabebuia sp \\
\hline A-10 & 039-A & jatobá & jatobá & Hymenaea stilbocarpa \\
\hline$A-10$ & $040-A$ & cumaru & cumaru & Dipteryx odorata \\
\hline $\mathrm{A}-11$ & $041-A$ & imbuia & imbuia & Ocotea porosa \\
\hline A-11 & 042-A & cerejeira & cerejeira & Amburana acreana \\
\hline$A-11$ & 043-A & cedro-rosa & cedro & Cedrela sp \\
\hline$A-11$ & 044-A & angelim & angelim-pedra & Hymenolobium heterocarpum \\
\hline$A-12$ & 045-A & cerejeira & cerejeira & Amburana acreana \\
\hline$A-12$ & 046-A & cedro-rosa & cedrorana & Cedrelinga catenaeformis \\
\hline$A-12$ & $047-A$ & mogno & mogno & Swietenia macrophylla \\
\hline$A-12$ & 048-A & marfim & pau-marfim & Balfourodendron riedelianum \\
\hline$A-12$ & 049-A & ipê & ipê & Tabebuia sp \\
\hline$A-12$ & $050-A$ & imbuia & imbuia & Ocotea porosa \\
\hline$A-12$ & $051-A$ & sucupira & sucupira & Diplotropis guianensis \\
\hline$A-12$ & 052-A & cedrinho & cedrinho & Erisma uncinatum \\
\hline $\mathrm{A}-13$ & $053-A$ & cedrinho & cedrinho & Erisma uncinatum \\
\hline$A-13$ & 054-A & pinho & pinho-do-paraná & Araucaria angustifolia \\
\hline $\mathrm{A}-13$ & 055-A & mogno & mogno & Swietenia macrophylla \\
\hline A-13 & 056-A & imbuia & imbuia & Ocotea porosa \\
\hline A-14 & $057-A$ & cedrinho & cedrinho & Erisma uncinatum \\
\hline$A-14$ & 058-A & jatobá & jatobá & Hymenaea courbaril \\
\hline A-14 & 059-A & pinho & pinho-do-paraná & Araucaria angustifolia \\
\hline A-14 & 060-A & ipê & ipê & Tabebuia sp \\
\hline A-14 & $061-A$ & mogno & mogno & Swietenia macrophylla \\
\hline A-14 & 062-A & cerejeira & cerejeira & Amburana acreana \\
\hline$A-14$ & 063-A & pinus & pinus & Pinus sp \\
\hline A-15 & 064-A & cedrinho & cedrinho & Erisma uncinatum \\
\hline$A-15$ & 065-A & pinho & pinho-do-paraná & Araucaria angustifolia \\
\hline A-15 & 066-A & cerejeira & cerejeira & Amburana acreana \\
\hline$A-15$ & $067-A$ & mogno & mogno & Swietenia macrophylla \\
\hline A-15 & 068-A & jatobá & jatobá & Hymenaea courbaril \\
\hline A-15 & 069-A & ipê & ipê & Tabebuia sp \\
\hline A-16 & $070-A$ & cupiúba & cupiúba & Goupia glabra \\
\hline$A-17$ & 071-A & maçaranduba & maçaranduba & Manilkara longifolia \\
\hline $\mathrm{A}-17$ & $072-A$ & angico-rajado & angico-preto & Anadenanthera macrocarpa \\
\hline $\mathrm{A}-17$ & 073-A & peroba-rosa & peroba-rosa & Aspidosperma polyneuron \\
\hline $\mathrm{A}-18$ & 074-A & ipê & ipê & Tabebuia sp \\
\hline
\end{tabular}




\begin{tabular}{|c|c|c|c|c|}
\hline Quest & Amostra & Nome coletado & \multicolumn{2}{|c|}{ Identificação no laboratório } \\
\hline & & & Nome comercial & Nome científico \\
\hline A-18 & $075-A$ & jatobá & mogno & Swietenia macrophylla \\
\hline A-18 & $076-A$ & cedrinho & cedrinho & Erisma uncinatum \\
\hline$A-18$ & $077-A$ & peroba-rosa & peroba-rosa & Aspidosperma polyneuron \\
\hline A-18 & 078-A & mogno & mogno & Swietenia macrophylla \\
\hline$A-19$ & 080-A & cedrinho & cedrinho & Erisma uncinatum \\
\hline$A-19$ & $081-\mathrm{A}$ & pinho & pinho-do-paraná & Araucaria angustifolia \\
\hline$A-19$ & 082-A & peroba-rosa & peroba-rosa & Aspidosperma polyneuron \\
\hline T-01 & 000-T & cedro-rosa & cedro & Cedrela sp \\
\hline $\mathrm{T}-01$ & $001-T$ & ipê-tabaco & ipê & Tabebuia sp \\
\hline $\mathrm{T}-01$ & $002-T$ & cumaru & cumaru & Dipteryx odorata \\
\hline $\mathrm{T}-01$ & 003-T & jatobá & jatobá & Hymenaea stilbocarpa \\
\hline $\mathrm{T}-01$ & 004-T & marfim & pau-marfim & Balfourodendron riedelianum \\
\hline $\mathrm{T}-01$ & 005-T & peroba-rosa & peroba-rosa & Aspidosperma polyneuron \\
\hline T-01 & 006-T & garapa & garapa & Apuleia leiocarpa \\
\hline $\mathrm{T}-01$ & $007-T$ & ipê-sapucaia & macacaúba & Platymiscium ulei \\
\hline T-01 & 008-T & tamarino / jatai & jutai-cica & Martiodendron elatum \\
\hline T-01 & 009-T & cedrinho & cedrinho & Erisma uncinatum \\
\hline $\mathrm{T}-02$ & 010-T & cedro & cedro & Cedrela sp \\
\hline $\mathrm{T}-02$ & 011-T & imbuia & imbuia & Ocotea porosa \\
\hline T-03 & 012-T & imbuia & louro-canela & Ocotea sp \\
\hline $\mathrm{T}-03$ & 013-T & angelim-pedra & angelim-pedra & Hymenolobium elatum \\
\hline T-03 & 014-T & cerejeira & cerejeira & Amburana acreana \\
\hline $\mathrm{T}-03$ & 015-T & mogno & mogno & Swietenia macrophylla \\
\hline T-03 & 016-T & itaúba & sem amostra & não considerar \\
\hline T-03 & 017-T & louro-vermelho & louro-vermelho & Nectandra rubra \\
\hline $\mathrm{T}-03$ & 018-T & freijó & sem amostra & não considerar \\
\hline $\mathrm{T}-03$ & 019-T & peroba-rosa & peroba-rosa & Aspidosperma polyneuron \\
\hline T-03 & 020-T & cedrinho & cedrinho & Erisma uncinatum \\
\hline T-04 & 021-T & imbuia & imbuia & Ocotea porosa \\
\hline $\mathrm{T}-04$ & 022-T & cedro-rosa & mogno & Swietenia macrophylla \\
\hline T-04 & 023-T & mogno & mogno & Swietenia macrophylla \\
\hline T-04 & 024-T & cerejeira & cerejeira & Amburana acreana \\
\hline T-04 & 025-T & ipê-cumaru & cumaru & Dipteryx odorata \\
\hline T-04 & 026-T & itaúba & itaúba & Mezilaurus itauba \\
\hline T-04 & $027-T$ & perobinha & garapa & Apuleia lejocarpa \\
\hline T-05 & 028-T & imbuia & imbuia & Ocotea porosa \\
\hline T-05 & 029-T & cedro-rosa & cedro & Cedrela sp \\
\hline $\mathrm{T}-06$ & 030-T & imbuia & imbuia & Ocotea porosa \\
\hline $\mathrm{T}-06$ & 031-T & cedro-rosa & cedro & Cedrela sp \\
\hline T-06 & 032-T & itaúba & itaúba & Mezilaurus itauba \\
\hline $\mathrm{T}-07$ & 033-T & mogno & mogno & Swietenia macrophylla \\
\hline $\mathrm{T}-07$ & 034-T & cerejeira & cerejeira & Amburana acreana \\
\hline T-09 & $051-T$ & imbuia & imbuia & Ocotea porosa \\
\hline T-09 & 052-T & cedro & cedro & Cedrela sp \\
\hline T-09 & 053-T & mogno & cedrinho & Erisma uncinatum \\
\hline
\end{tabular}




\begin{tabular}{|c|c|c|c|c|}
\hline Quest & Amostra & Nome coletado & \multicolumn{2}{|c|}{ Identificação no laboratório } \\
\hline & & & Nome comercial & Nome científico \\
\hline $\mathrm{T}-10$ & 054-T & ipê & ipê & Tabebuia sp \\
\hline$T-10$ & 055-T & jatobá & jatobá & Hymenaea courbaril \\
\hline $\mathrm{T}-10$ & 056-T & cedrinho & cedrinho & Erisma uncinatum \\
\hline$T-11$ & 057-T & jatobá & jutai-cica & Martiodendron elatum \\
\hline$\overline{T-11}$ & 058-T & ipề & ipê & Tabebuia sp \\
\hline $\mathrm{T}-11$ & 059-T & cedrinho & cedrinho & Erisma uncinatum \\
\hline $\mathrm{T}-11$ & 060-T & marfim & pau-marfim & Balfourodendron riedelianum \\
\hline$T-12$ & 061-T & ipê & ipê & Tabebuia sp \\
\hline$T-12$ & 062-T & jatobá & jutai-cica & Martiodendron elatum \\
\hline $\mathrm{T}-12$ & 063-T & peroba & peroba-rosa & Aspidosperma polyneuron \\
\hline$T-12$ & 064-T & pinus & pinus & Pinus sp \\
\hline$T-12$ & 065-T & pinho & pinho-do-paraná & Araucaria angustifolia \\
\hline$T-12$ & 066-T & cedrinho & cedrinho & Erisma uncinatum \\
\hline $\mathrm{T}-12$ & 067-T & imbuia & imbuia & Ocotea porosa \\
\hline$T-12$ & 068-T & cerejeira & cerejeira & Amburana acreana \\
\hline $\mathrm{T}-12$ & 069-T & mogno & mogno & Swietenia macrophylla \\
\hline$T-12$ & 070-T & angelim & faveira-amargosa & Vatairea fusca \\
\hline $\mathrm{T}-12$ & $071-T$ & freijó & freijó & Cordia goeldiana \\
\hline$T-13$ & 072-T & $\begin{array}{l}\text { pinho-do- } \\
\text { paraná }\end{array}$ & pinho-do-paraná & Araucaria angustifolia \\
\hline$T-13$ & 073-T & pinus & pinus & Pinus sp \\
\hline $\mathrm{T}-13$ & 074-T & cedrinho & cambará & Qualea paraensis \\
\hline$T-13$ & 075-T & cambará & cedrinho & Erisma uncinatum \\
\hline $\mathrm{T}-13$ & 076-T & $\begin{array}{l}\text { peroba-do- } \\
\text { norte }\end{array}$ & cedrinho & Erisma uncinatum \\
\hline$T-13$ & 077-Ta & $\begin{array}{l}\text { abiurana, } \\
\text { goiabão, } \\
\text { peroba-do- } \\
\text { norte }\end{array}$ & cambará & Ruizterania albiflora \\
\hline$T-13$ & $077-\mathrm{Tb}$ & $\begin{array}{l}\text { abiurana, } \\
\text { goiabão, } \\
\text { peroba-do- } \\
\text { norte }\end{array}$ & piquiá & Caryocar villosum \\
\hline $\mathrm{T}-13$ & 078-T & piquiarana & piquiarana & Caryocar glabrum \\
\hline $\mathrm{T}-14$ & 079-T & cedrinho & cedrinho & Erisma uncinatum \\
\hline $\mathrm{T}-14$ & 080-T & angico-preto & jatobá & Hymenaea courbaril \\
\hline$T-14$ & 081-T & maçaranduba & maçaranduba & Manilkara huberi \\
\hline $\mathrm{T}-14$ & 082-T & garapeira & garapa & Apuleia leiocarpa \\
\hline $\mathrm{T}-14$ & 083-T & peroba-rosa & peroba-rosa & Aspidosperma polyneuron \\
\hline $\mathrm{T}-14$ & 084-T & pinho & pinho-do-paraná & Araucaria angustifolia \\
\hline$\overline{T-14}$ & 085-T & pinus & pinus & Pinus sp \\
\hline$T-14$ & 086-T & ipê & ipê & Tabebuia sp \\
\hline$T-15$ & 087-Ta & ipê & ipê & Tabebuia sp \\
\hline$T-15$ & $087-\mathrm{Tb}$ & ipê & ipê & Tabebuia sp \\
\hline $\mathrm{T}-15$ & 087-TC & ipê & ipê & Tabebuia sp \\
\hline $\mathrm{T}-15$ & 088-T & angelim-pedra & angelim-pedra & Hymenolobium heterocarpum \\
\hline
\end{tabular}




\begin{tabular}{|c|c|c|c|c|}
\hline Quest & Amostra & Nome coletado & Identificação no labo & atório \\
\hline & & & Nome comercial & Nome cientifico \\
\hline $\mathrm{T}-15$ & 089-T & marfim & pau-marfim & Balfourodendron riedelianum \\
\hline$T-15$ & 090-T & peroba-mica & peroba-mica & Aspidosperma macrocarpon \\
\hline $\mathrm{T}-15$ & 091-T & abiurana & goiabão & Planchonella pachycarpa \\
\hline $\mathrm{T}-15$ & $092-T$ & - & sem amostra & não considerar \\
\hline$T-15$ & 093-T & cabreúva & cabreúva-vermelha & Myroxylon balsamum \\
\hline$T-15$ & 094-T & amarelinho & pau-amarelo & Euxylophora paraensis \\
\hline $\mathrm{T}-15$ & 095-T & muirajuba & pau-mulato & Calycophyllum spruceanum \\
\hline $\mathrm{T}-15$ & 096-Ta & cumaru & cumaru & Dipteryx odorata \\
\hline$T-15$ & 096-Tb & cumaru & cumaru & Dipteryx odorata \\
\hline$T-15$ & 097-T & grapia & garapa & Apuleia leiocarpa \\
\hline$T-15$ & 098-Ta & jatobá & jatobá & Hymenaea courbaril \\
\hline $\mathrm{T}-15$ & 098-Tb & jatobá & jatobá & Hymenaea courbanil \\
\hline$T-15$ & $099-\mathrm{T}$ & muiracatiara & jutai-cica & Martiodendron elatum \\
\hline $\mathrm{T}-15$ & $100-T$ & tatajuba & tatajuba & Bagassa guianensis \\
\hline$T-15$ & 101-T & angico-preto & angico-preto & Anadenanthera macrocarpa \\
\hline $\mathrm{T}-15$ & $102-T$ & tauari & tauari & Couratanisp \\
\hline $\mathrm{T}-15$ & 103-Ta & cedrinho & cedrinho & Erisma uncinatum \\
\hline $\mathrm{T}-15$ & 103-Tb & cedrinho & quaruba & Vochysia vismiaefolia \\
\hline $\bar{T}-15$ & 104-T & $\begin{array}{l}\text { marupá, } \\
\text { caixeta }\end{array}$ & marupá & Simarouba amara \\
\hline $\mathrm{T}-15$ & $105-T$ & cedro-rosa & cedro & Cedrela sp \\
\hline $\mathrm{T}-15$ & 106-T & freijó & freijó & Cordia goeldiana \\
\hline$T-16$ & $107-T$ & cedrinho & cedrinho & Erisma uncinatum \\
\hline $\mathrm{T}-16$ & 108-T & peroba-rosa & peroba-rosa & Aspidosperma polyneuron \\
\hline $\mathrm{T}-16$ & 109-T & peroba-mica & peroba-mica & Aspidosperma macrocarpon \\
\hline$T-16$ & $110-T$ & angico-preto & angico-preto & Anadenanthera macrocarpa \\
\hline $\mathrm{T}-16$ & 111-T & grevilha & grevílea & Grevillea robusta \\
\hline $\mathrm{T}-17$ & 112-T & peroba-rosa & peroba-rosa & Aspidosperma polyneuron \\
\hline $\mathrm{T}-17$ & 113-T & cedrinho & cedrinho & Enisma uncinatum \\
\hline $\mathrm{T}-17$ & 114-T & canafístula & canafístula & Peltophorum vogelianum \\
\hline $\mathrm{T}-17$ & 115-T & garapeira & garapa & Apuleia leiocarpa \\
\hline $\mathrm{T}-18$ & $116-\mathrm{T}$ & garapa & garapa & Apuleia leiocarpa \\
\hline $\mathrm{T}-18$ & $117-\mathrm{T}$ & canjerana & marinheiro & Guarea grandifolia \\
\hline$T-18$ & 118-T & $\begin{array}{l}\text { mogno- } \\
\text { marinheiro }\end{array}$ & jacareúba & Calophyllum brasiliense \\
\hline $\mathrm{T}-18$ & 119-T & cedro-rosa & cedro & Cedrela sp \\
\hline $\mathrm{T}-18$ & 120-Ta & imbuia & imbuia & Ocotea porosa \\
\hline$T-18$ & $120-\mathrm{Tb}$ & imbuia & cerejeira & Amburana acreana \\
\hline$T-18$ & 121-T & angelim & angelim-pedra & Hymenolobium heterocarpum \\
\hline$T-18$ & 122-T & canelão & louro-canela & Ocotea sp \\
\hline $\mathrm{T}-19$ & 123-T & cambará & cedrinho & Erisma uncinatum \\
\hline $\mathrm{T}-19$ & 124-T & peroba-rosa & peroba-mica & Aspidosperma macrocarpon \\
\hline$T-20$ & 125-Ta & cedrinho & cedrinho & Erisma uncinatum \\
\hline $\mathrm{T}-20$ & $125-\mathrm{Tb}$ & cedrinho & cedrorana & Cedrelinga catenaeformis \\
\hline $\mathrm{T}-20$ & $126-\mathrm{T}$ & peroba-rosa & peroba-rosa & Aspidosperma polyneuron \\
\hline
\end{tabular}




\begin{tabular}{|c|c|c|c|c|}
\hline Quest & Amostra & Nome coletado & \multicolumn{2}{|c|}{ Identificação no laboratório } \\
\hline & & & Nome comercial & Nome científico \\
\hline T-20 & 127-T & pinus & pinus & Pinus sp \\
\hline$T-21$ & 128-T & pinho & pinho-do-paraná & Araucaria angustifolia \\
\hline $\mathrm{T}-21$ & 129-T & maçaranduba & maçaranduba & Manilkara huberi \\
\hline T-21 & 130-T & $\begin{array}{l}\text { pinho- } \\
\text { reflorestado }\end{array}$ & cupressus & Cupressus lusitanica \\
\hline T-21 & 131-T & cedrinho & cedrinho & Erisma uncinatum \\
\hline T-22 & 132-T & pinho & pinho-do-paraná & Araucaria angustifolia \\
\hline $\mathrm{T}-22$ & 133-T & pinus & pinus & Pinus sp \\
\hline $\mathrm{T}-22$ & 134-T & cupiúba & cupiúba & Goupia glabra \\
\hline$T-22$ & 135-T & cedrinho & cedrinho & Erisma uncinatum \\
\hline$T-23$ & $136-T$ & eucalipto & eucalipto & Eucalyptus grandis \\
\hline$T-23$ & $137-T$ & cedrinho & cedrinho & Erisma uncinatum \\
\hline $\mathrm{T}-23$ & $138-T$ & pinus & pinus & Pinus sp \\
\hline$T-23$ & 139-T & garapeira & garapa & Apuleia leiocarpa \\
\hline T-24 & 140-T & cedrinho & cedrinho & Erisma uncinatum \\
\hline T-24 & $141-T$ & pinus & pinus & Pinus sp \\
\hline$T-24$ & 142-T & peroba-rosa & peroba-rosa & Aspidosperma polyneuron \\
\hline T-24 & 143-T & pinho & pinho-do-paraná & Araucaria angustifolia \\
\hline$T-24$ & $144-\mathrm{T}$ & cabreúva & cabreúva-vermelha & Myroxylon balsamum \\
\hline $\mathrm{T}-24$ & 145-T & ipê & ipê & Tabebuia sp? \\
\hline $\mathrm{T}-24$ & 146-T & jatobá & jatobá & Hymenaea courbaril \\
\hline $\mathrm{T}-24$ & 147-T & cumaru & cumaru & Dipteryx odorata \\
\hline $\mathrm{T}-24$ & 148-T & cambará & cambará & Qualea homosepala \\
\hline $\mathrm{T}-24$ & 149-T & pau-marfim & pau-marfim & Balfourodendron riedelianum \\
\hline T-24 & $150-\mathrm{T}$ & mogno & mogno & Swietenia macrophylla \\
\hline $\mathrm{T}-24$ & $151-\mathrm{T}$ & angelim & angelim-pedra & Hymenolobium heterocarpum \\
\hline T-24 & 152-T & $\begin{array}{l}\text { peroba-do- } \\
\text { norte }\end{array}$ & angico-vermelho & Parapiptadenia rigida \\
\hline
\end{tabular}

\section{RESULTADO DA IDENTIFICAÇÃO DAS AMOSTRAS DE MADEIRA COLETADAS JUNTO ÀS CONSTRUTORAS}

\begin{tabular}{|l|l|l|l|l|}
\hline Quest & Amostra. & Nome coletado & \multicolumn{2}{|l|}{ Identificação no laboratório } \\
\hline & & & Nome comercial & Nome científico \\
\hline I-01 & $001-\mathrm{la}$ & peroba-rosa & peroba-rosa & Aspidosperma polyneuron \\
\hline $\mathrm{I}-01$ & $001-\mathrm{lc}$ & peroba-rosa & peroba-rosa & Aspidosperma polyneuron \\
\hline $\mathrm{I}-01$ & $001-\mathrm{ld}$ & peroba-rosa & peroba-rosa & Aspidosperma polyneuron \\
\hline $1-01$ & $001-\mathrm{le}$ & peroba-rosa & peroba-rosa & Aspidosperma polyneuron \\
\hline $\mathrm{I}-01$ & $001-\mathrm{lb}$ & peroba-rosa & eucalipto & Eucalyptus tereticomis \\
\hline $\mathrm{I}-01$ & $002-\mathrm{la}$ & cedrinho & cedrinho & Erisma uncinatum \\
\hline $\mathrm{I}-01$ & $002-\mathrm{lb}$ & cedrinho & cambará & Qualea sp \\
\hline
\end{tabular}




\begin{tabular}{|c|c|c|c|c|}
\hline Quest & Amostra. & Nome coletado & \multicolumn{2}{|c|}{ Identificação no laboratório } \\
\hline & & & Nome comercial & Nome científico \\
\hline $1-01$ & $002-I c$ & cedrinho & rosadinho & Micropholis sp \\
\hline $1-02$ & $003-1 a$ & cupiúba & cupiúba & Goupia glabra \\
\hline $1-02$ & $003-1 \mathrm{~b}$ & Cupiúba & cambará & Qualea sp \\
\hline $1-02$ & $003-\mathrm{Ic}$ & cupiúba & angelim-pedra & Hymenolobium petraeum \\
\hline $1-02$ & $003-I d$ & cupiúba & cedrinho & Erisma uncinatum \\
\hline $1-02$ & $003-l e$ & cupiúba & garapa & Apuleia leiocarpa \\
\hline $\mathrm{I}-02$ & $003-$ If & cupiúba & cupiúba & Goupia glabra \\
\hline $1-03$ & $004-1$ & cupiúba & cupiúba & Goupia glabra \\
\hline $\mathrm{W}-01$ & $001-W$ & cedrinho & cedrinho & Erisma uncinatum \\
\hline W-01 & $002-W$ & pinus & pinus & Pinus sp \\
\hline$\overline{W-01}$ & $003-W$ & pinho & pinus & Pinus sp \\
\hline W-01 & $004-W$ & desconhecida & freijó & Cordia goeldiana \\
\hline $\mathrm{W}-02$ & 005-Wa & Cupiúba & louro-canela & Ocotea sp \\
\hline W-02 & $005-W b$ & cupiúba & cambará & Qualea sp \\
\hline$\overline{W-02}$ & 005-Wc & cupiúba & bacuri & Platonia insignis \\
\hline $\bar{W}-02$ & 005-Wd & cupiúba & bacuri-de-anta & Moronobea coccinea \\
\hline $\bar{W}-02$ & 005-We & cupiúba & canafístula & Peltophorum vogelianum \\
\hline W-02 & $005-\mathrm{Wf}$ & cupiúba & cupiúba & Goupia glabra \\
\hline $\mathrm{W}-02$ & $006-W$ & angico-preto & angico-preto & Anadenanthera macrocarpa \\
\hline W-02 & $007-W$ & cedrinho & eucalipto & Eucalyptus tereticomis \\
\hline W-02 & $008-W$ & cupiúba & cupiúba & Goupia glabra \\
\hline W-03 & 009-Wa & cedrinho & cambará & Ruizterania albiflora \\
\hline W-03 & $009-W b$ & cedrinho & cambará & Ruizterania albiflora \\
\hline W-03 & $009-W c$ & Cedrinho & cambará & Ruizterania albiflora \\
\hline $\mathrm{W}-03$ & $009-W d$ & cedrinho & amescla & Trattinickia burseraefolia \\
\hline W-03 & $009-W e$ & cedrinho & angelim-pedra & Hymenolobium heterocarpum \\
\hline $\mathrm{W}-03$ & $009-W f$ & cedrinho & cedrinho & Erisma uncinatum \\
\hline W-03 & $010-W$ & pinus & cuningâmia & Cunninghamia lanceolata \\
\hline W-04 & $011-W$ & pinus & pinus & Pinus sp \\
\hline $\mathrm{W}-05$ & $012-W$ & peroba-rosa & peroba-rosa & Aspidosperma polyneuron \\
\hline W-05 & $013-W$ & pinus & pinho-do-paraná & Araucaria angustifolia \\
\hline W-05 & 014-Wa & cedrinho & $\begin{array}{l}\text { fava-orelha-de- } \\
\text { negro }\end{array}$ & Enterolobium schomburgkii \\
\hline $\mathrm{W}-05$ & $014-W b$ & cedrinho & cambará & Qualea paraensis \\
\hline W-05 & $014-W_{c}$ & cedrinho & muiracatiara & Astronium lecointei \\
\hline$W-05$ & 014-Wd & cedrinho & cambará & Qualea sp \\
\hline W-05 & 014-We & cedrinho & glícia & Glycydendrom amazonicum \\
\hline W-05 & $014-W f$ & cedrinho & faveira & Dimorphandra velutina \\
\hline W-05 & $014-\mathrm{Wg}$ & cedrinho & cedrinho & Erisma uncinatum \\
\hline W-05 & $014-\mathrm{Wh}$ & cedrinho & jatobá & Hymenaea courbaril \\
\hline $\bar{W}-05$ & $014-W i$ & cedrinho & castanheira & Bertholletia excelsa \\
\hline W-05 & $015-W$ & $\begin{array}{l}\text { perobinha-do- } \\
\text { campo }\end{array}$ & bacuri-de-anta & Moronobea coccinea \\
\hline $\mathrm{W}-06$ & 016-Wa & pinho & pinho-do-paraná & Araucaria angustifolia \\
\hline $\bar{W}-06$ & $016-W b$ & pinho & pinus & Pinus sp \\
\hline
\end{tabular}




\begin{tabular}{|c|c|c|c|c|}
\hline Quest & Amostra. & Nome coletado & \multicolumn{2}{|c|}{ Identificação no laboratório } \\
\hline & & & Nome comercial & Nome científico \\
\hline $\mathrm{W}-06$ & $017-\mathrm{Wa}$ & cedrinho & cedrinho & Erisma uncinatum \\
\hline W-06 & $017-W b$ & cedrinho & muiracatiara & Astronium lecointei \\
\hline W-06 & $017-W c$ & cedrinho & faveira-amargosa & Vatairea paraensis \\
\hline W-06 & 017-Wd & cedrinho & cedrinho & Erisma uncinatum \\
\hline W-06 & $018-W$ & peroba & peroba-mica & Aspidosperma macrocarpon \\
\hline W-07 & $019-W$ & peroba & peroba-rosa & Aspidosperma polyneuron \\
\hline W-07 & $020-W$ & pinho & pinho-do-paraná & Araucaria angustifolia \\
\hline W-08 & 021-Wa & pinho & pinho-do-paraná & Araucaria angustifolia \\
\hline W-08 & $021-\mathrm{Wb}$ & pinho & cuningâmia & Cunninghamia lanceolata \\
\hline W-08 & 021-Wc & pinho & amescla & Trattinickia burseraefolia \\
\hline W-08 & $022-\mathrm{Wa}$ & peroba & angico-preto & Anadenanthera macrocarpa \\
\hline W-08 & $022-W b$ & peroba & angico-vermelho & Parapiptadenia rigida \\
\hline W-08 & $023-W$ & cedrinho & cedrinho & Erisma uncinatum \\
\hline W-08 & 024-Wa & desconhecida & angelim-pedra & Hymenolobium heterocarpum \\
\hline W-08 & 024-Wb & desconhecida & angelim-pedra & Hymenolobium heterocarpum \\
\hline W-09 & 025-Wa & pinho & pinho-do-paraná & Araucaria angustifolia \\
\hline W-09 & $025-\mathrm{Wb}$ & pinho & freijó & Cordia goeldiana \\
\hline $\mathrm{W}-10$ & 026-Wa & cedrinho & cambará & Ruizterania albiflora \\
\hline $\mathbf{W}-10$ & $026-W b$ & cedrinho & castanheira & Bertholletia excelsa \\
\hline$W-10$ & 026-Wc & cedrinho & muiracatiara & Astronium paraense \\
\hline W-10 & 026-Wd & cedrinho & cedrinho & Erisma uncinatum \\
\hline W-10 & $026-\mathrm{We}$ & cedrinho & cedrorana & Cedrelinga catenaeformis \\
\hline $\mathrm{W}-10$ & 026-Wf & cedrinho & cedrorana & Cedrelinga catenaeformis \\
\hline $\mathrm{W}-10$ & $026-\mathrm{Wg}$ & cedrinho & pinus & Pinus sp \\
\hline$W-10$ & $027-W a$ & ipê & ipê & Tabebuia sp \\
\hline $\mathrm{W}-10$ & $027-W b$ & ipê & ipê & Tabebuia sp \\
\hline $\mathrm{W}-10$ & $027-W c$ & ipê & ipê & Tabebuia sp \\
\hline$W-10$ & $027-W d$ & ipê & ipê & Tabebuia sp \\
\hline $\mathrm{W}-11$ & $028-W$ & peroba-mica & peroba-mica & Aspidosperma macrocarpon \\
\hline $\mathbf{W}-11$ & $029-W$ & $\begin{array}{l}\text { pinho-de- } \\
\text { segunda }\end{array}$ & pinus & Pinus sp \\
\hline $\mathrm{W}-11$ & $030-W$ & desconhecido & vinhático & Plathymenia foliolosa \\
\hline$W-11$ & $031-W$ & desconhecido & amescla & Trattinickia burseraefolia \\
\hline$W-11$ & $032-W$ & desconhecido & vinhático & Plathymenia foliolosa \\
\hline $\mathrm{W}-12$ & 033-W & desconhecido & ipê & Tabebuia sp \\
\hline$W-12$ & $034-W$ & desconhecido & pinho-do-paraná & Araucaria angustifolia \\
\hline$W-12$ & $035-W$ & desconhecido & ipê & Tabebuia sp \\
\hline$W-12$ & $036-\mathrm{Wa}$ & desconhecido & cedrinho & Erisma uncinatum \\
\hline$W-12$ & $036-\mathrm{Wb}$ & desconhecido & pinho-do-paraná & Araucaria angustifolia \\
\hline$W-13$ & 037-Wa & pinus & pinus & Pinus sp \\
\hline$W-13$ & $037-W b$ & pinus & pinus & Pinus sp \\
\hline$W-13$ & 037-Wc & pinus & pinus & Pinus sp \\
\hline$W-13$ & $037-W d$ & pinus & castanheira & Bertholletia excelsa \\
\hline$W-13$ & 038-Wa & cedrinho & castanheira & Bertholletia excelsa \\
\hline $\mathrm{W}-13$ & $038-W b$ & cedrinho & cedrinho & Erisma uncinatum \\
\hline
\end{tabular}




\begin{tabular}{|c|c|c|c|c|}
\hline Quest & Amostra. & Nome coletado & \multicolumn{2}{|c|}{ Identificação no laboratório } \\
\hline & & & Nome comercial & Nome científico \\
\hline W-14 & 038'-Wa & cedrinho & cambará & Qualea paraensis \\
\hline W-14 & $038^{\prime}-W b$ & cedrinho & quaruba & Vochysia vismiaefolia \\
\hline W-14 & $038^{\prime}-W c$ & cedrinho & cedrinho & Erisma uncinatum \\
\hline $\mathbf{W}-14$ & 038'-Wd & cedrinho & cedrinho & Erisma uncinatum \\
\hline W-14 & $038^{\prime}-\mathrm{We}$ & cedrinho & castanheira & Bertholletia excelsa \\
\hline W-14 & $038^{\prime}-W f$ & cedrinho & cambará & Qualea paraensis \\
\hline W-14 & $038 '-W g$ & cedrinho & angelim-pedra & Hymenolobium heterocarpum \\
\hline$W-15$ & 039-Wa & pinus & pinho-do-paraná & Araucaria angustifolia \\
\hline W-15 & $039-W b$ & pinus & pinus & Pinus sp \\
\hline W-16 & $040-\mathrm{Wa}$ & cedrinho & castanheira & Bertholletia exce/sa \\
\hline $\mathbf{W}-16$ & $040-\mathrm{Wb}$ & cedrinho & cedrinho & Erisma uncinatum \\
\hline$W-16$ & $041-W$ & peroba-amarela & guatambu-peroba & Aspidosperma populifolium \\
\hline$W-16$ & $042-W$ & pinus & pinus & Pinus sp \\
\hline W-17 & 043-Wa & pinho & pinus & Pinus sp \\
\hline $\mathbf{W}-17$ & $043-\mathrm{Wb}$ & pinho & amescla & Trattinickia burseraefolia \\
\hline $\mathbf{W}-17$ & 043-Wc & pinho & eucalipto & Eucalyptus saligna \\
\hline W-17 & $044-\mathrm{Wa}$ & cedrinho & cedrinho & Erisma uncinatum \\
\hline W-17 & 044-Wb & cedrinho & cedrinho & Erisma uncinatum \\
\hline$W-17$ & 044-Wc & cedrinho & castanheira & Bertholletia excelsa \\
\hline$W-18$ & $045-W$ & pinho & cupressus & Cupressus lusitanica \\
\hline W-18 & $046-W$ & pinus & pinus & Pinus sp \\
\hline W-18 & $047-W$ & cedrinho & cedrinho & Erisma uncinatum \\
\hline$W-18$ & 048-Wa & peroba & cupiúba & Goupia glabra \\
\hline W-18 & $048-W b$ & peroba & goiabão & Planchonella pachycarpa \\
\hline$W-19$ & $050-W$ & freijó & freijó & Cordia goeldiana \\
\hline W-19 & $051-W a$ & ipê & ipê & Tabebuia sp \\
\hline$W-19$ & $051-W b$ & ipê & ipê & Tabebuia sp \\
\hline$W-19$ & $051-W c$ & ipê & jatobá & Hymenaea courbaril \\
\hline
\end{tabular}


APÊNDICE 4 


\section{FREQÜÊNCIA DE OCORRÊNCIA DAS MADEIRAS IDENTIFICADAS}

Com vistas a detectar as madeiras mais freqüentemente identificadas nas amostras coletadas junto aos entrevistados, foi elaborada a lista abaixo onde são apresentadas as freqüências das madeiras identificadas na forma de valores percentuais em relação ao total de amostras coletadas e em relação às amostras coletadas nos distribuidores e nas construtoras.

\begin{tabular}{lccc}
\hline Nome Comercial & Distribuidores & $\begin{array}{c}\text { Freqüência (\%) } \\
\text { Construtoras }\end{array}$ & Total \\
\hline cedrinho & 12,6 & 13,9 & 13,0 \\
ipê & 8,5 & 6,6 & 7,8 \\
pinus & 4,0 & 10,7 & 6,4 \\
pinho-do-paraná & 5,4 & 6,6 & 5,8 \\
peroba-rosa & 5,8 & 4,9 & 5,5 \\
mogno & 8,1 & 0,0 & 5,2 \\
jatobá & 5,4 & 1,6 & 4,1 \\
cambará & 1,3 & 9,0 & 4,1 \\
imbuia & 5,8 & 0,0 & 3,8 \\
angelim-pedra & 3,1 & 4,1 & 3,5 \\
cerejeira & 4,5 & 0,0 & 2,9 \\
cedro & 4,0 & 0,0 & 2,6 \\
pau-marfim & 4,0 & 0,0 & 2,6 \\
garapa & 3,1 & 0,8 & 2,3 \\
cupiúba & 0,9 & 4,9 & 2,3 \\
cumaru & 3,1 & 0,0 & 2,0 \\
castanheira & 0,0 & 5,7 & 2,0 \\
freijó & 1,3 & 2,5 & 1,7 \\
peroba-mica & 1,3 & 1,6 & 1,4
\end{tabular}




\begin{tabular}{|c|c|c|c|}
\hline \multirow[t]{2}{*}{ Nome Comercial } & \multicolumn{3}{|c|}{ Freqüência (\%) } \\
\hline & Distribuidores & Construtoras & Total \\
\hline angico-preto & 1,3 & 0,6 & 1,4 \\
\hline jutai-cica & 1,8 & 0,0 & 1,2 \\
\hline cedrorana & 0,9 & 1,6 & 1,2 \\
\hline eucalipto & 0,6 & 2,5 & 1,2 \\
\hline amescla & 0,0 & 3,3 & 1,2 \\
\hline maçaranduba & 1,3 & 0,0 & 0,9 \\
\hline louro-canela & 0,9 & 0,8 & 0,9 \\
\hline muiracatiara & 0,0 & 2,5 & 0,9 \\
\hline cabreúva-vermelha & 0,9 & 0,0 & 0,6 \\
\hline itaúba & 0,9 & 0,0 & 0,6 \\
\hline sucupira & 0,9 & 0,0 & 0,6 \\
\hline cupressus & 0,6 & 0,8 & 0,6 \\
\hline faveira-amargosa & 0,6 & 0,8 & 0,6 \\
\hline goiabão & 0,6 & 0,8 & 0,6 \\
\hline quaruba & 0,6 & 0,8 & 0,6 \\
\hline angico-vermelho & 0,4 & 0,8 & 0,6 \\
\hline canafístula & 0,4 & 0,8 & 0,6 \\
\hline bacuri-de-anta & 0,0 & 1,6 & 0,6 \\
\hline cuningâmia & 0,0 & 1,6 & 0,6 \\
\hline vinhático & 0,0 & 1,6 & 0,6 \\
\hline grevílea & 0,6 & 0,0 & 0,3 \\
\hline jacareúba & 0,6 & 0,0 & 0,3 \\
\hline louro-vermelho & 0,6 & 0,0 & 0,3 \\
\hline macacaúba & 0,6 & 0,0 & 0,3 \\
\hline marinheiro & 0,6 & 0,0 & 0,3 \\
\hline marupá & 0,6 & 0,0 & 0,3 \\
\hline pau-amarelo & 0,6 & 0,0 & 0,3 \\
\hline pau-mulato & 0,6 & 0,0 & 0,3 \\
\hline piquiarana & 0,6 & 0,0 & 0,3 \\
\hline piquiá & 0,6 & 0,0 & 0,3 \\
\hline tatajuba & 0,6 & 0,0 & 0,3 \\
\hline tauari & 0,6 & 0,0 & 0,3 \\
\hline bacuri & 0,0 & 0,8 & 0,3 \\
\hline fava-orelha-de-negro & 0,0 & 0,8 & 0,3 \\
\hline faveira & 0,0 & 0,8 & 0,3 \\
\hline glícia & 0,0 & 0,8 & 0,3 \\
\hline guatambu-peroba & 0,0 & 0,8 & 0,3 \\
\hline rosadinho & 0,0 & 0,8 & 0,3 \\
\hline TOTAL $^{1}$ & 100 & 100 & 100 \\
\hline
\end{tabular}

Obs. ${ }^{1}$ Devido aos arredondamentos o total pode ser diferente de 100. 